 \\ TECHNICAL/PROFESSIONAL SERVICES
}

\section{TECHNICAL ANALYSIS OF ADVANCED WASTEWATER-TREATMENT SYSTEMS FOR COAL-GASIFICATION PLANTS}

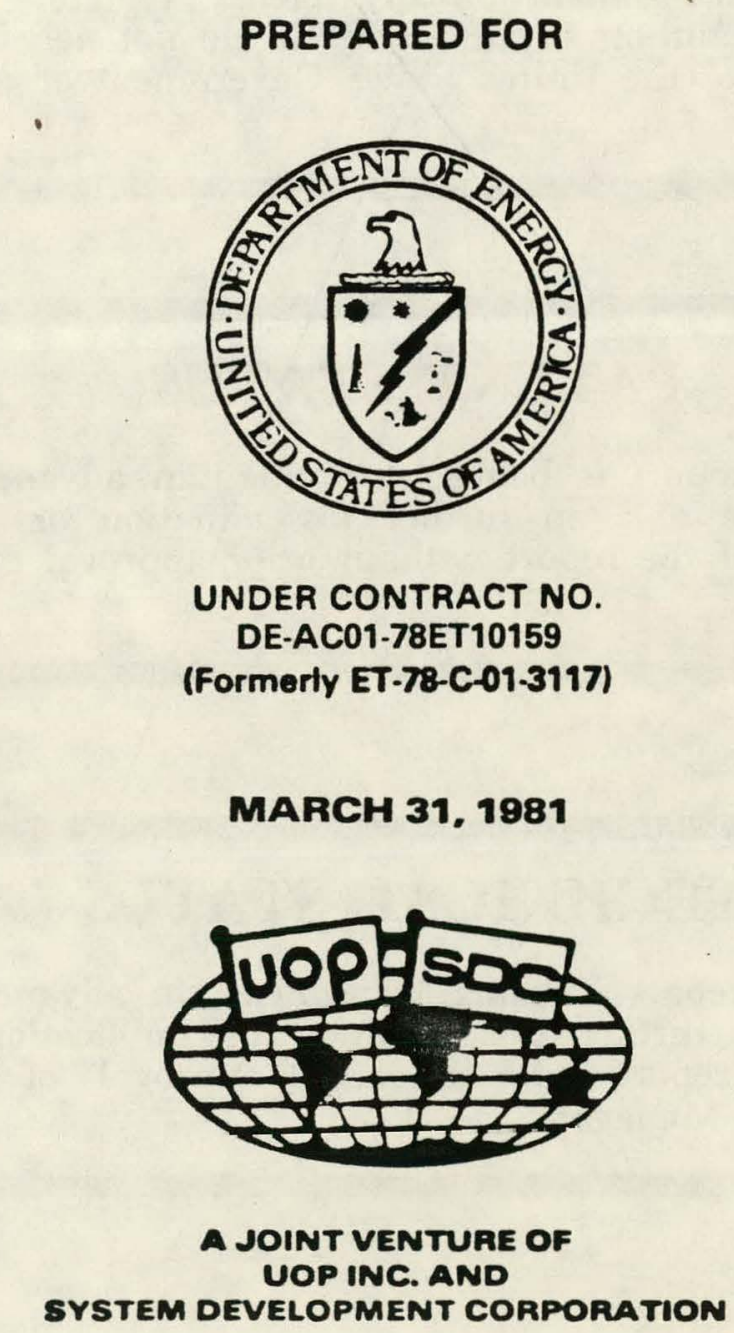




\section{DISCLAIMER}

This report was prepared as an account of work sponsored by an agency of the United States Government. Neither the United States Government nor any agency Thereof, nor any of their employees, makes any warranty, express or implied, or assumes any legal liability or responsibility for the accuracy, completeness, or usefulness of any information, apparatus, product, or process disclosed, or represents that its use would not infringe privately owned rights. Reference herein to any specific commercial product, process, or service by trade name, trademark, manufacturer, or otherwise does not necessarily constitute or imply its endorsement, recommendation, or favoring by the United States Government or any agency thereof. The views and opinions of authors expressed herein do not necessarily state or reflect those of the United States Government or any agency thereof. 


\section{DISCLAIMER}

Portions of this document may be illegible in electronic image products. Images are produced from the best available original document. 


\section{DISCLAIMER}

This report was prepared as an account of work sponsored by the United States Government. Neither the United States nor the United States Department of Energy, nor any of their employees, makes any warranty, express or implied, or assures any legal liability or responsibility for the accuracy, completeness, or usefulness of any information, apparatus, product, or process disclosed, or represents that its use would not infringe privately owned rights. Reference/herein to any specific commercial product, process, or service/by trade name, mark, manufacturer, or otherwise, does nol necessarily constitute or imply its endorsement, recommendation, or favoring by the United States Government or any/agency thereof. The views and opinions of authors expressed herein do not necessarily state or reflect those of the United States Government or any agency thereof.

This technical report is being transmitted in advance of DOE patent clearance and no further dissemination or publication shall be made of the report without prior approval of the DOE Patent Counsel.

\section{PATENT STATUS}

\section{TECHNICAL STATUS}

This technical report is heing transmitted in advance of DOE review and no further dissemination or publication shall be made of the report without prior approval of the DOE Project/Program Manager. 
TECHNICAL ANAL YSIS OF ADVANCED WASTEWATERTREATMENT SYSTEMS FOR COAL-GASIFICATION PLANTS

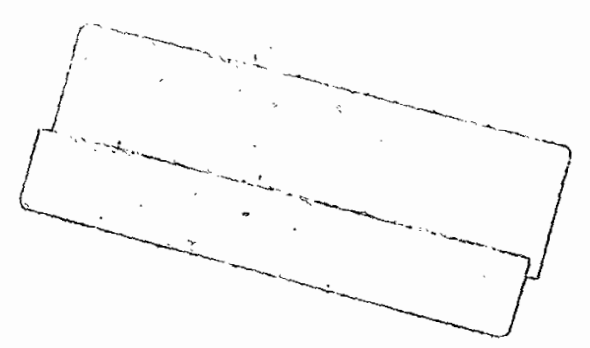

March 31, 1981

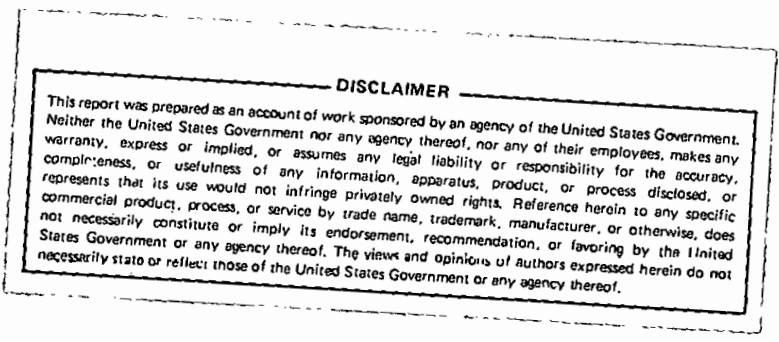

Prepared for the

United States Department of Energy

Office of Fossil Energy

Work. Performad Under

Contract No. DE-ACO1-78ET10159

(Formerly ET-78-C-01-3117)

UOP/SDC, A Joint Venture

7929 West park Drive

Mclean, Virginia 22102 


\section{EXECUT IVE SUMMARY}

This analysis of advanced wastewater treatment systems for coal gasification plants highlights the three coal gasification demonstration plants which were proposed by the U.S. Department of Energy. These are the Memphis Light, Gas and Water Division (MLGWD) Industrial Fuel Gas Demonstration Plant, the Illinois Coal Gasification Group (ICGG) Pipeline Gas Demonstration Plant, and the CONOCO Pipeline Gas Demonstration Plant.

Technical risks exist for coal gasification wastewater treatment systems, in general, and for the three DOE demonstration plants (as designed), in particular, because of key data gaps. The quantities and compositions of coal gasification wastewaters are not well known; the treatability of coal gasification wastewaters by various technologies has not been adequately studied; the dynamic interactions of sequential wastewater treatment processes and upstream wastewater sources has not been tested at demonstration scale.

This report identifies the key data gaps and recommends that demonstration-size and commercial-size plants be used for coal gasification wastewater treatment data base development. While certain advanced treatment technologies can benefit from additional bench-scale studies, bench-scale and pilot plant scale operations are not representative of commercial-size facility operation. It is recommended that coal gasification demonstration plants, and other commercial-size facilities that generate similar wastewaters, be used to test advanced wastewater treatment technologies during operation by using sidestreams or collected wastewater samples in addition to the plant's own primary treatment system.

Advanced wastewater treatment processes are needed to degrade refractory organics and to concentrate and remove dissolved solids to allow for wastewater reuse. Further study of reverse osmosis, evaporation, electrodialysis, ozonation, act ivated carbon, and ultrafiltration should take place at bench-scale. 
TABLE OF CONTENTS

\section{SECTION}

PAGE

INTRODUCT ION

CHARACTERIZATION OF COAL GASIFICATION WASTEWATERS

2.1 Introduction

2.2 Description of Coal Gasification Wastewater

2.3 Sources of Wastewater Contaminants

2.4 Pilot Plant Data

3.2 Industry Experience

3.3 Data Gaps

3.4 Design Considerations

4

$$
\text { INDUSTRIAL WASTEWATER TREATMENT PROCESSES }
$$

4.1 Introduction

4.2 Treatment Process Descriptions

4.3 Effluent Standards and Approved Instrumental Methods

GASIFICATION DEMONSTRATION PLANT WASTEWATER TREATMENT SYSTEM ANALYSES

5.1 Introduction

5.2 ICGG Pipeline Gas Demonstration Plant

5.3 CONOCO Pipeline Gas Demonstration Plant

5.4 MLGWU Industrial Fueí Gas Uemonstration plant 
TABLE

PAGE

2.1

Classification of Coals According to Rank

2-2

2.2

Composition of Pretreatment Scrubber Water

$2-8$

2.3

Equilibrium Concentrations of Elements in

Typical Coal Ash Leachate

Coal Composition

Nitrogen Containing Byproducts of Coal Gasification (1b/1000 Ib MAF coal)

Trace Element Concentrations in Coal

Distribution of Hazardous Trace Elements in Coal (ppm)

Leachate from Lurgl (Ury) Ash

Characteristics of Waste Extracts Using the RCRA

$$
\text { Extraction Procedure }
$$

Typical Byproduct Wastewater Concentrations from a Synthane Gasifier

Characteristics of SASOL Wastewaters 


\section{LIST OF TABLES (Cont'd)}

$\underline{T A B L E}$

PAGE

2.18

Characteristics of $\mathrm{CO}_{2}$-Acceptor Gasifier

Quench Condens ate

2.19

Characteristics of Wastewaters from Bi-Gas

Pilot Plant Operation

Characteristics of Cogas (COED Section) Raw Gas Quench Condensate

2.21 Characteristics of Decanter Water Samples from METC/DOE Gasifier

Texaco Coal Analyses

Texaco Analyses Trace Components

Texaco Water Quality Data Eastern Coal

Texaco Water Quality Western Coal

2.26

Texaco Trace Elements in Water Streams Eastern Coal

Texaco Trace Elements in Water Streams Western Coal

3.1

Compositions of Effluent Gases from Gasifiers and Coke Ovens

3.2

Composition of Wastewaters from Gasifiers and Conking.

Operating Data from Pilot Plant Activated Sludge Units Processing Raw Coke Plant Weak Ammonia Liquor (WAL)

Coke Plant Wastewater Influent Concentrations and Act ivated Carbon Removal Efficiencies 


$$
\text { LIST OF TABLES (Cont'd) }
$$

TABLE

PAGE

4.1

Wastewater Effluent Regulations

State Wastewater Effluent Standards Daily Maximum Concentrations

Estimated Influent Concentrations to Equalization Tank

\section{LIST OF FIGURES}

FIGURE

PAGE

ICGG Wastewater Treatment Plant Flow Diagram 
UOP/SDC, A Joint Venture, is providing technical analyses of treatment systems for coal gasification wastewaters to the U.S. Department of Energy (DOE). These analyses include identification of what is known and what is unknown about available and emerging treatment technology for gasification wastewaters. Detailed analyses of the technical risks associated with the treatment systems designed for three demonstration plants are provided in this report. These analyses are intended to assist the DOE's assessment and mitigation of the technical risks associated with wastewater treatment for commercial coal gasification plants, in general, and for the three designed DOE demonstration plants (MLGWD, CONOCO, and ICGG), in particular.

Earlier studies by Water Purification Associates included analyses of water conservation and wastewater treatment for a variety of coal conversion technologies.1,2 These two studies highlighted the water conservation and wastewater reuse needs of coal conversion plants in the western U.S. The analyses in this UOP/SDC report provide an update and expansion of this earlier data base on wastewater treatment technologies. The principal focus of the report is on the general needs of coal gasification plants and the particular needs of the three proposed DOE gasification demonstration plants.

Wastewater treatment technology for coal gasiification plants faces the challenge of increased regulatory attention to potentially hazardous contaminants and to achieving maximum water reuse. Coal gasification wastewaters are for biologically hazardous polynuclear organics and metal ion complexes. At the same time, maximum water reuse is being promoted as a way to avoid pollutant discharges and to conserve water resources. Processes for the destruction or degradation of refractury urganics and for the separation (and concentration for disposal) of highly soluble strong electrolytes will be needed for treating coal gasification wastewaters. 
A typical coal gasification plant consumes large quantities of water for cooling and steam generation. Both of these operations normally result in some evaporative water loss. Condensate from these operations, along with wastewaters from such other operations as coal preparation and raw gas cleaning, can be treated for reuse or for discharge. The degree of treatment necessary for these wastewaters is influenced by water availability, local discharge regulations, and the costs of equipment and system operation. The design of treatment systems begins with an assessment of the volume and degree of contamination of various process and non-process wastewater streams.

The composition and quantity of process wastewaters are determined by the composition of coal feed and the conditions of the gasification processes. Generally, the higher the temperature of the reactor vessel and the longer the coal is in the reactor, the cleaner the wastewaters are. High-sulfur coals, such as eastern U.S. coals, generally yield more highly contaminated wastewaters. Nonprocess wastewaters are characterized by coal type, plant layout and design, type of coal storage, and climatic factors. Open coal storage, in particular, is a significant wastewater source during rainstorms.

The design criteria for gasification plant wastewater treatment systems are affected by the degree of wastewater reuse that is desired. In general, the treatment for tars/oils, suspended solids, dissolved organics, and other contaminants such as ammonia does not depend upon wastewater reuse plans. A major difference, however, can occur if individual process wastewater streams are treated independently for particular reuse applications. This would contrast with wastewater treatment systems designed for the discharge of treated wastewater. Systems designed for discharge usually combine most process and stormwater runoff wastewater streams after minimal pretreatment. This single-train treatment of the combined wastewater streams provide the beneficial effects of buffering, dilution, and economy-of-scale.

The most significant challenge facing a treatment system designed for wastewater reuse, as contrasted with one designed for wastewater discharge, is the separation and concentration of dissolved solids. Conventional wastewater 
treatment systems precipitate some dissolved contaminants, but the highly soluble strong electrolytes are normally discharged with the treated wastewater effluent. Concentrations of these strong electrolytes will quickly build up to unacceptable levels unless they are removed from reused wastewaters. Removal of highly soluble strong electrolytes requires the use of somewhat unconventional wastewater treatment technologies, such as reverse osmosis, electrodialys is, and evaporation.

The characteristics of the wastewaters generated by various coal gasification plant process sources and stormwater runoff sources are presented in Section 2. The effectiveness of the various wastewater treatment technologies is analyzed in the review of treatability studies in Section 3. Data gaps in wastewater characteristics and treatability are included at the ends of Sections 2 and 3 , respectively. Section 4 of this report describes conventional and unconventional technologies available, or potentially available, for treating gasification wastewaters to meet discharge regulations or reuse requirements. A short. subsection on approved instrumental methods is included.

The three demonstration plants are the subject of Section 5 . The designed MLGWD, CONOCO, and ICGG demonstration plants are described and their wastewater treatment systems are analyzed. Section 6 presents the conclusions of these technical analyses of advanced wastewater treatment systems for coal gasification plants. Recommendations for eliminating data gaps are presented in Section 7 . 
SECTION 2 - CHARACTERIZATION OF COAL GASIFICATION WASTEWATERS

\subsection{INTRODUCTION}

Coal gasification facilities generate wastewaters with contaminant levels far exceeding acceptable limits for discharge or direct reuse. The following section describes the major sources and compositions of wastewaters from gasification facilities. This is a general discussion because the level of pollutants will vary, depending on the type of coal being used and the gasification process employed. A discussion of the origin and distribution of the major pollutants associated with gasification wastewaters is presented. The last section summarizes the data from pilot plant operation and discusses the scalability of that data to demonstration-size and commercial-size facilities.

\subsection{DESCRIPTION OF COAI. GASIFICATION WASTEWATERS}

The sources, quantities, and compositions of coal gasification wastewaters vary according to the gasification process used and the type of coal gasified. The variability of coal composition is shown in Table 2.1. The temperatures and pressures at which gasification processes takes place also affect the composition of the product gases evolved. As the product gas is quenched, water carrying soluble components is condensed from the raw gas. Quench condensate is the largest process wastewater stream and has the potential to be the most cont aminated.

Increasing the operating pressure of the gasification reaction results in higher methane concentrations, which increases the heating value of the product gas. Carbon monoxide and hydrogen production is decreased with increasing pressure. Organic by-products shift to higher molecular weights as the pressure increases.

Increasing the gasifier reaction temperatures shifts the equilibrium constants and increases the reaction rates of the principal conversion processes. Elevated gasification temperatures result in cleaner wastewaters because of thermal cracking of phenols, oils, tars and other hydrocarbons. Low-temperature gasification 
Táble 2.1 Classification of Coals According to Rank ipage 1 of 2)

Anthracite

\begin{tabular}{|c|c|c|c|c|c|c|c|c|}
\hline Class & Location & Seam & $\begin{array}{c}\text { Equil ibrium } \\
\text { Moisture }\end{array}$ & $\begin{array}{c}\text { Volatile } \\
\text { Matter }\end{array}$ & $\begin{array}{l}\text { Fixed } \\
\text { Carbon }\end{array}$ & Ash & Sulfur & $\begin{array}{l}\text { Btu/lb } \\
\text { (MAF) }\end{array}$ \\
\hline $\begin{array}{l}\text { Anthracite } \\
\text { Meta-Anth. }\end{array}$ & $\begin{array}{l}\text { Pa. } \\
\text { Schulykill }\end{array}$ & - & $4.5 \%$ & $1.7 \%$ & $34.1 \%$ & $9.7 \%$ & $0.77 \%$ & 12,745 \\
\hline Anthracite & $\begin{array}{l}\text { Pa. } \\
\text { Lackawanna }\end{array}$ & - & $2.5 \%$ & $6.2 \%$ & $79.4 \%$ & $11.9 \%$ & $0.6 \%$ & 12,925 \\
\hline
\end{tabular}

$\stackrel{n}{n}$

Bituminous.

\begin{tabular}{|c|c|c|c|c|c|c|c|c|c|}
\hline$\underset{B}{H i g h}$ & $\begin{array}{l}\text { Volatile } \\
\text { Bit. }\end{array}$ & I11. & $\# 6$ & $5.8 \%$ & $36.2 \%$ & $46.3 \%$ & $11.7 \%$ & $2.7 \%$ & 11,910 \\
\hline$\underset{C}{H i g h}$ & $\begin{array}{l}\text { Volatile } \\
\text { Bit. }\end{array}$ & $\begin{array}{l}\text { \#Ill. } \\
\text { Graene Co. } \\
\text { *Ohino } \\
+K y \text {. }\end{array}$ & $\begin{array}{l}\# 5 \\
\# 9 \\
\# 9\end{array}$ & $\begin{array}{r}7.2 \% \\
2.5 \% \\
11.0 \%\end{array}$ & $\begin{array}{l}41.8 \% \\
35.0 \% \\
35.4 \%\end{array}$ & $\begin{array}{l}48.0 \% \\
40.0 \% \\
41.6 \%\end{array}$ & $\begin{array}{l}10.2 \% \\
22.5 \% \\
12.0 \%\end{array}$ & $\begin{array}{l}3.9 \% \\
6.3 \% \\
2.8 \%\end{array}$ & $\begin{array}{l}12,610 \\
14,560 \\
11,157\end{array}$ \\
\hline$\underset{B}{\mathrm{High}}$ & $\begin{array}{l}\text { Vol. } \\
\text { Bit. }\end{array}$ & $\begin{array}{l}\# \mathrm{~Pa} \text {. } \\
\text { Greene Co. }\end{array}$ & $\# 8$ & $2.5 \%$ & $35.4 \%$ & $54.4 \%$ & $10.0 \%$ & $2.6 \%$ & 13,670 \\
\hline
\end{tabular}

\# Coal used in ICGG Demonstration Plant Design.

* Coal used in COڤOCO Demonstration Plant Design.

+ Coal used in Merphis Fuel Gas Plant Design.

Reference 3 (P 5-15, Table 21) 
Tatie 2.1 Classification of Coals According to Rank

(page 2 of 2 )

Sub-Bituminous

\begin{tabular}{|c|c|c|c|c|c|c|c|c|}
\hline Class & Location & Seam & $\begin{array}{l}\text { Equilibrium } \\
\text { Moisture }\end{array}$ & $\begin{array}{c}\text { Volatile } \\
\text { Matter }\end{array}$ & $\begin{array}{l}\text { Fixed } \\
\text { Carbon } \\
\end{array}$ & Ash & Sulfur & $\begin{array}{l}\text { Btu/lb } \\
\text { (MAF) }\end{array}$ \\
\hline Sub-Bit. A & $\begin{array}{l}\text { Musselshell } \\
\text { Co., Mont. }\end{array}$ & - & $14.1 \%$ & $32.2 \%$ & $46.7 \%$ & $7.0 \%$ & $0.43 \%$ & 11,140 \\
\hline Sub-Bit. B & $\begin{array}{l}\text { Sher idan Co., } \\
\text { Wyoming }\end{array}$ & - & $25.0 \%$ & $30.5 \%$ & $40.8 \%$ & $3.7 \%$ & $0.30 \%$ & 9,345 \\
\hline Sub-Bit. C & $\begin{array}{l}\text { Campbell Co., } \\
\text { Wyoming }\end{array}$ & - & $31.0 \%$ & $31.4 \%$ & $32.8 \%$ & $4.8 \%$ & $0.55 \%$ & 8,320 \\
\hline & & & & & ignite & & & \\
\hline Lignite A & $\begin{array}{l}\text { Mercer Co., } \\
\text { No. Dakota }\end{array}$ & - & $37.0 \%$ & $26.6 \%$ & $32.2 \%$ & $4.2 \%$ & $0.4 \%$ & 7,255 \\
\hline
\end{tabular}


results in wastewaters higher in hydrocarbons. Dilution of these wastewaters may be required prior to treatment.

High-Btu gas production results in other wastewaters from shift conversion, methanation, and other gas enrichment processes. Other wastewater streams are coal-dependent, both in source and composition. The pretreatment of caking coals contributes wastewaters from quenching the pretreatment off-gases.

The major sources of wastewaters from gasification plants are:

- Coal pile runoff

- Coal preparation

- Coal pretreatment

- Ash quench

- Gas quench

- Shift condensation

- Methanation condensation

- Cooling tower blowdown

- Process area runoff

- Sanitary sewage

- Plant drains

In this section, the identification of wastewater sources and characteristics is based upon a generic demonstration-size facility.

\subsubsection{Coal Pile Runoff}

Coal storage is necessary to maintain a constant feed of coal to the gasifier and to allow continued operation during interruptions in coal supply. Storage is divided between live storage and dead storage. Live storage is coal used during normal operation. Dead storage is coal which can be used during interruptions in coal supply when live storage is depleted. Storage methods used for coal vary with the type of coal. Higher-rank coals can be stored in larger piles and stored longer because they oxidize more slowly than low-ranking coal. Higher-rank eastern U.S. coals can be stored longer than lower-rank western 
U.S. coals because of this reactivity difference. Finer ground coal has a shorter storage life because the higher surface-to-volume ratio increases oxidation rates. Demonstration-size facilities require as much as 125,000 tons of coal for 90-day storage. The area required for this amount of open storage - about 8 to 10 acres - can intercept a large quantity of water during a storm. The stormwater will penetrate the pile and leach the coal unless a crusting materlal is used to seal the coal pile. Water, being a polar solvent, dissolves oxidized pyritic minerals in the coal and forms sulfuric acid and ferrous sulfate. Many types of metals and other compounds are leached into solution by the secondary reactions of sulfuric acid with the coal.

The amount of sulfuric acid in coal pile runoff is highly dependent upon the sulfur content of the coal being stored. In general, about $50 \%$ of the sulfur content of coal is in the form of pyrite, particularly when the sulfur content of coal is high. Eastern U.S. bituminous coals have sulfur contents ranging from $3 \%$ to over $6 \%$. Western U.S. sub-bituminous and lignite coals generally have sulfur contents under $0.5 \%$. It is expected that the runoff from piles of eastern U.S. bituminous coal will be of $1 \mathrm{OW} \mathrm{pH}$ and high in dissolved solids and metals, whereas the western U.S. coal run off should have a runoff of near neutral pH and low levels of dissolved solids. The actual pH of runoff will also depend on the duration of storage between storms.

The mineral content of the coal determines the composition and concentrations of the elements that leach from the coal. Mineral components of coal include $\mathrm{SiO}_{2}, \mathrm{Al}_{2} \mathrm{O}_{3}, \mathrm{TiO}_{2}, \mathrm{Fe}_{2} \mathrm{O}_{3}, \mathrm{CaO}, \mathrm{MgO}, \mathrm{Na}_{2} \mathrm{O}$, and $\mathrm{K}_{2} \mathrm{O}$. Under acidic conditions, a portion of the metals dissolves. Leaching is expected to be slower for lowsulfur coals because of the higher $\mathrm{pH}$ of the runoff.

Coals with higher sulfur content will have a higher sulfate content and a lower pH iil llie runoff for equivalent storage duration and weather conditions. Runoff wastewaters from high-sulfur coals are high in dissolved solids, including $\mathrm{Al}, \mathrm{Ca}, \mathrm{Mg}, \mathrm{K}, \mathrm{Si}, \mathrm{Na}, \mathrm{Fe}, \mathrm{Mn}$, and $\mathrm{Zn}$ in concentrations above $1.0 \mathrm{mg} / \mathrm{l}$. Runoff from subbituminous or lignite coals has a $\mathrm{pH}$ close to neutral and low levels of dissolved solids. 
Neutral pH runoff low in dissolved solids can also occur for high sulfur coal that has been treated with crusting materials. Crusting materials are sprayed on the outer surface of coal piles to prevent stomwater from penetrating the pile. The crusting materials form a barrier to water causing stormwater to run off without leaching oxidized pyrites.

All exposed coal storage facilities should have provisions for collection of stormwater runoff. This is usually accomplished by storing coal on an impervious surface. Runoff is intercepted and conveyed to temporary storage. This wastewater, which can be either treated directly or combined with other wastewater streams, is usually neutralized prior to treatment to prevent treatment process upsets and equipment deterioration.

Because they occur only intermittently, storm runoff wastewaters are usually treated in facilities used primarily for other wastewater streams. Initial treatment, after neutralization, includes dilution and softening followed by precipitation or coagulation-flotation. The choice of the treatment process depends upon the intended disposition of this wastewater. Mixing of runoff wastewater with other water may dilute dissolved solids to concentrations suitable for cooling tower makeup water. Direct reuse of runoff wastewaters is not. widespread, however, because it is usually necessary to treat the runoff wastewater before it can be recycled to the cooling tower. Furthermore, cer-' tain contaminants in the runoff wastewater may not be acceptable in the cooling tower makeup because they will be released into the air with the cooling tower drift.

Chemical treatment of stormwater runoff to increase the $\mathrm{pH}$ and decrease suspended and dissolved solids is expected to be the most cost effective. Softening-flotation or softening-sedimentation processes usirig lime or NoOll and polymer coagu= lation aids can be used to reduce the concentrations of dissolved and suspended solids. Addition of small amounts of lime $\left(\mathrm{Ca}(\mathrm{OH})_{2}\right)$ to the runoff precipitates sulfates as insoluble $\mathrm{CaSO}_{4}$. Use of additional lime precipitates insoluhle metal hydroxides. At a $\mathrm{pH}$ above 6 , aluminum is precipitated as $\mathrm{Al}(\mathrm{OH})_{3}$. As the addition of lime causes the $\mathrm{pH}$ to rise from 6 to 9 , iron is precipitated as 
$\mathrm{Fe}(\mathrm{OH})_{3}$, lead is precipitated as $\mathrm{Pb}(\mathrm{OH})_{3}$, and zinc precipitated as $\mathrm{Zn}(\mathrm{OH})_{2}$. As the $\mathrm{pH}$ rises above 10, nickel, mercury, and magnesium precipitate as $\mathrm{Ni}(\mathrm{OH})_{2}$, $\mathrm{Hg}(\mathrm{OH})_{2}$, and $\mathrm{Mg}(\mathrm{OH})_{2}$, respectively. Calcium originally present in the wastewater and from added lime precipitates as $\mathrm{CaCO}_{3}$ if the alkalinity is high enough. $\mathrm{Na}_{2} \mathrm{CO}_{3}$ is added to increase the $\mathrm{CO}_{3}=$ concentration if the alkalinity is too low.

Removal of dissolved metal cations by the use of lime softening can be $70 \%$ to 90\% effective. The precipitates formed can be removed to concentrations of 100 to $500 \mathrm{mg} / 1$ by sedimentation or flotation. As the $\mathrm{pH}$ of the decanted water is adjusted back towards neutral, the precipitates that carry over redissolve. If higher metal removals are desired, filtration of the decanted water prior to neutralization can be used to reduce the concentration of the insoluble precipitates in the water to 5 to $20 \mathrm{mg} / 1$. These concentrations should be suitable for water reuse, but not for discharge. Additional treatment, such as reverse osmosis and/or evaporation, is necessary to purify the water to discharge quality.

The solids precipitated by lime softening are metal hydroxides, sulfates, and carbonates. These materials may require disposal in a sealed landfill under the new Resource Conservation and Recovery Act (RCRA) guidelines. The possibility of these material's leaching into groundwater systems must be minimized.

\subsubsection{Coal Preparation}

Coal preparation and handling at gasification facilities include all the steps required to transfer coal from live storage to gasifier coal feed systems. Coal preparation involves crushing, sizing, washing, and drying.

Coal preparation and handling can generate substantial amounts of wastewater from coal washing and dust control. Water consumption for coal washing can be as high as 1500 to 2000 gallons per ton of coal processed. Stormwater falling on coal preparation and handling areas will generate a wastewater similar to coal pile runoff. 


\subsubsection{Coal Pretreatment}

Pretreatment to destroy caking tendencies is needed to gasify most eastern U.S. coals in fluidized-bed or fixed-bed reactors. Untreated caking coals in fluidized-bed gasifiers operated above $800^{\circ} \mathrm{F}$ can form lumps that interrupt the fluidizing gas streams, causing bed collapse. The lumps formed in fixed-bed gasifiers agglomerate into large masses that prevent the proper flow of hot gases through the bed.

Caking coals are normally pretreated in fluidized bed reactors operated at telluperalures too low for caking to occur. Steam and oxygen or air are injected into the bed to partially oxidize the coal surface, forming a non-sticky surface. Pretreatment is not required for some mildly caking coals or for coals slurried with water or light product oil for feeding into entrained-flow gasifiers.

Coal pretreater off-gases are scrubbed with water. Because the temperature at which pretreatment takes place is relatively low, the pretreatment gases are high in phenols, tars, aromatics, and other organic pollutants. These materials are scrubbed out of the gas and are thus in the wastewater from the scrubber. Scrubber wastewater composition depends upon coal composition. Typical concentrations are shown in Table 2.2 .

Table 2.2 Composition of Pretreatment Scrubber Water

\begin{tabular}{cc} 
Material & $\frac{\mathrm{mg} / \mathrm{l}}{700-1060}$ \\
\hline TSS & $870-1200$ \\
TOC & $23-26$ \\
$\mathrm{NH}_{3}$ & 1330 \\
Phenol & $2600-4800$ \\
TDS & $159-239$ \\
0 il \& Grease & $2-3$ \\
$\mathrm{~S}^{=}$ & $209-316$ \\
$\mathrm{SCN}^{-}$ & $.003-.024$ \\
$\mathrm{CN}^{-}$ &
\end{tabular}


Treatment of pretreater wastewater is similar to treatment of the product gas quench condensate, which is discussed in a later section. Pretreatment and gasification are similar processes that produce similar types of wastewaters; the combination of these wastewaters for treatment is not expected to pose any problems in treatability of the wastewater.

\subsubsection{Ash Quench Water}

Coal gasification ash can be classified into two distinct types, lignite and bituminous. Lignite-type ash characteristically contains more $\mathrm{CaO}$ and MgO than $\mathrm{Fe}_{2} \mathrm{O}_{3}$. This ash is found in most western U.S. coals. Eastern U.S. coals have bituminous-type ash that contains more $\mathrm{Fe}_{2} \mathrm{O}_{3}$ than $\mathrm{MgO}$ and $\mathrm{CaO}$. Most of the minerals present in the coal appear in the ash.

Ash generated during coal gasification exits in two ways. Small particles are entrained in the product gas and recovered in downstream equipment. Most of the ash, however, is removed from the bottom of the reactor. Steps :must be taken to preserve the pressure within the reactor during ash withdrawal and to recover sensible heat from the ash being removed. Pressure can be maintained in the reactor during withdrawal through the use of lockhoppers.

Ash can be removed from the gasifier in two forms, dry or as slag. The determining factor is the reaction bed temperature. At temperatures in the bed above $2000^{\circ} \mathrm{F}$, the ash exists as molten slag.

As the ash/slag leaves the gasifier and drops into the quench hopper, it is rapidly cooled by contact with water. Slag, as it hits the water, shatters into small fragments. Heat from the ash/slag is recovered from the quench water in heat exchangers. The water is then separated from the ash/slag and recycled back to ash/slag quench. Makeup quench water is required to replace water lost as steam and with the wet solids.

Ash/slag quench water is high in suspended solids and relatively high in dissolved solids and $\mathrm{pH}$. Concentrations of ammonia, sulfides, and organics are low. The presence of $\mathrm{CaO}, \mathrm{MgO}, \mathrm{Na}_{2} \mathrm{O}$, and $\mathrm{K}_{2} \mathrm{O}$ in the ash/slag causes the $\mathrm{pH}$ 
of the quench water to rise to 8 to 12 . Most heavy metals, such as $\mathrm{Zn}, \mathrm{Cd}, \mathrm{Pb}$, and $\mathrm{Cr}$, have low dissolved concentrations at these $\mathrm{pH}$ levels. Some elements, such as $\mathrm{Se}, \mathrm{As}, \mathrm{F}$, and $\mathrm{B}$, which can exist as anions under alkaline conditions, can be present at significant dissolved concentrations. A sample tabulation of equilibrium element concentrations in coal ash leachate is shown in Table 2.3.

Recycled ash/slag quench water requires blowdown to reduce the dissolved solids to acceptable levels. The blowdown stream is nomally mixed with other wastewater streams for treatment. The addition of carbonates to this high TDS wastewater removes some of the dissolved solid through precipitation. At elevated $\mathrm{pH}$, carbonate compounds of many dissolved metals precipitate and can be removed by filtration, flotation, or sedimentation.

Sludges generated by these treatment processes must be tested for leachability by RCRA-mandated extraction procedures. Wastes determined to be hazardous under RCRA regulations will require special disposal.

\subsubsection{Raw Gas Quench Water}

The hot product gas stream from the gasifier must be cooled before acid gas removal. The gas is quenched to reduce its temperature and to remove entrained particulates and water soluble gaseous impurities. Water is sprayed through the $r$ aw gas in the quench operation. A downstream waste heat boiler recovers heat by condensing the steam in the raw gas and the steam from evaporation of the quench water.

Raw gas quench water is the largest and the most contaminated wastewater stream generated in a gasification facility. The composition of the product gas directly influences the composition of the quench water. Many by-products and impurities in the product gas, namely ammonia, phenol, tars and oils, are readily condensed during the quench operation. Some of the acid gases, such as $\mathrm{H}_{2} \mathrm{~S}$ and $\mathrm{CO}_{2}$, are dissolved in the quench water. Steam condensate from the waste heat boilers also contains water-soluble impurities from the product gas. 
Table 2.3 Equilibrium Concentrations of Elements in Typical Coal Ash Leachate

Element

$\mathrm{Sb}$

As

$\mathrm{Ba}$

$\mathrm{Be}$

B

Cd

$\mathrm{Cr}$

$\mathrm{Cu}$

$F$

$\mathrm{Ge}$

$\mathrm{Hg}$

$\mathrm{Pb}$

$\mathrm{Mn}$

Mo

$\mathrm{Ni}$

Se

$v$

$\mathrm{Zn}$

$\mathrm{pH}$

\# derived from Reference 1 (P27)
Leachate Concentrations\#

(mg/l)

0.017

0.036

0.3

0.001

3.65

0.003

0.292

0.031

4.88

0.01

0.0003

0.008

0.002

0.167

0.12

0.103

0.01

0.055

10.9 
Raw gas quench waters from fluidized-bed or entrained-bed gasifiers are highly particulate laden. Fixed-bed processes have lower particulate levels in the quench water.

Gasifiers that operate in the low-temperature, dry-ash mode have a significant amount of organic contaminants in the raw gas quench water. High-temperature gasifiers have quench waters of much lower organic pollutant loads because the elevated temperatures cause the oils, tars, and phenols to crack into simpler compounds.

Raw gas quench water undergoes phenol and ammonia removal before being blended with other wastestreams for further treatment. Phenol removal precedes ammonia removal because the solvents used to extract phenol do not remove ammonia, whereas ammonia removal processes may also remove phenol, thus making it difficult to recover both phenol and ammonia for sale. The reduction of phenols to sublethal concentrations is necessary before downstream biological treatment.

Two separate wastewater streams can be generated if a two-stage raw gas quench is employed. 5 In this case, the strong electrolytes will dissolve in the initial quenchwater, wich will be of a lower discharge volume than the secondstage quench. The latter will remove the weak electrolytes, such as phenols and other soluble organics. The greater part of the raw gas temperature drop will also take place on the second-stage quench. The production of two quench water blowdown streams of distinctly different composition would be advantageous only if these two streams were treated separately for reuse in the gasification plant.

\subsubsection{Shift Condensate}

The product gas from the gasifier typically has only a medium Btu content. Therefore, for a high Btu product, the quenched gas must undergo a shift reaction before methanation to adjust the hydrogen to carbon monoxide rat10 to $3: 1$. Water containing contaminants condenses when the shifted gas cools. Gases present in the condensate include $\mathrm{H}_{2} \mathrm{~S}$ and $\mathrm{CO}_{2}$. The condensate may also contain 
contaminants similar to those in the raw gas quench water, but at lower concentrations.

Since treatment of these wastewaters is similar to the treatment of raw gas quench water, these two waste streams can be combined before treatment.

\subsubsection{Methanation Condensate}

The final upgrading step to produce pipeline quality gas is methanation. Water formed during methanation is free of dissolved and suspended solids and gases and is therefore suitable for direct reuse.

\subsubsection{Cooling Tower Blowdown}

The blowdown from cooling towers in gasification facilities should be similar in composition to other cooling tower blowdowns. This wastewater will be very high in dissolved solids and other inorganic and organic materials. The exact composition and concentrations will depend upon the tower operation and the quality of the make-up water.

Before treatment, cooling tower blowdown can be diluted with other wastewaters that are much lower in dissolved solids. If treated wastewaters are used for cooling tower makeup, removal of dissolved solids is necessary to prevent a buildup of dissolved solids in the recycled flow. The entire cooling tower blowdown can also be treated separately and reused as makeup water. The processes available for dissolved solids removal include evaporation and reverse osmosis.

The composition of recycled water in cooling towers must be controlled so that the cumpusition of cooling tower drift does not adversely affect downwind air quality. It is especially important that the concentrations of chemicals with known adverse health effects be kept below hazardous levels in the cooling tower drift. 


\subsubsection{Process Area Runoff}

Gasification process area stormwater runoff must be collected and treated before discharge or reuse. The runoff from a gasification facility should be similar to that from such industrial plants as petroleum refineries. Runoff may be fairly high in suspended solids and oils.

Treatment of this wastewater begins with the separation of solids and oils. The separated wastewater effluent can be reused in process areas if TDS and organics levels are not too high. Otherwise, it would nomally be blended with other wastewaters for further treatment.

\subsubsection{Sanitary Sewage}

The sanitary sewage generated by the employees at a gasification facility can be treated separately or mixed with process wastewaters. Mixing is appropriate only if the process wastewaters can be treated by biological oxidation, which is the most efficient and reliable method of treatment of sanitary sewage. Since wastewater is normally disinfected by chlorination, it should not be combined with other wastewater streams for treatment if toxic chlorinated hydrocarbons will be produced from the latter by chlorination.

\subsubsection{Plant Drains}

There are numerous drains throughout the plant where miscellaneous wastewaters are discharged and collected. The quantity and composition of these wastewaters depends on plant layout and design.

\subsection{SOURCES OF WASTEWATER CONTAMINANTS}

This section describes the origin of wastewater contaminants formed during gasification. The composition of the coal being gasified is a major factor in the quantity and composition of the wastewaters eventually produced. The operating conditions under wich gasification takes place also determine the amount and 
forms of contaminants. Table 2.4 gives the composition of the organic portion of different coals; the remaining fraction is ash.

Compounds formed in coal gasification from the elements in Table 2.4 are phenols, ammonia, cyanides, thiocyanates, and hydrogen sulfides. These compounds constitute the majority of the weak electrolytes produced during gasification.

Most inorganics in coal remain as ash or slag when coal is gasified. The elements comprising the ash are those typically found in minerals, namely silicon, alumi num, iron, and calcium, with smaller amounts of sodium, titanium, magnesium, and potassium. The concentrations of the various oxides of these elements in four coal types are shown in Table 2.5.

\subsubsection{Phenol, Tar, and $0 i 1$}

There are two distinct stages in coal carbonization. The first occurs at $750-950^{\circ} \mathrm{F}$, when the coal becomes plastic. At temperatures in excess of $1200^{\circ} \mathrm{F}$, the coal begins to decompose. As the temperature rises, the volatile components of the coal begin to be released from the coal. As these products pass through the coal. or coke, they initiate secondary reactions with the less volatile components and produce tar. Tar is composed of light and heavy hydrocarbons, nitrogen aromatics, and oxygen-containing molecules.

Hydrocarbons produced range from single ring benzene to multiple ring structures. Nitrogen aromatics include pyridines, picalines, and quinolines. The oxygen aromatics are phenol-based compounds, such as phenol, cresol, xylenol, and naphthol. These products account for a large fraction of the organic loading in gasification wastewaters.

The amount and characteristics of the tar removed from the raw gas stream depend upon the coal type and the operating conditions within the gasifier. Any changes in gasifier operating conditions that reduce the organic loading to the quench water also reduce the treatment required for the condensate stream. 
Table 2.4 Coal Composition

COAL

CARBON HYDROGEN SULFUR OXYGEN
(all values in weight-percent)

Bituminous

I11. \#6

$\mathrm{Ky}$. \#9

Pitt. \#8

Sub-Bituminous

Montana

Rosebud

Wyoming

Lignite

N. Dakota

Peat

N.C. Humus

63.26

67.36

5.37

5.58

72.29

3.45

53.95

6.87

56.8

5.94

0.59

0.55

28.53

30.02

1.20

0.38

8.86

6.31

46.82

9.45

0.56

35.63

0.73

6.81

30.22

5.34

0.12

59.84

0.81

3.67

Reference 6 (P5, Table 1) 
Table 2.5 Inorganic Components of Coal Ash

\begin{tabular}{|c|c|c|c|c|c|c|c|c|c|}
\hline RANK & $\% \mathrm{SiO}_{2}$ & $\% \mathrm{Al}_{2} \mathrm{O}_{3}$ & $\% \mathrm{Fe}_{2} \mathrm{O}_{3}$ & $\% \mathrm{TiO}_{2}$ & $\% \mathrm{CaO}$ & $\% \mathrm{MgO}$ & $\% \mathrm{Na}_{2} \mathrm{O}$ & $\% \mathrm{~K}_{2} \mathrm{O}$ & $\% \mathrm{SO}_{3}$ \\
\hline Anthracite & $25-68$ & $25-44$ & $2-10$ & $1.0-2.0$ & $0.2-4.0$ & $0.2-1$ & - & - & $0.1-1$ \\
\hline Bituminous & $7-68$ & $4-39$ & $2-44$ & $0.5-4.0$ & $0.7-36$ & $0.1-4$ & $0.2-3$ & $0.2-4$ & $0.1-32$ \\
\hline Sub-Bituminous & $17-58$ & $4-35$ & $3-19$ & $0.6-2.0$ & $2.2-52$ & $0.5-8$ & - & - & $3-16$ \\
\hline Lignite & $6-40$ & $4-27$ & $1-34$ & $0.0-0.8$ & $12.4-52$ & $2.8-14$ & $0.2-28$ & $0.1-13$ & $8 \cdot 3-32$ \\
\hline
\end{tabular}

Reference 7 (P广, Table 2) 
Tars, oils, and phenols are also be produced during coal pretreatment. The below $800^{\circ} \mathrm{F}$ conditions of pretreatment do not favor the cracking of organic compounds evolved during the process. At these low temperatures, the evolved gases contain high concentrations of tars, heavier oils, and phenols.

Review of phenol and tar production in different gasification processes reveals that tar and phenol production is reduced at elevated temperatures. This is due to the instability of aromatic rings at temperatures in excess of $1400^{\circ} \mathrm{F}$. Thermal cracking converts aromatic molecules to straight chain molecules. This phenomenon is the reason why the higher temperature slagging Lurgi process produces lower amounts of tars and phenols than the cooler dry ash Lurgi process.

Tar and phenol production from gasifiers can also be reduced by altering the physical configuration of the gasifier. For a Synthane gasifier, the tar and phenol production was significantly reduced when the coal was injected deep into the fluidized bed. 8 The normal method of introducing coal into the gasifier is to allow it to fall through the rising hot gases. Feeding the coal deeper into the bed reduces the production of tars and phenols partially because the bed temperatures exceed the temperature of the hot gases and partially because of the longer reaction time.

It was found 8 that extending the residence time of the tars or pyrolization gases within the gasifier reduced the amount of tars and phenols evolved. Residence time was found to be optimum at between two and four seconds for the gasifier configuration and the reaction conditions of the study.

At a constant residence time in the Synthane gasifier, phenol conversion increased with increasing temperature to a maximum of about $1800^{\circ} \mathrm{F}$. At a temperature of $1800^{\circ} \mathrm{F}$, the phenol reduction was over $99 \%$. The gasifier that appears to have the least organics production is the Koppers-Totzek, which operates at $2700^{\circ} \mathrm{F}$ with a gas residence time of a few seconds. In it, the tars, oils, and phenols are converted into smailer compounds. 
The influence of the above factors on tar and phenol production is illustrated in Table 2.6, wich gives the composition of quench waters from various gasifiers. The $\mathrm{CO}_{2}$-Acceptor process is one of the cleanest processes shown. The very low tar and phenol production is due to high temperature and long residence time of the product gas in the gasifier. Operation is at $1500^{\circ} \mathrm{F}$ with at least 25 seconds of residence time in the bed plus another 30 seconds in a disengaging zone above the bed. The combination of these two conditions effectively reduces the production of tars and phenols to very low levels.

As would be expected, low-temperature gasifiers have high tar and phenol production. In the dry ash Lurgi process, the coal is devolatized above the bed rather than in the bed. This results in the evolution of gases at a temperature of about $900^{\circ} \mathrm{F}$. The cogas process has aqueous effluents that are high in organics. This again is due to the low temperatures in the first pyrolizers, where the more volatile components are evolved. Under low-temperature conditions, the conversion of tars and phenols does not take place.

The operating conditions of the Hygas gasifier result in negligible production of tars but significant production of oils and phenols. Devolatization takes place at high temperatures $\left(1200^{\circ} \mathrm{F}\right)$ but the residence time in the gasifier is only about one second. In this case, the high temperature in the reactor reduces the heavier tars to lighter oils and phenols. The oils produced in this process are lighter than oils from Lurgi or Synthane gasifiers. Hygas oils are composed primarily of benzene, toluene, and xylene.

Comparison of organics production from a Lurgi and a Hygas gasifier makes it possible to draw some conclusions about the influence of operating conditions on the organics composition in quench condensates. The temperature at which the devolatization gases exist determines the nature of the organics produced. Raising the temperature causes the heavier compounds to crack into smaller compounds. The conversion of the light oils and phenols cannot be effectively accomplished by high temperatures alone. The gases must exist at the high temperature long enough for the conversion reactions to take place. 
Table 2.6 Organics Produced in Gasification Processes

(1b/1000 Ib MAF)

\begin{tabular}{|c|c|c|c|c|c|c|}
\hline Process & Coal & $\begin{array}{l}\text { Con } \\
\text { Or } \\
\text { Tar }\end{array}$ & $\begin{array}{l}\text { able } \\
\text { cs } \\
0 i 1\end{array}$ & TOC & COD & Phenol \\
\hline $\begin{array}{l}\mathrm{CO}_{2} \\
\text { Acceptor }\end{array}$ & $\begin{array}{l}\text { N.D. } \\
\text { Lignite }\end{array}$ & None & None & 0.04 & 0.8 & 0.003 \\
\hline Hygas & $\begin{array}{l}\text { Montana } \\
\text { Lignite }\end{array}$ & None & 85 & 20 & NR & 0.00 \\
\hline & $\begin{array}{l}\text { Montana } \\
\text { Sub-Bitumi. }\end{array}$ & None & 125 & 5 & NR & 8 \\
\hline & $\begin{array}{l}\text { I11. " } \\
\text { Bituminous }\end{array}$ & None & NR & 14 & NR & 6 \\
\hline Lurgi & $\begin{array}{l}\text { Montana } \\
\text { Sub-Bit. }\end{array}$ & 30 & 30 & NR & 28 & 8 \\
\hline (Dry Ash) & $\begin{array}{l}\text { I11. \#6 } \\
\text { Bit. }\end{array}$ & 30 & 5 & NR & 26 & 6 \\
\hline & $\begin{array}{l}\text { I11. \#5 } \\
\text { Bit. }\end{array}$ & 40 & 7 & NR & 22 & 6 \\
\hline & $\begin{array}{l}\text { Pitts. \#8 } \\
\text { Bit. }\end{array}$ & 40 & 9 & NR & 15 & 4 \\
\hline $\begin{array}{l}\text { Slagging } \\
\text { Gasifier }\end{array}$ & $\begin{array}{l}\text { N.D. } \\
\text { Lignite }\end{array}$ & \multicolumn{2}{|c|}{ [37] } & 8 & NR & NR \\
\hline Cogas & $\begin{array}{l}\text { I11. \#6 } \\
\text { Bit. }\end{array}$ & \multicolumn{2}{|c|}{$[160]$} & $N \bar{R}$ & NR & 20 \\
\hline Synthane & I71. \#6 & \multicolumn{2}{|c|}{ [37] } & NR & 8 & \\
\hline (Free Fall) & $\begin{array}{l}\text { Montana } \\
\text { Sub-Bit. }\end{array}$ & NR & NR & NR & 10 & 1.3 \\
\hline $\begin{array}{l}\text { Teep Bed } \\
\text { Injection) }\end{array}$ & $\begin{array}{l}\text { Montana } \\
\text { Sub-Bit. }\end{array}$ & NR & NR & NR & 10 & 1.3 \\
\hline $\begin{array}{l}\text { Koppers } \\
\text { Totzek }\end{array}$ & $\begin{array}{l}\text { S. Africa } \\
\text { Bit. }\end{array}$ & None & None & Negligible & $16 \mathrm{mg} / 1$ & Negligible \\
\hline
\end{tabular}

NR = Not Reported

[]$=$ combination of tar and oil

Reference 9 


\subsubsection{Nitrogen Compounds}

The nitrogen content of coal is about 1\%. Nitrogen released during coal pretreatment and coal gasification reacts in these reducing atmospheres to form ammonia, cyanides, and thiocyanates, rather than oxides of nitrogen. Table 2.7 shows the nitrogen-containing byproducts formed in different gasifiers.

About $80 \%$ of the nitrogen present in coal is converted to gaseous nitrogen, ammonia, cyanide, and other nitrogen-based compounds during gasification. It is believed that ammonia results from reaction of nitrogen with amino side chains within the volatile components of coal. Nitrogen remaining with the char is usually incorporated into multi-ring compounds that are much more refractory than the amino side chains. The presence of hydrogen in gasification results in more ammonia production than under normal carbonization conditions.

The Koppers-Totzek process produces the least ammonia, the Lurgi and Synthane processes produce the most. Other than the fact that the $K-T$ process uses an .. entrained bed and operates at much higher temperatures, there are not many data that can account for the differences in ammonia production between these gasification processes.

The production of cyanide is caused by secondary reactions and is enhanced by high temperatures. Cyanide has not been observed to be produced from gasifying coal at low temperatures. Cyanide has been formed by pyrolizing nitrogen-containing organics, notably pyridine. Data necessary to provide more detailed information on cyanide production are not available.

The formation of thiocyanate in coal gasifiers is documented but is not understood. Thiocyanate is present in significant quantities in quench condensates. It is thought that the thiocyanate concentrations in quench waters are a result of aqueous reactions involving cyanide and various sulfur compounds in the presence of oxygen. Quench water has been found to increase in thiocyanate concentrations while decreasing in cyanide concentrations with time. 
Table 2.7 Nitrogen-Containing Byproducts of Coal Gasification (1b/1000 ib MAF coal)

\begin{tabular}{|c|c|c|c|c|}
\hline Process & Coal & $\mathrm{NH}_{3}$ & $\mathrm{CN}^{-}$ & $\mathrm{SCN}^{-}$ \\
\hline $\mathrm{CO}_{2}$-Acceptor & $\begin{array}{l}\text { N. Dakota } \\
\text { Lignite }\end{array}$ & 12 & 0.014 & 0.06 \\
\hline Hygas & $\begin{array}{l}\text { Montana Lignite } \\
\text { Montana Sub-Bit. } \\
\text { I11. \#6 Bit. }\end{array}$ & $\begin{array}{r}15 \\
7 \\
9\end{array}$ & $\begin{array}{l}0.001 \\
0.001 \\
0.001\end{array}$ & $\begin{array}{l}1.2 \\
0.5 \\
5\end{array}$ \\
\hline $\begin{array}{l}\text { Lurgi } \\
\text { (Iiry Ash) }\end{array}$ & $\begin{array}{l}\text { Montana Sub. Bit. } \\
111 . \# 6 \text { Bit. } \\
111 . \# 5 \text { Bit. } \\
\text { Pitts. "8 Bit. }\end{array}$ & $\begin{array}{l}6 \\
8 \\
8 \\
8\end{array}$ & $\begin{array}{l}0.005 \\
0.02 \\
0.01 \\
0.01\end{array}$ & $\begin{array}{l}0.06 \\
0.15 \\
0.18 \\
0.26\end{array}$ \\
\hline $\begin{array}{l}\text { Slagging } \\
\text { Gasifier }\end{array}$ & $\begin{array}{l}\text { No. Dakota } \\
\text { Lignite }\end{array}$ & 4 & NR & NR \\
\hline Cogas & 111. \#6 Bit. & $N R$ & NR & NR \\
\hline Synthane & 111. \#6 Bit. & 8 & None & 0.01 \\
\hline (Free Fall) & $\begin{array}{l}\text { Montana } \\
\text { Sub-Bit. }\end{array}$ & 1.2 & NR & NR \\
\hline (Deep Bed) & $\begin{array}{l}\text { Montana } \\
\text { Sub-Bit. }\end{array}$ & 1.8 & NR & NR \\
\hline $\begin{array}{l}\text { Koppers } \\
\text { Totzek }\end{array}$ & & Negligible & NR & NR \\
\hline
\end{tabular}


Most nitrogen compounds produced during coal gasification are soluble in water and are removed during raw gas quench. These nitrogen compounds must be reduced to concentrations that are non-lethal to microorganisms prior to biological processes, if these are used to treat the wastewater. Various removal methods can be employed; the final removal of low concentrations may be accomplished by biological oxidation.

\subsubsection{Trace and Minor Elements}

A great deal of research has been done to identify and quantify the ways that trace elements can be released by the gasification of coal. Almost every element can be found in coal. To simplify this analysis, only those elements that have been recognized as being hazardous are discussed. These elements are arsenic (As), cadmium (Cd), chromium $(C r)$, copper $(C u)$, iron (Fe), mercury ( $\mathrm{Hg})$, manganese $(\mathrm{Mn})$, nickel $(\mathrm{Ni})$, lead $(\mathrm{Pb})$, tin $(\mathrm{Sn})$, and zinc $(\mathrm{Zn})$.

Trace elements are naturally occurring. In fact, most of these elements are necessary for the proper functioning of biological systems. The quantity and chemical form of each element are the controlling factors for determining relative hazards. "Trace" elements occur in concentrations less than 1000 ppm in the earth's crust. "Minor" elements are those that are present in concentrations exceeding 1000 ppm. Table 2.8 shows the ranges in concentrations for various trace elements in coal.

The trace elements shown in Table 2.9 are of particular importance because their presence in a different chemical form or in higher concentrations than found in coal can be hazardous to plant and animal life. These elements can be volatilized and converted to more hazardous forms in coal gasification. Ash and slag produced during gasification also wil? contain higher concentrations of materials that are not volatilized.

Elements that are volatilized or partially volatilized during gasification are arsenic, cadmium, and mercury. All these elements are at least 50\% volatilized. Transition metals, such as iron and nickel, may be volatilized as carbonyls. 
Table 2.8 Trace Element Concentrations in Coal

\begin{tabular}{ccccc} 
Element & Mean & Max. & Min. & Std. Dev. \\
\hline As & 14.02 & (values in ppm) & \\
$\mathrm{Cd}$ & 2.52 & 93 & 0.5 & 17.7 \\
$\mathrm{Cr}$ & 13.75 & 54 & 0.1 & 7.6 \\
$\mathrm{Cu}$ & 15.16 & 61 & 4.0 & 7.26 \\
$\mathrm{Hg}$ & 0.20 & 1.6 & 0.02 & 8.12 \\
$\mathrm{Mn}$ & 49.4 & 181.0 & 6.0 & 0.20 \\
$\mathrm{Ni}$ & 21.07 & 80 & 3.0 & 40.15 \\
$\mathrm{~Pb}$ & 34.78 & 218 & 4.0 & 12.35 \\
$\mathrm{Sn}$ & 4.79 & 51 & 1.0 & 43.69 \\
$\mathrm{Zn}$ & 272.29 & 5,350 & 6 & 6.15
\end{tabular}

Reference 10 (P 2-35) 


\section{Table 2.9 Distribution of Hazardous Trace Elements in Coal (ppm)}

\begin{tabular}{|c|c|c|c|}
\hline Element & West Interior & Eastern Interior & Appalachiar \\
\hline Ant imony & 3.5 & 1.3 & 1.2 \\
\hline Arsenic & 16 & 14 & 18 \\
\hline Beryllium & 2 & 1.8 & 2.0 \\
\hline Cadmium & 20 & 2.3 & 0.2 \\
\hline Mercury & 0.13 & 0.19 & 0.16 \\
\hline Lead & NR & 34 & 12 \\
\hline Selenium & 5.7 & 2.5 & 5.1 \\
\hline Zinc & NR & 250 & 13 \\
\hline
\end{tabular}


Arsenic is found in tar and raw gas quench water; mercury and cadmium are predominantly associated with tar. The percentage of the original volatile elements carried over with the raw gas increases with increasing gasifier temperatures.

The remaining trace elements remain with the ash or slag removed from the gasifier. The solid slag or ash is separated from the ash quench water and disposed in a landfill. The current regulations of the Resource Conservation and Recovery Act (RCRA) provide procedures for determining the degree of hazard due to leaching. Any material that is immersed in water at a pH of 5.0 for 24 hours and shows a concentration of an element that is 100 times that of the drinking water standard is considered hazardous and subject to all RCRA regulations.

Ash from a dry-ash Lurgi gasifier using Mercer County and Dunn County, North Dakota, lignite was leached at the University of North Dakota. The results are shown in Table 2.10. Leaching in this case was done by crushing the ash and refluxing it for 16-24 hours with boiling demineralized water. The leachate obtained is expected to be more concentrated than normal landfill leachate because the crushed ash has more surface area than normal ash and the boiling water should increase the solubilities of the elements. Ashes from a Lurgi gasifier, a Wellman-Galusha gasifier, and a Texaco gasifier were subjected to the RCRA Extraction Procedure test.11 The results are given in Table 2.11. These leachate tests indicate that these ashes would not be classified as hazardous wastes under RCRA.

\subsection{PILOT PLANT DATA}

Most wastewaters from coal gasification have been obtained from experimental or developmental facilities. These bench and pilot scale facilities are not necessarily representative of commercial-scale facilities. A cumicrctal-scale plant, in general, has wastewater flows that do not have counterparts in the smaller-scale facilities. In some instances, however, a wastewater stream will be generated by the pilot plant that is representative of the commercial scale process. 


\section{Table 2.10 Leachate from Lurgi (Dry) Ash}

\begin{tabular}{|c|c|c|c|}
\hline \multirow[b]{2}{*}{ Element } & \multicolumn{2}{|c|}{ Leachate (ug/l) } & \multirow{2}{*}{$\begin{array}{r}\text { RCRA Stand } \\
(u \mathrm{~g} / 1)\end{array}$} \\
\hline & Mercer Co. & Dunn Co. & \\
\hline Arsenic & 3000 & 45 & 5000 \\
\hline Cadmium & 700 & 10 & 1000 \\
\hline Chromium & 70 & 200 & 5000 \\
\hline Copper & 50 & 300 & - \\
\hline Mercury & NR & 2 & 200 \\
\hline Manganese & 6 & 120 & - \\
\hline Nickel & 9 & 50 & - \\
\hline Lead & 7 & 20 & 5000 \\
\hline $\operatorname{Tin}$ & 3 & NR & - \\
\hline zinc & 20 & 30 & - \\
\hline
\end{tabular}

+100 times of primary drinking water standards

$N R=$ Not reported

Reference 12 (P5) 
Tatile 2.11 Characteristics of Waste Extracts Using the RCRA Extraction Procedure

\begin{tabular}{|c|c|c|c|c|c|c|c|c|c|c|c|c|c|c|}
\hline & \multicolumn{14}{|c|}{ Concentration, $4 \mathrm{~g} / 1$} \\
\hline & $\mathrm{Ag}$ & As & $\mathrm{Ba}^{\star}$ & $\mathrm{Cd}$ & $\mathrm{Cr}$ & $\mathrm{Hg}$ & $\mathrm{Pb}$ & Se & $\mathrm{B}^{\star}$ & $\mathrm{Cu}$ & $M n^{\star}$ & $\mathrm{Ni}$ & $U^{\star}$ & $2 n^{\star}$ \\
\hline $\begin{array}{l}\text { Lurgi-Rosebud } \\
3 / 8^{\prime \prime}-20 \text { mesh } \\
20-100 \text { mesh } \\
>100 \text { mesh }\end{array}$ & $\begin{array}{l}<0.2 \\
<0.2 \\
<0.2\end{array}$ & $\begin{array}{r}<1 \\
2 \\
3\end{array}$ & $\begin{array}{l}0.5 \\
1.0 \\
2.3\end{array}$ & $\begin{array}{r}<0.1 \\
1.1 \\
2.0\end{array}$ & $\begin{array}{l}<6 \\
<6 \\
<6\end{array}$ & $\begin{array}{l}<0.4 \\
<0.4 \\
<0.4\end{array}$ & $\begin{array}{r}<0.2 \\
1.0 \\
1.8\end{array}$ & $\begin{array}{l}\vdots 1 \\
\vdots 1 \\
\vdots 1\end{array}$ & $\begin{array}{l}0.55 \\
1.48 \\
1.85\end{array}$ & $\begin{array}{r}2.7 \\
5.4 \\
13.3\end{array}$ & $\begin{array}{l}3.22 \\
5.83 \\
9.25\end{array}$ & $\begin{array}{r}34 \\
80 \\
138\end{array}$ & $\begin{array}{l}<0.5 \\
<0.5 \\
<0.5\end{array}$ & $\begin{array}{l}0.124 \\
0.157 \\
0.321\end{array}$ \\
\hline $\begin{array}{c}\text { Lurgi-Il linois } \$ 5 \\
3 / 8 "-20 \text { mesh } \\
20-100 \text { mesh } \\
>100 \text { mesh }\end{array}$ & $\begin{array}{r}<0.2 \\
<0.2 \\
\vdots .5\end{array}$ & $\begin{array}{r}<1 \\
<1 \\
3\end{array}$ & $\begin{array}{r}<0.2 \\
0.8 \\
1.0\end{array}$ & $\begin{array}{l}52 \\
32 \\
26\end{array}$ & $\begin{array}{l}5 \\
3 \\
4\end{array}$ & $\begin{array}{l}<0.4 \\
<0.4 \\
<0.4\end{array}$ & $\begin{array}{l}0.9 \\
3.1 \\
4.4\end{array}$ & $\begin{array}{r}1 \\
\vdots 1 \\
3\end{array}$ & $\begin{array}{l}0.28 \\
0.77 \\
0.49\end{array}$ & $\begin{array}{l}5.6 \\
6.5 \\
5.1\end{array}$ & $\begin{array}{l}0.39 \\
1.15 \\
2.50\end{array}$ & $\begin{array}{r}4240 \\
442 \\
441\end{array}$ & $\begin{array}{l}<0.5 \\
<0.5 \\
<0.5\end{array}$ & $\begin{array}{r}37.1 \\
28.5 \\
9.2\end{array}$ \\
\hline $\begin{array}{c}\text { Lurgi-Il linois } \# \text { } \\
3 / 8 "-20 \text { mesh } \\
20-100 \text { mesh } \\
>100 \text { mesh }\end{array}$ & $\begin{array}{r}0.9 \\
1.4 \\
<0.2\end{array}$ & $\begin{array}{r}4 \\
<1 \\
<1\end{array}$ & $\begin{array}{l}<0.2 \\
<0.2 \\
<0.2\end{array}$ & $\begin{array}{r}13 \\
5.1 \\
4.3\end{array}$ & $\begin{array}{r}3 \\
3 \\
<2\end{array}$ & $\begin{array}{l}<0.4 \\
<0.4 \\
<0.4\end{array}$ & $\begin{array}{l}1.3 \\
1.3 \\
1.6\end{array}$ & $\begin{array}{l}3 \\
\vdots 1 \\
\therefore i\end{array}$ & $\begin{array}{l}0.04 \\
0.25 \\
0.20\end{array}$ & $\begin{array}{l}<2 \\
<2 \\
<2\end{array}$ & $\begin{array}{l}0.28 \\
0.39 \\
0.71\end{array}$ & $\begin{array}{l}49 \\
56 \\
72\end{array}$ & $\begin{array}{l}<0.5 \\
<0.5 \\
<0.5\end{array}$ & $\begin{array}{l}4.27 \\
2.84 \\
1.13\end{array}$ \\
\hline $\begin{array}{l}\text { Wel Iman-Galusha, } \\
\text { ash }\end{array}$ & $<1$ & 19 & 1.0 & $<7$ & 1 & $<0.6$ & 7 & 14 & -- & -- & -- & -- & -- & -- \\
\hline $\begin{array}{l}\text { Wel Iman-Galusha, } \\
\text { dust }\end{array}$ & $<1$ & 33 & 1.0 & $<1$ & 1 & $<0.3$ & 8 & 6 & -- & -- & -- & -- & -- & -- \\
\hline Texaco, slag & $<2$ & $<2$ & 0.19 & 37 & 4 & $<0.2$ & $<2$ & $\therefore 1$ & -- & -- & -- & -- & -- & -- \\
\hline $\begin{array}{l}\text { Boiler bottom } \\
\text { ash }\end{array}$ & $<I$ & $<1$ & 0.28 & $<0.3$ & $<3$ & $<0.2$ & $<3$ & :1 & -- & -- & -- & -- & -- & -- \\
\hline Boiler fly ash & 2 & 5 & 0.44 & 5.3 & 16 & $<0.2$ & $<3$ & 2 & -- & -- & -- & -- & -- & -- \\
\hline $\begin{array}{l}\text { 100x primary } \\
\text { drinking water } \\
\text { standard }\end{array}$ & 5030 & . $\quad 5000$ & 100 & $100 \mathrm{C}$ & 5000 & 200 & 5000 & 1300 & -- & -- & -- & -- & -- & -- \\
\hline
\end{tabular}

*Values in mg/l

Reference 11,13 
The mode of operation of bench and pilot scale plants also makes it difficult to gather samples that are representative of commercial-scale wastewaters. A commercial plant can maintain essentially steady-state operating conditions. However, bench and pilot scale operations are characterized by wide variations as the optimum gasification conditions are determined. The materials and equipment used in these gasifiers have been subject to failures as the process develops. These failures usually cause a process shutdown. The incorrect selection of process parameters for a gasifier run may also result in process failure. When a steady state condition within the gasifier cannot be achieved, wastewater sampling cannot be representative of a commercial-scale facility.

Pilot plants may also be significantly different from commercial plants in matters other than scale. Often they are not complete plants or are comprised of somewhat different process units. Pilot plants may gasify a variety of coals as the process limitations are investigated. The data obtained during these experimental runs may not be representative of a commercial facility because the operating conditions and the coal being gasified are different. These differences can be critical because wastewater constituents are sensitive to coal type and operating conditions.

Data collection to determine and optimize treatment processes for the wastewaters from coal gasifiers is not unlike the development of the process itself. The gasification process and the wastewater treatment system must evolve at the same time. When the process is ready for commercial-scale operation, the wastewater treatment system operating parameters must have been determined.

The data from pilot and commercial gasification plants are discussed below. Scalable wastewater streams found in the pilot plant studies are identified and characterized.

\subsubsection{Synthane}

The Synthane process, which is presently mothballed, had been studied ${ }^{14}$ to determine the characteristics of the largest wastewater stream, the quench 
condensate. This condensate is approximately $95 \%$ water, with the remainder being mostly ammonia and phenols. Tars also condense out with the steam.

Characteristics of the raw gas quench waters for different coals are shown in Table 2.12. This table shows that the quench wastewater is highly contaminated, regardless of the type of coal gasified. Western U.S. coals (Wyoming and North Dakota) result in the most contaminated quench waters. COD, tar, and phenol concentrations in the Synthane quench water have been significantly reduced by injecting the coal into the fluidized bed rather than having it fall onto the bed. Deep bed injection subjects the initial gasification products to much higher temperatures and provides a longer residence time. As a result, tars are reduced by $60 \%$ and phenols by more than half.

\subsubsection{Lurgi}

The Lurgi process is one of the few gasification processes that is operating worldwide at commercial scale. The commercial plants in operation are primarily the dry ash type. Modifications of the dry ash process to gasify caking American coals are at the pilot stage of development. The most promising type is the fixed bed, slagging type (British Gas). Advantages of the slagging process include increased efficiency, reduction of aqueous pollutants, and ability to use caking U.S. coals. Extensive studies have been done on the effluents from both the dry ash and slagging Lurgi processes.

The largest water stream generated by a dry ash Lurgi gasifier is the raw gas condensate. This stream also contains most of the pollutants associated with the process. Because of these two factors, this stream is the most intensively investigated at the commercial facilities in operation. Gasification of U.S. coals has been investigated at the Lurgi facilities at. Westfield, Scotland, and at the SASOL plant in South Africa. Coals tested at Westfield were Montana Rosebud, Illinois \#5, Illinois \#6, and Pittsburgh \#8. Tests performed at SASOL used Texas lignite. The purpose of these tests was to determine the modifications to the Lurgi process necessary for the gasification of predominantly caking U.S. coals. 
Table 2.12 Typical Byproduct Wastewater Concentrations From A Synthane Gasifier*

\begin{tabular}{|c|c|c|c|c|c|c|c|}
\hline & $\begin{array}{l}\text { Coke } \\
\text { Plant } \\
\end{array}$ & $111 . \# 6$ & Wyoming & $\begin{array}{l}\text { N.D. } \\
\text { Lignite }\end{array}$ & $\begin{array}{c}\text { West Ky. } \\
\text { Bit. }\end{array}$ & $\begin{array}{c}\text { Pitts. } \\
\text { Bit. }\end{array}$ & $\begin{array}{c}\text { Montana Rosebud } \\
\text { Sub-Bit. } \\
\end{array}$ \\
\hline $\mathrm{pH}$ & 9 & 8.6 & 8.7 & 9.2 & 8.9 & 9.3 & 9.2 \\
\hline $\begin{array}{l}\text { Suspended } \\
\text { Solids } \\
\end{array}$ & 50 & 600 & 140 & 64 & 55 & 23 & 68 \\
\hline Phenol & 2,000 & 2,600 & 6,000 & 6,600 & 3,700 & 1,700 & 3,000 \\
\hline TOC & - & 6,800 & - & - & - & 4,980 & 9,090 \\
\hline $\mathrm{COD}$ & 7,000 & 15,000 & 43,000 & 38,000 & 19,000 & 19,000 & 22,000 \\
\hline Ammonia & 5,000 & 8,100 & 9,500 & 7,200 & 10,000 & 11,000 & 9,500 \\
\hline Thiocyanate & 1,000 & 152 & 23 & 22 & 200 & 188 & 31 \\
\hline Cyanide & 100 & 0.6 & 0.23 & 0.1 & 0.5 & 0.6 & 0.07 \\
\hline Tar & - & 71,600 & - & 27,800 & - & - & 23,000 \\
\hline
\end{tabular}

* A1l values in PPM except $\mathrm{PH}$ Reference 15 ( $P 5$, Table 1) 
The raw wastewater is processed for tar and oil removal, phenol extraction, and ammonia removal. The resulting stream is referred to as processed wastewater. The processed wastewater is usually treated further to reduce organic and inorganic pollutants. Table 2.13 shows the characteristics of the raw and processed wastewaters obtained by Fleeker ${ }^{16}$.

Most contaminants in the raw wastewater were removed in the tar and oil removal, phenol extraction, and ammonia removal. It should be noted that the analyses were obtained from single samples of the raw wastewater and the processed wastewater. The ages of the samples were not accurately known, but the raw wastewater was less than six months old and the processed wastewater was less than a month old. Analyses were completed within four months of receipt. Samples were stored after receipt at $4^{\circ} \mathrm{C}$. The effects of sample age are unknown. These data are for information purposes only, because of the statistically small data base.

Wastewater data from the gasification of U.S. coals at Westfield, Scotland, have also been collected. The data were collected from each of the two wastewater streams leaving the tar/oil separator. The overflow goes with the oils to additional oil removal, while the bottoms stream is conveyed with the tar for further separation. Table 2.14 gives the values formed for both these streams during gasification of U.S. coals.

A review of the data shows that both streams for all coals are heavily contaminated. Comparing the heavier tar stream to the lighter oil stream reveals that there is usually a slightly higher BOD and COD in the lighter oil fraction and a much higher free-ammonia content. The heavier tar fraction had a higher $\mathrm{pH}$, a higher TDS content, and a lower cyanide and thiocyanate concentration. These two streams undergo separate tar and oil removal and are then combined and treated further for phenol, ammonia, and organics removal.

These data were obtained from a commercial gasifier, making scaleup of various process streams unnecessary. The drawback of the dry ash Lurgi process was that large quantities of excess steam were required to prevent the formation of clinkers within the gasifier. The large amount of steam rendered the process 
Table 2.13 Characteristics of SASOL Wastewaters\#

\begin{tabular}{lcc} 
Parameter & Raw Wastewater & \multicolumn{2}{c}{ Processed Wastewater } \\
\cline { 2 - 3 } COD & 12,500 & 1,330 \\
TOC & 4,190 & ND \\
TDS & 2,460 & 596 \\
PH & 8.9 & 8.2 \\
Fatty Acids & 226 & 194 \\
Phenols & 2,360 & 3.2 \\
Aromatic Amines & 219 & 0.45 \\
Ammonia & 11,200 & 150
\end{tabular}

\footnotetext{
\# all values in $\mathrm{mg} / \mathrm{l}$, except $\mathrm{pH}$ ND $=$ not determined

Reference 16 (P2, 12-14)
} 
Table 2.14 Characteristics of Lurgi Dry Ash Condensates\#

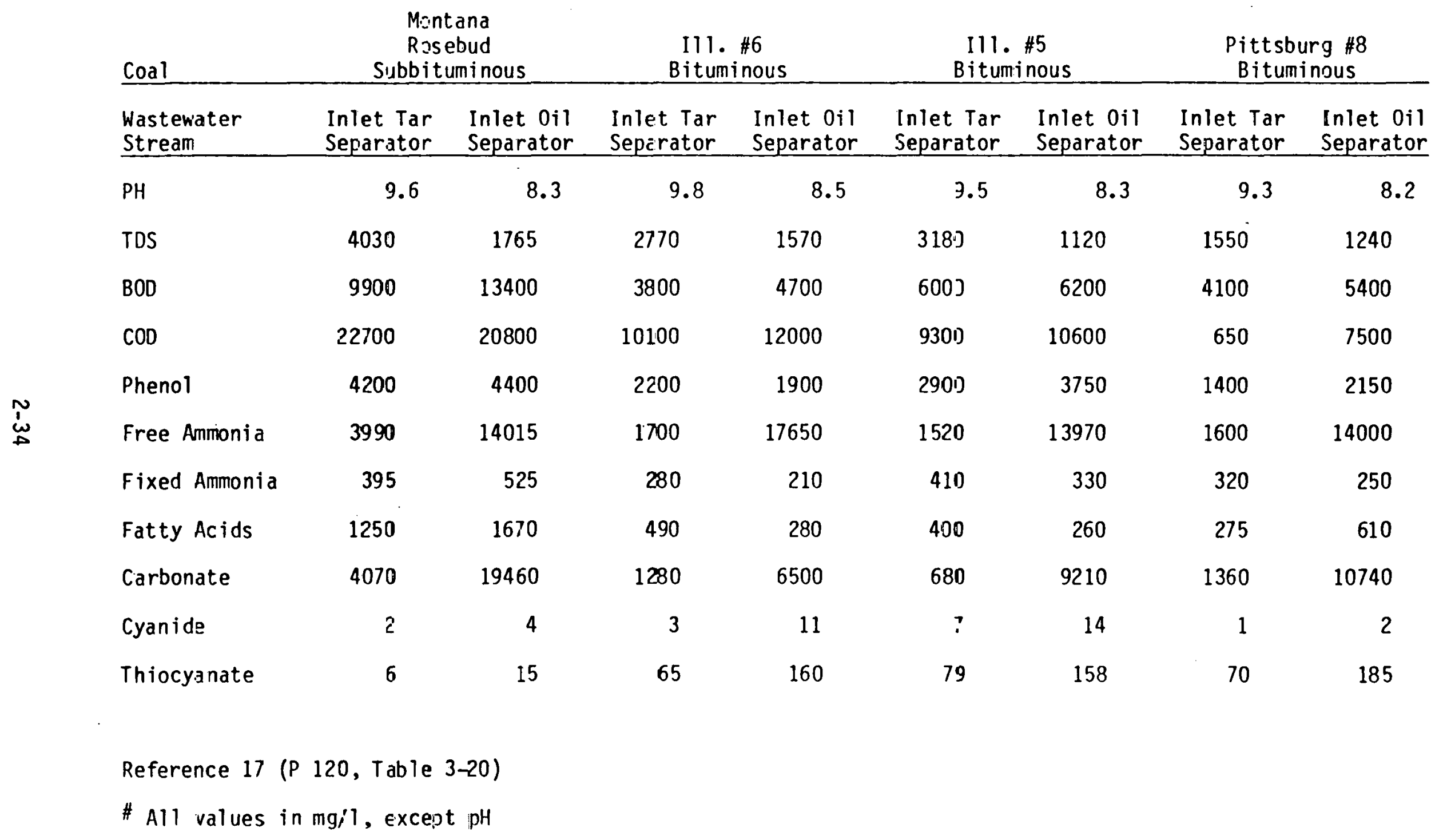


somewhat thermally inefficient and produced a great deal of condensate. The solution to this problem was to operate the gasifier with much less steam, allowing the bed temperatures to exceed the ash fusion temperature. Under these slagging conditions, the Lurgi process was able to efficiently gasify U.S. coals.

A slagging, fixed-bed gasifier was installed at the Grand Forks Energy Research Center (GFERC), Grand Forks, North Dakota, in 1958-1959. Operation of the plant was resumed in 1976. During 1977 and 1978, wastewaters from the gasification of various western U.S. coals were compared, and the process was modified to reduce the wastewater treatment required. The wastewater streams were analyzed for two runs of the gasifier $18,19,20$.

Samples from one run were analyzed for pH, TSS, COD, ammonia, phenol, sulfide, sulfate, total sulfur, cyanide, and thiocyanate. The samples were stored and analyzed according to procedures developed specifically for the wastewaters being studied. Difficulties were experienced because of a high concentration of suspended solids and oils in the sample. In addition, interferences were discovered during some analyses that pointed to interactions between the oils and solids. Because of large inconsistencies in values obtained and the inadequacies of some of the testing procedures, the data were not used. What these tests did reveal were the modifications necessary to the analys is procedures for wastewaters from slagging gasifiers.

A composite wastewater sample was collected in July of 1977 (Table 2.15). Equilibrium for the spray wash system for the gas quench was achieved towards the end of the steady state run. It can be seen that the pollutant levels from this-slagging gasifier are not significantly less than for the dry ash Lurgi process. The reasons for this unexpected result are not apparent.

\subsubsection{Hygas}

Hygas process development by the Institute of Gas Technology (IGT) began in 1946. The pilot plant was designed and built to convert 4 tons of coal per 
Table 2.15 End of Run Composition of Quench Water from GFERC Run RA-21*

Total Phenol

$\mathrm{NH}_{3}$

COD

TSS

$\mathrm{pH}$

TDS

Alk. as $\mathrm{CaCO}_{3}$

Cyanide

Thiocyanate

Sulfide

Total Sulfur
4378

9110

25410

440

8.1

10650

17130

94

296

358

421

Reference 20 (P 95, Tăble 18)

- All values in mg/l, except $\mathrm{pH}$ 
hour to 1.5 million cubic feet of gas per day. During 1973, pipeline quality gas was first produced in sustained steady-state conditions. At various times in the continued development and refinement of process operating conditions, steady-state conditions have been achieved. The longest continuous, steadystate Hygas test ( 7 days), using Illinois \#6 coal, was completed in 1979.

The Hygas pilot plant has some scalable wastewater streams, the two most important being ash slurry and product gas quench condensate. A significant difference difference between pilot plant operation and proposed commercial operation is in the treatment of pretreater off-gases. In pilot plant operation, gases evolved from the pretreater are quenched, and the condensate is combined with the product gas quench condensate. The low-temperature pretreater liberates high levels of phenols, which results in lower levels in the product gas condensate. In the proposed commercial operation, the pretreater off-gases will not be quenched but, instead, will be used as a fuel in the plant boilers. Pilot plant data in which the pretreater was used are not representative of commercial operation. The use of a pretreater results in reduced phenols in the raw gas quench water.

Compositions of wastewaters from the Hygas raw gas cyclone (operated dry in commercial operation) and the downstream raw gas quench are presented in Table 2.16. It should be noted that the values in this table are without pretreater operation. A review of these data shows that even though some phenol, ammonia, and other volatiles are removed in the pilot plant cyclone, most of these volatiles are removed in the quench section. Most suspended solids are removed in the cyclone. Wastewater contaminants from the Hygas process are less than from either the Synthane or the Lurgi processes.

The effect of pretreater operation is shown in Table 2.17. As shown, phenol levels and corresponding TOC levels are substantially reduced by pretreatment of the coal feed. Higher levels of suspended solids are a result of the coal type and not process variation. It is interesting to note that ammonia and cyanide levels were unaffected by pretreatment. Increased sulfur concentrations are a result of using high-sulfur coals. 
Table 2.16 Composition of Hygas Wastewaters During Tests Without Coal Pretreatment*

\begin{tabular}{|c|c|c|c|c|c|c|}
\hline \multirow[b]{2}{*}{ Component } & \multicolumn{2}{|c|}{$\begin{array}{l}\text { Test } 37 \\
\text { Lignite }\end{array}$} & \multicolumn{2}{|c|}{$\begin{array}{c}\text { Test } 52 \\
\text { Sub-Bituminous }\end{array}$} & \multicolumn{2}{|c|}{$\begin{array}{c}\text { Test } 58 \\
\text { Sub-Bituminous }\end{array}$} \\
\hline & $\begin{array}{l}\text { Raw Gas } \\
\text { Quench } \\
\text { Condensate }\end{array}$ & $\begin{array}{l}\text { Cyclone } \\
\text { Slurry } \\
\text { Water } \\
\end{array}$ & $\begin{array}{l}\text { Raw Gas } \\
\text { Quench } \\
\text { Condensate }\end{array}$ & $\begin{array}{l}\text { Cyclone } \\
\text { Slurry } \\
\text { Water }\end{array}$ & $\begin{array}{l}\text { Raw Gas } \\
\text { Quench } \\
\text { Condensate }\end{array}$ & $\begin{array}{l}\text { Cyclone } \\
\text { Slurry } \\
\text { Water } \\
\end{array}$ \\
\hline Phenol & 2055 & ND & 3772 & 1969 & 4390 & 2455 \\
\hline TOC & 4294 & ND & 7240 & 271.4 & 3324 & 1518 \\
\hline TDS & 1782 & ND & 1293 & 913 & 2089 & 669 \\
\hline TSS & 36 & ND & 67 & 2642 & 1011 & 26,000 \\
\hline $\mathrm{pH}$ & 7.2 & ND & 7.3 & 7.5 & 7.4 & 7.1 \\
\hline Ammonia & 3045 & ND & 4000 & 518 & 6048 & 257 \\
\hline Cyanide & Negligible & ND & 0.0006 & 0.003 & 0.01 & 0.01 \\
\hline Thiocyanate & 510 & ND & 385 & 211 & 214 & 198 \\
\hline Sulfate & 126 & ND & 104 & 39 & 195 & 34 \\
\hline $\begin{array}{l}N D=\text { Not } D \\
\text { * All values } \\
\text { Reference } 21\end{array}$ & $\begin{array}{l}\text { ermined } \\
\text { n mg/l except } \\
P 5, \text { Table 1) }\end{array}$ & & - & & & \\
\hline
\end{tabular}


Table 2.17 Composition of Hygas Wastewaters During Tests with Pretreater Operation*

\begin{tabular}{|c|c|c|c|c|}
\hline \multirow[b]{2}{*}{ Component } & \multicolumn{2}{|c|}{ Test No. 46 Bituminous } & \multicolumn{2}{|c|}{ Test No. 54 Bituminous } \\
\hline & $\begin{array}{l}\text { Product Gas } \\
\text { Quench } \\
\text { Condensate }\end{array}$ & $\begin{array}{l}\text { Cyclone } \\
\text { slurry } \\
\text { Water } \\
\end{array}$ & $\begin{array}{l}\text { Product Gas } \\
\text { Quench } \\
\text { Condensate }\end{array}$ & $\begin{array}{l}\text { Cyclone } \\
\text { Slurry } \\
\text { Water }\end{array}$ \\
\hline Phenol & 244 & 552 & 1227 & 394 \\
\hline TOC & 321 & 721 & 1008 & 509 \\
\hline TDS & 720 & 875 & 1090 & 432 \\
\hline TSS & 27,500 & 17,500 & 36 & 15,700 \\
\hline $\mathrm{pH}$ & 7.4 & 8.1 & 7.8 & 8.0 \\
\hline Ammonia & 7413 & 1168 & 6552 & 439 \\
\hline Cyanide & 0.02 & 0.04 & Negligible & Negligible \\
\hline Thiocyanate & 27 & 64 & 99 & 31 \\
\hline Sulfate & 333 & 473 & 1084 & 76 \\
\hline
\end{tabular}

* All values in $\mathrm{mg} / \mathrm{l}$, except $\mathrm{pH}$

Reference 21 ( $P 6$, Table 2) 


\subsection{4 $\mathrm{CO}_{2}$-Acceptor}

Wastewaters from the $\mathrm{CO}_{2}$-Acceptor pilot plant have been extensively sampled. The only scalable pilot plant wastewater stream is the raw gas quench condensate. Most sampling was done during Runs 39 and 45 . A summary of gasifier quench condensate characteristics is shown in Table 2.18. Contaminant concentrations are much lower than for the gasification processes previously discussed. Differences between runs can be partially attributed to the different coals gasified. Run 39 was fed Glenharold Lignite and Run 45 used Wyodak Subbituminous.

\subsubsection{Bi-Gas}

The Bi-Gas process has been under development at Bituminous Coal Research, Inc., since December, 1963. The bench-scale unit processed 5 pounds of coal per hour and generated design parameters used to scale up to a 120 ton/day pilot plant. The pilot plant in Holmer City, Pennsylvania, was completed in 1976. The most successful run of the pilot plant was completed in November, 1977, when a 24hour, steady-state condition was achieved.

The Bi-Gas pilot plant is fairly new, and as a result, numerous mechanical and structural failures have prevented long steady-state operations. Although most pilot plant studies have been process related, some wastewater characterization has been done. The Bi-Gas pilot plant unique in that all of the wastewater streams are scalable to a commercial-size facility.

Wastewater characteristics for the three most contaminated streams are shown in Table 2.19. The data presented are for information only, because steady-state conditions were not achieved. The recycle gas quench water originates from the coal drying area. The other two wastewater streams are those normally associated with coal gasification operations.

\section{4 .6 U-Gas}

Information on U-Gas process wastewaters, being generated by IGT, is not available outside of the MLGWD Industrial Fuel Gas Demonstration Project. 
Table 2.18 Characteristics of $\mathrm{CO}_{2}$-Acceptor Gasifier Quench Condensate*

\begin{tabular}{lrrr} 
Component & Run 39 & Run 45 & Average \\
\cline { 1 - 2 } TDS & 1520 & 930 & 1225 \\
TSS & 1780 & 4090 & 2935 \\
pH & 8.7 & 8.3 & 8.5 \\
COD & 87 & 43 & 65 \\
TOC & 2.5 & 3.2 & 2.9 \\
Ammonia & 2420 & 1210 & 1815 \\
Phenol & 0.011 & 0.4 & 0.2 \\
Alkalinity & 6270 & 4900 & 5585 \\
Cyanide & 7.8 & 11.1 & 9.5 \\
Thiocyanate & 5.6 & 2.6 & 4.1 \\
Chloride & 37 & 7.4 & 22
\end{tabular}

* All values in mg/l, except $p H$

Reference 22 ( $P$ 215, Table 6.1) 
Table 2.19 Characteristics of Wastewaters from Bi-Gas Pilot Plant Operation*

\begin{tabular}{|c|c|c|c|}
\hline Component & $\begin{array}{l}\text { Recycle Gas } \\
\text { Quench Water }\end{array}$ & $\begin{array}{l}\text { High Pressure Gas } \\
\text { Wash Water } \\
\end{array}$ & $\begin{array}{l}\text { Slag Quench } \\
\text { Water } \\
\end{array}$ \\
\hline TSS & 58,425 & 10,456 & 2440 \\
\hline TDS & 13,145 & 1594 & 834 \\
\hline COD & 116,700 & 16,400 & $\mathrm{NO}$ \\
\hline$B O D$ & 355 & 214 & ND \\
\hline Phenol & 0.37 & 22 & ND \\
\hline Ammonia & 4.7 & 305 & 8 \\
\hline Cyanide & 0.09 & 0.57 & 0.33 \\
\hline Thiocyanate & 0.5 & 0.92 & 0.5 \\
\hline Sulfide & ND & 9 & 15 \\
\hline Alkalinity & 6300 & 1821 & 350 \\
\hline$\mu H$ & 7.0 & 8.4 & 7.6 \\
\hline \multicolumn{4}{|c|}{$\begin{array}{l}N D=\text { Not Determined } \\
\star A 11 \text { values in } \mathrm{mg} / 1 \text {, except } \mathrm{pH}\end{array}$} \\
\hline
\end{tabular}




\subsubsection{Cogas}

The Cogas process consists of two steps. The first step, the pyrolys is of coal to produce gas, oils, and char, is referred to as Char 0 il Energy Development (COED). The second step of the process is the gasification of the char to produce a hot gas, which, in addition to being a raw product gas, supplies heat to the COED pyrolysis.

The main wastewater stream from the COED section is the raw gas quench condensate. This wastewater is characterized in Table 2.20. Data from the char gasifier raw gas quench are not available. The condensate associated with the pyrolysis section is scalable. Wastewater treatment for a commercial facility will differ from that of the pilot plant, however. In pilot plant operation, this wastewater is evaporated in the last pyrolysis stage, but it would be sent to a wastewater treatment system in a commercial-scale plant.

\subsubsection{Wink ler}

Although this gasification process has been in operation for over 50 years, information on wastewaters from gasifying U.S. coals is not available.

\subsubsection{Koppers-Totzek}

The Koppers-Totzek process is operating at commercial scale worldwide at over 13 locations. However, wastewater information from the gasification of U.S. coals is not available.

\subsubsection{Wellman Galusha}

The Wel Iman Galusha process has been operated at commercial scale for over 35 years. Over 150 gasifiers have been installed in various industrial applications. There are more than seven Wellman-Galusha gasifiers operating in the United States at large industrial plants. A pressurized version of this gasifier was built for the DOE Morgantown Energy Research Center (METC). Analyses of decanter water produced by the METC gasifier is shown in Table 2.21. 
Table 2.20 Characteristics of Cogas (COED Section) Raw Gas Quench Condensate*

\begin{tabular}{|c|c|c|c|c|c|}
\hline Component & $\begin{array}{l}\text { Illinois. } \\
\text { Bituminous }\end{array}$ & $\begin{array}{c}\text { N. Dakota } \\
\text { Lignite }\end{array}$ & $\begin{array}{c}\text { Utah } \\
\text { Bituminous } \\
\end{array}$ & $\begin{array}{l}\text { W. Kentucky } \\
\text { Bituminous }\end{array}$ & $\begin{array}{l}\text { Pittsburgh } \\
\text { Bituminous } \\
\end{array}$ \\
\hline TDS & 0.77 & ND & ND & ND & ND \\
\hline TSS & 1.58 & 0.29 & 0.39 & 0.53 & 1.08 \\
\hline Phenol & 0.41 & 1.04 & 0.54 & 0.17 & 0.2 \\
\hline Dil & Nח & 0.0 & 0.48 & 0.21 & 0.18 \\
\hline $\mathrm{pH}$ & 8.8 & 8.9 & 8.9 & 8.7 & 7.1 \\
\hline
\end{tabular}

ND $=$ Not Determined

* All values in weight percent, except $\mathrm{pH}$

Reference 24 (PA-6D, Table A-22) 
Table 2.21 Characteristics of Decanter Water Samples from METC/DOE Gasifier *

\begin{tabular}{|c|c|c|c|c|}
\hline Component & Run 85 & Run 86 & Run 88 & Run 90 \\
\hline TDS & ND & 3,876 & 3,289 & 5,140 \\
\hline TSS & ND & 21 & 38 & 36 \\
\hline Phenol & 1,230 & 2,955 & 2,460 & 300 \\
\hline Ammonia (Free) & 3,242 & 7,344 & 3,838 & 6,426 \\
\hline $\begin{array}{l}N \text { (Total) } \\
\text { COD }\end{array}$ & $\begin{array}{r}3,467 \\
87,251\end{array}$ & $\begin{array}{r}7,742 \\
\text { ND }\end{array}$ & $\begin{array}{r}\text { ND } \\
16,856\end{array}$ & $\begin{array}{r}\text { ND } \\
74,000\end{array}$ \\
\hline $\mathrm{pH}$ & 8.7 & 8.8 & 8.7 & 8.5 \\
\hline \multicolumn{5}{|c|}{$\begin{array}{l}N D=\text { No Data Available } \\
\star \text { All values in mg/l, except } \mathrm{pH} \\
\text { Reference } 25 \text { (P8, Table } 4 \text { ) }\end{array}$} \\
\hline
\end{tabular}


Of interest are the low suspended solids levels and the high COD values. METC attributes the high COD value partially to reduced inorganics, such as sulfides. Further testing by METC will further characterize the wastewaters from this process.

\subsubsection{Iexaco}

The Texaco coal gasifier is a pressurized, entrained-bed, downflow slagging gasifier. Two pilot units operating at 300 to $1,200 \mathrm{psi}$, respectively, have been gasifying 15 to 20 tons per day of an eastern U.S. coal (IIlinois \#6) and two western U.S. coals (Kaiparowits). Tables 2.22 and 2.23 presents the compositions of these test coals ${ }^{26}$.

Tables $2.24,2.25,2.26$, and 2.27 compare wastewater composition for the two test coals to the input process water. The slag wastewater is blowdown from slag quench settling, and the excess wastewater is a combined raw gas quench and excess gasifier slurry wastewater stream. 
Table 2.22 Texaco Coal Analyses

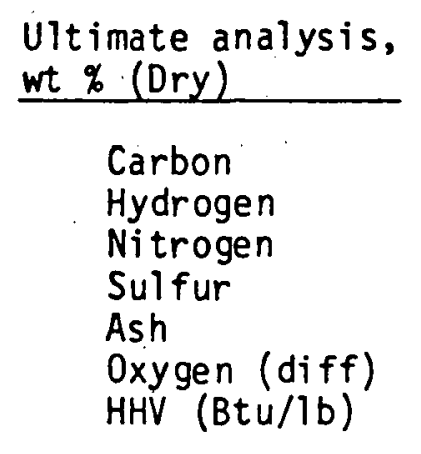

\begin{tabular}{|c|c|}
\hline $\begin{array}{c}\text { Eastern } \\
\text { coal } \\
\end{array}$ & $\begin{array}{c}\text { Western } \\
\text { coal }\end{array}$ \\
\hline $\begin{array}{r}65.56 \\
4.76 \\
1.27 \\
4.17 \\
13.15 \\
11.09 \\
11.736\end{array}$ & $\begin{array}{r}67.80 \\
4.72 \\
1.17 \\
0.35 \\
11.22 \\
14.74 \\
11.707\end{array}$ \\
\hline
\end{tabular}

Table 2.23 Texaco Analyses Trace Components

Element, ppm

Antimony

Arsenic

Barium

Beryllium

Boron

Chlorine

Cadmium

Chromium

Cobalt

Copper

Fluorine

Lead

Manganese

Mercury

Molyvdenum

Nickel

Selenium

Silver

Thal lium

Vanadium

Zinc
Eastern
coal

1.2

8.0

64

0.6

NR

602

1.4

35

5

19

96

23

95

0.08

8

55

2

0.2

0.25

25

147
Western

coal

$<0.5$

$<0.9$

320

$<0.2$

15

24

0.2

34

0.9

8

65

4.0

34

0.1

0.3

3.7

1.7

0.3

0.3

14

7.9 
Table 2.24 Texaco Water Quality Data Eastern Coal

\section{Component}

$\mathrm{pH}$

TDS, ppm

Conductivity

COD, ppm

TOC, ppm

Ammonia, ppm

Anions, ppm

Bromide

Chloride

Fluoride

Cyanide

Formate

Nitrate

Sulfide

Sulfate

Thiocyanate

Thiosulfate
Process

water

NR

0.0

NR

NR

<1

NR

Slag

water

Excess

water

8.0

355

1650

221

28

380

$<1$

29

$<1$

NR

<1

$<1$

0.3

25

NR

NR

$<1$

146

31

$<1$

94

3

6

38

2

5

7100

405

215

1270

Trace organics, ppb

Benzene

$<0.5$

3.0

Tolucnc

Anthracene

$<0.5$

2.0

1.0

0.

Fluoranthene

2.0

0.5

Naphthalene

Pyrene

- 2.0

Phenanthrene

0.6

0.7

Phenols 


\section{Component}

$\mathrm{pH}$

TDS, ppm

Conductivity

COD, ppm

TOC, ppm

Ammonia, ppm

Anions, ppm

Bromide

Chloride

Fluoride

Cyanide

Formate

Nitrate

Sulfide

Sulfate

Thiocyanate

Trace organics, ppb

Phenols

Unidentified
Table 2.25 Texaco Water Quality Western Coal

Process Slag Excess

water in water out water out

$\begin{array}{crr}5.3 & 8.9 & 8.8 \\ <5 & 28 & 420 \\ <10 & 410 & 10,800 \\ <5 & 48 & 760 \\ 0.4 & 38 & 360 \\ <1 & 130 & 2700\end{array}$

$\begin{array}{ccc}<0.05 & <0.05 & <0.05 \\ <0.1 & 42 & 7.5 \\ <0.01 & <0.1 & 28 \\ <0.2 & 0.4 & 11 \\ <0.1 & 56 & 1200 \\ <0.5 & <0.5 & 2.0 \\ <0.5 & <0.5 & 61 \\ 1.3 & 5 & 47 \\ <4 & <4 & 29\end{array}$

NR

1.2

1.2

NR

7.0

2.8 
Table 2.26 Texaco Trace Elements in Water Streams Eastern Coal

Element, ppm

Ant imony

Arsenic

Barium

Beryllium

Boroll

Cadmium

Chromium

Cobalt

Copper

Fluorine

Lead

Manganese

Mercury

Molybdenum

Nickel

Selenium

Silver

Thal lium

Vanadium

Zine.

\begin{tabular}{cccc}
$\begin{array}{c}\text { Process } \\
\text { water }\end{array}$ & & $\begin{array}{c}\text { Slag } \\
\text { water }\end{array}$ & $\begin{array}{c}\text { Excess } \\
\text { water }\end{array}$ \\
\cline { 1 - 1 }$<0.001$ & & .016 & $<.001$ \\
0.002 & & .07 & .022 \\
0.003 & & .10 & .54 \\
0.0004 & .005 & .018 \\
.. & &. & - \\
0.010 & & .003 & .003 \\
0.002 & .003 & .006 \\
0.005 & & .10 & .021 \\
0.01 & & 0.017 & .010 \\
$<1$ & & & 175 \\
0.005 & & .045 & .054 \\
0.13 & & .08 & .104 \\
$<0.0001$ & $<.0001$ & $<.0001$ \\
$<0.02$ & .03 & $<.02$ \\
0.03 & .07 & .03 \\
0.005 & 0.033 & 0.010 \\
0.0006 & 0.002 & 0.002 \\
0.002 & .006 & .01 \\
$<0.04$ & $<.04$ & $<.04$ \\
0.195 & .046 & .03
\end{tabular}


Table 2.27 Texaco Trace Elements in Water Streams Western Coal

\section{Element, ppm}

Antimony

Arsenic

Barium

Beryllium

Boron

Cadmium

Chromium

Cobalt

Copper

Fluorine

Lead

Manganese

Mercury

Molybdenum

Nickel

Selenium

Silver

Thall ium

Vanadium

Zinc

\begin{tabular}{|c|c|c|}
\hline $\begin{array}{l}\text { Process } \\
\text { water }\end{array}$ & $\begin{array}{l}\text { Slag } \\
\text { water } \\
\end{array}$ & $\begin{array}{r}\text { Excess } \\
\text { water } \\
\end{array}$ \\
\hline$<0.001$ & $<0.001$ & $<0.001$ \\
\hline$<0.001$ & 0.015 & 0.016 \\
\hline 0.004 & 0.05 & 0.90 \\
\hline$<0.001$ & $<0.001$ & 0.002 \\
\hline 0.2 & 0.3 & 1.4 \\
\hline$<0.006$ & $<0.001$ & $<0.001$ \\
\hline$<0.001$ & $<0.001$ & $<0.001$ \\
\hline$<0.001$ & $<0.001$ & $<0.001$ \\
\hline 0.031 & 0.008 & 0.005 \\
\hline$<0.1$ & $<0.01$ & 29 \\
\hline$<0.005$ & 0.011 & $<0.005$ \\
\hline 0.002 & 0.003 & 0.024 \\
\hline 0.002 & 0.002 & 0.002 \\
\hline$<0.001$ & 0.003 & 0.015 \\
\hline$<0.01$ & $<0.01$ & $<0.01$ \\
\hline$<0.001$ & 0.025 & 0.460 \\
\hline$<0.002$ & $<0.002$ & $<0.002$ \\
\hline$<0.002$ & $<0.002$ & 0.003 \\
\hline$<0.01$ & $<0.01$ & $<0.03$ \\
\hline$<0.01$ & $<0.01$ & $<0.01$ \\
\hline
\end{tabular}




\section{SECTION 3 - WASTEWATER TREATABILITY STUDIES}

\subsection{INTRODUCTION}

All coal gasification processes will use large quantities of water and produce wastewaters that require treatment prior to discharge or reuse. Current water quality regulations may impose strict constraints on wastewaters discharged from coal gasification facilities. Ultimately, these facilities may face the constraint that no wastewaters are to be discharged from the plant boundaries.

Preliminary wastewater source identification and characterizations from pilot plant operations indicate a need for further treatability studies to identify potential treatment processes. A survey of processes indicated that a major wastewater source in all gasification processes is the raw gas quench condensate. Quench condensates from first-generation processes, such as dry ash Lurgi, are contaminated by high levels of organics, ammonia, and other materials. Second-generation processes, such as Synthane and $\mathrm{CO}_{2}$-Acceptor, generate less contaminated wastewaters. The quench condensates from most gasifiers are characterized by high concentrations of suspended solids, ammonia, organics (notably phenols), tars, and oils.

\subsection{INDUSTRY EXPERIENCE}

Wastewater treatment processes used by industries having wastewaters similar to those produced during coal gasification were investigated because the U.S. operating experience in these industries greatly exceeds that for coal gasification. It was found that coking wastewaters have characteristics similar to those produced by coal gasification. Some wastewaters generated during petroleum processing are also simflar to those generated from coal gasification. The information obtained from processes used to treat these related wastewaters can then be applied to the analyses of treatment systems for coal gasification wastewaters in the U.S. A review of wastewater treatability information for coking and refinery wastewaters and of treatability studies on gasification wastewaters follows. 


\subsubsection{Coking Industry}

Given the many similarities between coking and coal gasification processes, including the individual process sources of wastewaters, it seems reasonable to assume that the wastewaters from coking and coal gasification will have similar characteristics. Coking wastewater treatment technology should be effective in treating coal gasification wastewaters.

Coke is produced by destructive carbonization of low-sulfur, bituminous coal in the absence of oxygen. Coal used in making coke is usually a blend of high volatile coal with 10 to $50 \%$ of low-volatile coal. The blend should not contain over $1.5 \%$ sulfur and $9 \%$ ash. Coking processes are designed to recover byproduct gases and chemicals. Major unit operations in a coke plant are coal handling and preparation; coking; quenching; primary cooling; tar separation; tar extraction; ammonia removal; final cooling; light oil scrubbing; and sulfur removal. Modern coking plants have refining facilities for the recovery of benzene, toluene, and xylene from the light oils. Cleaned coke gas is often used as a low-Btu fuel source.

Coking takes place at atmospheric pressure and temperatures between $2000^{\circ} \mathrm{F}$ and $2100^{\circ} \mathrm{F}$ in 16 to 27 hours. Coking a ton of coal will produce approximately 78 pounds of tar, 5 pounds of anhydrous ammonia, 20 pounds of light oil, and 309 pounds $(10,350 \mathrm{scf})$ of gas. It was found (Table 3.1) that some similarities exist among the effluent gases from coal gasification and coking processes. However, wide variations do exist. The higher $\mathrm{CO}_{2} / \mathrm{H}_{2} \mathrm{~S}$ ratios for gasification reactions, for instance, will make sulfur removal and recovery more difficult than for gases in the coking industry.

Compositions of raw gas quench wastewaters from gasification and coking are compared in Table 3.2. Ranges and types of contaminants are reasonably close. The concentrations of contaminants in coking wastewaters are usually high enough to make recovery and sale economical. The coking industry uses steam stripping for ammonia removal. If feasible, the stripped ammonia is recovered by using the Phosam $W$, or similar process. Stripped phenols are most of ten recovered using a solvent extraction process. 
Table 3.1 Compositions of Effluent Gases From Gasifiers and Coke Ovens ${ }^{1}$

\begin{tabular}{|c|c|c|c|}
\hline Component & Lurgi ${ }^{2}$ & ${\underline{K-T^{3}}}^{3}$ & Coke $^{4}$ \\
\hline $\mathrm{H}_{2}$ & 22.63 & 26.37 & 38.22 \\
\hline CO & 11.65 & 51.79 & 6.18 \\
\hline $\mathrm{CO}_{2}$ & 16.16 & 8.82 & 1.33 \\
\hline $\mathrm{O}_{2}$. & None & None & 1.26 \\
\hline $\mathrm{N}_{2}$ & 0.18 & 0.69 & 0.45 \\
\hline $\mathrm{NH}_{3}$ & 0.55 & 0.08 & 0.70 \\
\hline $\mathrm{HCN}$ & 0.16 & 0.02 & 0.16 \\
\hline $\mathrm{H}_{2} \mathrm{~S}$ & 0.20 & 0.41 & 0.51 \\
\hline $\cos$ & 0.007 & 0.04 & 0.02 \\
\hline $\mathrm{CS}_{2}$ & None & None & 0.01 \\
\hline Light $0 i 1$ & 0.14 & None & 0.79 \\
\hline Tar $0 i 1$ & 0.11 & None & None \\
\hline Tar & 0.10 & None & 0.78 \\
\hline Phenol & 0.05 & None & 0.04 \\
\hline $\mathrm{H}_{2} \mathrm{O}$ & 41.07 & 11.78 & 21.05 \\
\hline Temperature $\left({ }^{\circ} \mathrm{F}\right)$ & 370 & 2730 & 1000 \\
\hline Pressure (psia) & 450 & 15.3 & 14.3 \\
\hline $\mathrm{CO}_{2} / \mathrm{H}_{2} \mathrm{~S}$ & 79.6 & 21.5 & 2.6 \\
\hline \multicolumn{4}{|c|}{1 All values in volume-percent } \\
\hline \multicolumn{4}{|l|}{2 sub-bituminous } \\
\hline \multicolumn{4}{|c|}{3 Texas Lignite $(1.5 \% \mathrm{~S})$} \\
\hline 4 Bituminous (1\% & & & \\
\hline
\end{tabular}


Table 3.2 Composition of Quench Wastewater From Gasification and Coking Processes

\begin{tabular}{|c|c|c|c|c|}
\hline Parameter & $\begin{array}{c}\text { Coke Plant } \\
\mathrm{mg} / \mathrm{l}\end{array}$ & $\begin{array}{c}\text { Synthane } \\
\mathrm{mg} / 1 \\
\end{array}$ & $\begin{array}{r}\text { Lurgi } \\
\mathrm{mg} / 1 \\
\end{array}$ & $\begin{array}{l}\mathrm{K}-\mathrm{T} \\
\mathrm{mg} / \mathrm{l}\end{array}$ \\
\hline $\mathrm{pH}$ & 8.4 & 8.6 & 8.9 & 8.9 \\
\hline Suspended Solids & 4000 & 600 & 5000 & 50 \\
\hline Phenol & 1000 & 2600 & 3500 & None \\
\hline$C O D$ & $10 n \cap n$ & 15000 & 12500 & 70 \\
\hline Thincyạ nạte & 1000 & 152 & Nülle & None \\
\hline Cyanide & 50 & NR & NR & 0.7 \\
\hline Ammonia & 5000 & 8100 & 11200 & 25 \\
\hline Chloride & 6000 & 500 & NR & 600 \\
\hline Carbonate & NR & 6000 & 10000 & 1200 \\
\hline Sulfide & 1250 & 1400 & NR & NR \\
\hline
\end{tabular}

$N R=$ Not Reported

Reference 27 (P8, Table 1-3) 
Other removal processes that can be used for. ammonia and phenols are biological oxidation and carbon adsorption. Dilution of the incoming stream may be required to avoid feeding excessively high concentrations of ammonia and phenols to these removal processes.

Biological treatment is often found to be the most cost-effective method to treat wastewaters containing organic pollutants. This type of treatment has been used for coking wastewaters pumped to municipal sewage treatment plants after dilution of the phenol concentration to $30-40 \mathrm{mg} / 1$.

Extensive testing was done to optimize the biological treatment of these wastewaters in the 1960 's. In 1969, pilot plant work by Kostenbader and Flecksteiner 28 at the Bethlehem Steel Corporation found that phenol could be oxidized at loadings of $0.86 \mathrm{mg}$ phenol/mg sludge-day with detention times as short as 1.6 hours. This necessitated mixed liquor suspended solids (MLSS) concentrations of $5600 \mathrm{mg} / 1$, which resulted in operational problems. The high loading, equivalent to $2 \mathrm{mg} \mathrm{BOD/mg} \mathrm{sludge-day,} \mathrm{resulted} \mathrm{in} \mathrm{excessive} \mathrm{foaming} \mathrm{and} \mathrm{sludge}$ bulking. After much experimentation, it was found that at loadings of $0.7 \mathrm{mg}$ phenol/mg sludge-day, phenol could be successfully removed. Recommendations from this study were:

1) Tar should be removed before biological treatment;

2) Ammonia concentrations in the aeration tank should be limited to 2000 $\mathrm{mg} / \mathrm{l}$;

3) The aeration tank temperature should be maintained between 80 and $95^{\circ} \mathrm{F}$;

4) Phosphorus should be added as a nutrient in a ratio of 1 part phosphorus to 70 parts phenol; and

5) The $\mathrm{pH}$ in the biological reactor should be maintained between 6 and 8 .

A summary of operating data from this study is shown in Table 3.3. It can be seen that influent phenol concentrations of about $3700 \mathrm{mg} / \mathrm{l}$ were reduced to less than $1.0 \mathrm{mg} / 1$, a removal rate of $99.99 \%$. There was no removal of ammonia by nitrification. Thiocyanate removal was very erratic, ranging from $10 \%$ to 99\%. No evidence was found in Kostenbader's work that could explain this behavfor. Cyanide removal paralleled thiocyanate reilioval. 
Activated carbon has been used at the Cleveland District Coke plant 27 , a facility of Republic Steel Corporation. Ammonia liquor blowdown, containing $1600 \mathrm{mg} / \mathrm{l}$ of phenol, is first pretreated with a solvent extracting process reduce the phenol content to about $30 \mathrm{mg} / 1$. Other low-strength wastewaters containing less than $40 \mathrm{mg} / 1$ of phenol are also treated with activated carbon after $0 i 1$ and suspended solids removal. Minimal removals for ammonia and cyanide were obtained from activated carbon. Contact times over 60 minutes were required for optimum removals.

The application of activated carbon to treatment of coke plant wastewaters has also been reported by $H$. Juntgen 29 . A sidestream was treated in an upflow pilot plant adsorption column. Average removals are shown in Table 3.4. During the pilot plant operation, the carbon loss in the regeneration cycle was only $3 \%$. The wastewater was pretreated by filtering and oil and tar removal. Pilot plant data were used to design a $100 \mathrm{gpm}$ demonstration plant built near a medium-size coking plant in Germany.

Act ivated sludge has been used 27 at the Lone Star Steel Company to treat ammonia still waste liquor. The plant was designed to reduce influent phenol concentrations of 100 to $800 \mathrm{mg} / 1$ to less than $1 \mathrm{mg} / 1$ at flow volumes of $500,000 \mathrm{gpd}$. The optimum operating conditions were a detention time of 24 hours and a phenol loading of 0.2 to $0.25 \mathrm{lb} /$ day/1b MLSS at a MLSS concentration of $2500-3500 \mathrm{mg} / 1$. During full-scale operation, phenol concentrations were reduced from 250-475 $\mathrm{mg} / 1$ to 0.1 to $0.3 \mathrm{mg} / \mathrm{l}$, with partial removal of cyanides.

Barker and Thomson 30 investigated the efficiency of using a carbonaceous removal unit, a nitrification unit, and a denitrification unit in series to remove both organic and ammonia compounds. In the carbon removal unit, $C O D$ is reduced from $3000 \mathrm{mg} / 1$ to $900 \mathrm{mg} / 1$ and phenols are reduced from $600 \mathrm{mg} / 1$ to below $1 \mathrm{mg} / 1$. The detention time was 24 hours and the temperature was maintained between 75 to $90^{\circ} \mathrm{F}$. Treatment efficiency was found to increase at higher temperatures. Thiocyanate was partially removed and $60 \%$ of the cyanide was removed in the carbon unit. The nitrification unit, operating with the influent diluted to $12 \%$ of its original concentration, oxidized the ammonia. The denitrification unit removed over $95 \%$ of the oxidized nitrogen. 
Table 3.3 Operating Data From Pilot Plant Act ivated Sludge Units Processing Raw Coke Plant Weak Ammonia Liquor (WAL)

\begin{tabular}{|c|c|c|c|c|c|c|c|}
\hline \multirow[t]{2}{*}{ Parameter } & \multicolumn{7}{|c|}{ Operating Periods } \\
\hline & 1 & 2 & 3 & 4 & 5 & 6 & 7 \\
\hline WAL Flow (GPM) & 0.74 & 0.85 & 1.21 & 0.95 & 0.82 & 0.40 & 0.44 \\
\hline Dilution Flow (GPM) & 2.9 & 3.9 & 5.5 & 4.5 & 3.5 & 2.0 & 2.0 \\
\hline Dilution Ratio & $1: 3.9$ & $1: 4.6$ & $1: 4.5$ & $1: 4.7$ & $1: 4.3$ & $1: 5$ & $1: 4.5$ \\
\hline $\begin{array}{l}\text { Hydraulic Residence } \\
\text { Time (Hours) }\end{array}$ & 1.6 & 2.2 & 1.6 & 1.9 & 1.9 & 3.0 & 4.4 \\
\hline Temperature $\left({ }^{\circ} \mathrm{F}\right)$ & 90 & 92 & 92 & 90 & 87 & 80 & 80 \\
\hline $\mathrm{pH}$ & $7.5-7.6$ & $7.4-7.7$ & $7.3-7.5$ & $7.3-7.4$ & $7.3-7.4$ & $7.1-7-3$ & $6.9-7.3$ \\
\hline $\begin{array}{l}\text { Influent Phenol } \\
(\mathrm{mg} / \mathrm{l})\end{array}$ & 3700 & 3900 & 3500 & 3700 & 3400 & 3450 & 3350 \\
\hline Phenol Loading & 0.68 & $0.76-$ & $0.85-$ & 0.80 & 0.66 & $0.43-$ & $0.51-$ \\
\hline $\begin{array}{l}\text { mg Phenol/Day/mg } \\
\text { Sludge }\end{array}$ & 0.75 & 0.80 & 0.90 & 0.83 & 0.89 & 0.48 & 0.63 \\
\hline $\begin{array}{l}\text { Effluent Phenol } \\
(\mathrm{mg} / 1)\end{array}$ & $0.3-0.5$ & $0.4-0.5$ & $0.4-0.7$ & $0.5-0.8$ & $0.2-0.4$ & 0.2 & $0.2-0.3$ \\
\hline
\end{tabular}

Reference 28 (P 202, Table 1) 
Table 3.4 Coke Plant Wastewater Influent Concentrations and Act ivated Carbon Removal Efficiencies

Impurities

Phenol

Cyanide

Thiocyanate

Iron

Solids

T.OC

COD
Influent Concentration (mg/l) Removal Efficiencies $650-1400$ $99 \%$

5-35

$45-70 \%$

$30-80 \%$

$40-150$

$30 \%$

300-3000

$99 \%$

800-20กก

85-95\%

$2000-4000$

$80-99 \%$ 
The Alon Wood Steel plant 27 treats coking wastewaters by ammonia stripping, biological treatment, evaporation, and incineration. The raw wastewater contains $300-4000 \mathrm{mg} / 1$ of phenols, $3900-6000 \mathrm{mg} / \mathrm{l}$ of $\mathrm{NH}_{3}, 10-100 \mathrm{mg} / \mathrm{l}$ of cyanide, $50-500 \mathrm{mg} / 1$ of thiocyanate, $20-40 \mathrm{mg} / 1$ of tars and 0 il s, $30-120 \mathrm{mg} / 1$ suspended solids, and $4000-13000 \mathrm{mg} / 1$ of dissolved solids. The wastewater is pretreated in a downflow pressure filter to remove suspended solids, oil, and tar. The filtered effluent is stripped of ammonia and processed through an evaporator. The condensed vapors from evaporation are treated for phenol reduction by biological oxidation followed by ozonation or carbon adsorption polishing. The treated distillate is recycled back to the process. The evaporator bottoms are incinerated. It is not known what removal efficiencies are obtained at this plant.

Work performed by Adams 31 on coking wastewaters showed that phenol concentrations in treated wastewaters can be expected to be less than $0.1 \mathrm{mg} / 1$ only $40 \%$ of the time at loadings of 0.2-0.3 lb BOD per lb of mixed liquor volatile suspended solids (MLVSS) per day. Nitrification was observed, but was not significant at BOD loadings above 0.3. A two-stage activated sludge process was recommended to reduce ammonia-nitrogen levels to less than $10-15 \mathrm{mg} / 1$.

Pretreatment of wastewaters for phenol and ammonia removal is widespread in the coking industry. Further reduction in contaminants can be accomplished by biological oxidation if the ammonia concentration is below $1800 \mathrm{mg} / 1$ and the treatment system is well insulated from influent volume and composition variations. Activated carbon adsorption is also used, but extensive pretreatment is required. Carbon adsorption will remove only low concentrations of phenols and color. Another disadvantage of activated carbon treatment, besides the high cost, is its inability to remove ammonia.

\subsubsection{Petroleum Refinery Institute}

Petroleum refineries and coal gasifiers generate wastewaters that are similar in composition; these wastewaters require sour water stripping and oil/water separation. Refinery sour gas has higher $\mathrm{H}_{2} \mathrm{~S}$ concentrations and very $\mathrm{low}_{2} \mathrm{CO}_{2}$ concentrations compared to gasification raw gases. Refinery wastowaters contain 
high levels of sulfides and little or moderate quantities of ammonia, whereas gasification wastewaters have low levels of sulfides and moderate levels of ammonia. The processes used to treat these wastewaters are sufficiently similar for qualitative comparison.

Stripping is commonly used in refineries to remove $\mathrm{H}_{2} \mathrm{~S}$ and $\mathrm{NH}_{3}$ from sour waters. Conventional steam stripping can achieve greater than $99 \%$ removal of $\mathrm{H}_{2} \mathrm{~S}$ and up to $95 \%$ removal of $\mathrm{NH}_{3}$. Patented processes are used to simultaneously strip and recover sulfur and ammonia from wastewaters. These processes can reduce $\mathrm{H}_{2} \mathrm{~S}$ concentrations to $5 \mathrm{mg} / 1$ and ammonia concentrations to $50 \mathrm{mg} / 1$. Phenols are also removed from wastewaters in steam stripping operations.

The first treatment step for the removal of oil and suspended solids from oily wastewaters is gravity separation. The API-type separator is the most widely used for this purpose. Chemicals may be added to assist in the removal of solids in gravity separators.

$0 i 1$ and solids concentrations are reduced further by treatment in dissolved air flotation (DAF) units. DAF units may reduce oil by up to $80 \%$ and $\operatorname{COD}$ by $70 \%$. Addition of phosphate before treatment has been found to increase the COD removal to $90 \%$ and the oil removal to $98 \%$. These higher remnval levels are very beneficial because of the decrease in downstream contaminant loadings. The added phosphorus is also needed as a nutrient in downstream biological processes. DAF units can reduce oils to $10 \mathrm{mg} / \mathrm{l}$ if gravity separators are used unstream.

Many refineries reduce organics concentrations in wastewater still further by using biological oxidation. Refineries use either activated sludge units or aerated ponds and lagoons to achieve biological oxidation of the wastewaters. Ponds and lagoons are used when wastewaters have relatively low organics concentrations and when land is available near the refinery. If the organics levels are higher, or land is not available, the activated sludge process is used. 
Some refineries have installed activated carbon adsorption systems for reducing organics levels without bio-oxidation or for polishing wastewaters after biological oxidation. Operating parameters are lacking in the literature.

Ozone has also been used as a polishing step after bio-oxidation, primarily for reducing phenol concentrations. It is not clear if ozonation has advantages over other tertiary processes, but its high cost limits its use.

\subsubsection{Coal Gasification Industry}

Treatability studies have been performed on wastewaters from most coal gasification pilot plants under development in the U.S. These studies have focused on the reduction of organic contaminants in the raw gas quench condensates. The treatment process most often investigated has been activated sludge. Wastewaters have been obtained from pilot plants or made up synthetically from characterization data obtained from pilot plants. Single pollutants, such as phenol, have also been studied. Some process parameters for the biological treatment of coal gasification raw gas quench condensate have been obtained from these treatability studies.

It must be pointed out that these studies are at the bench scale, and much more information is required for the design of a wastewater treatment system suitable for demonstration or commercial coal gasification facilities. Coal gasification pilot plants have not generated wastewater streams under ideal testing conditions. Most pilot plants generate small amounts of process wastewaters during a relatively short run. This limits the scale of a continuous treated-as-produced experiment. This problem has been circumvented by accumulating larger amounts of wastewater in containers and treating the accumulated wastewater offsite. However, this procedure introduces significant errors into the treatability study results. The effects of process variations on the wastewater treatment process are eliminated. Even though some flow equalization will take place prior to biological treatment in larger-scale plants, the effects of variations in volume flow and composition of influent wastewaters on the wastewater treatment system should be determined. 
The validity of pilot plant test results is also compromised by the lack of steady state operation. Pilot plant gasification runs are on the order of days, or even hours. Wastewater data from these short steady-state runs, or from non-steady-state runs, may not be applicable to full-scale plants.

Most coal gasification processes are in the development stage. The composition of quench condensates and other wastewaters depends on the coal being gasified and the conditions under which gasification takes place. At this time, dependable wastewater treatability data are not available hecause the composition of wastewaters to be tested is uncertain. Nevertheless, data obtained in the previous limited tests, combined with experience in treating similar wastewaters, allow treatability predictions to be made with some degree of assurance.

0 il and Suspended Solids Removal

Johnson, et al.15 investigated the removal and recovery of tars, oils, and greases from Synthane wastewaters. These contaminants must be removed before other downstream wastewater treatment because they will coat and foul equipment surfaces and will inhibit biological treatment. Tars and oils appear both as insoluble and soluble fractions in Synthane wastewaters.

Soluble tar-like materials were precipitated from Synthane wastewater by depressing the $\mathrm{pH}$ to 2.0. The precipitate was sequentially extracted with freon and acetone. Tar removal from wastewaters by sedimentation was also investigated using pH depression, alum addition, and organic polyelectrolyte addition at various $\mathrm{pH}$ levels. The results are described below.

Synthane raw gas condensate typically contained about $22,000 \mathrm{mg} / 1$ of $\mathrm{tar}$, oils, and greases. Settling for 3-6 hours reduced this concentration by $95 \%$ to 1100 $\mathrm{mg} / 1$. The supernatant was treated by addition of alum after depressing the $\mathrm{pH}$ to about 2.0. Alum dosages in the range of $100-150 \mathrm{mg} / 1$ achieved the best and most consistent removal rates. Up to about $47 \%$ of the tar/oil remaining in the supernatant could be removed with alum. The remaining $3 \%$ of the original tar/ oil can be removed by biological and/or adsorption methods. 
The use of alum to remove only $2 \%$ of the original tar/oil is questionable from an economic standpoint. Even if alum addition is used to also reduce settling time, its use is debatable. This highly alkaline and well-buffered Synthane wastewater requires large quantities of acid to lower the $\mathrm{pH}$ for alum treatment. There are also various operational problems associated with $\mathrm{pH}$ depression, such as equipment failure caused by corrosion, foaming, and liberation of gases during acid addition. Studies with polyelectrolytes on similar wastewaters showed a lack of consistent removal rates.

P.C. Singer and others at the University of North Carolina-Chapel Hill $\mathrm{H}^{32}$ have investigated tar and oil removal from a synthetic wastewater. No additional solids were precipitated by depressing the $\mathrm{pH}$ below 5.3. TOC and COD removals were optimal between $\mathrm{pH}^{\prime} \mathrm{s}$ of 6.5 and 4.8 . These reductions in TOC and COD are due to the removal of settleable solids and tars. Tars could be effectively precipitated by acidification to $\mathrm{pH}$ levels between 4.5 and 5.0 , where $94 \%$ of acetone-soluble tar, $16 \%$ of COD, and $22 \%$ of TOC were removed. Alum was found to be an ineffective coagulant. Organic cationic polyelectrolytes were found to be effective coagulants, but at uneconomical doses.

Dissolved Gas Removal

Slack33 found that the use of $\mathrm{NaOH}$ as a $\mathrm{pH}$ conditioner for ammonia stripping resulted in high levels of dissolved solids (TDS) $(10,000-20,000 \mathrm{mg} / 1)$, which appeared to impair the settling of biomass in the downstream biological oxidation processes. Raising the $\mathrm{pH}$ with lime resulted in lower TDS levels and better settling in the biological reactor. It was concluded that lime would be the preferred method for raising the $\mathrm{pH}$ of wastewaters for ammonia stripping.

Pretreatment of Hygas wastewater to remove alkalinity and ammonia is necessary before biological oxidation. 34 A residual alkalinity of $1000 \mathrm{mg} / \mathrm{l}$ is needed to buffer $\mathrm{pH}$ fluctuations during bio-oxidation. Higher alkalinity resulted in a $\mathrm{pH}$ rise as $\mathrm{CO}_{2}$ was stripped by the bio-reactor aeration. Alkalinity was reduced to the necessary residual value by adding 18 to 20 milligrams of lime per liter of wastewater. 
Ammonia was removed by air stripping the wastewater at a $\mathrm{pH}$ of 10 . The wastewater effluent from the stripping unit contained between 100 and $150 \mathrm{mg} / 1$ of ammonia. Use of this method of pre-treatment removed about $92 \%$ of the alkalini.ty and $95 \%$ of the ammonia in the raw wastewater. At the commercial or demonstration plant scale, ammonia can be removed by steam stripping at high temperatures. This would eliminate the need for lime sludge disposal and remove more ammonia than would be removed by low temperature air stripping.

Further results 35 indicate that 95 to $99 \%$ of the ammonia in certain wastewaters can be removed by steam stripping without $\mathrm{pH}$ adjustment.

Organics Removal

Most of the research in coal gasification wastewater treatment is focused on organics removal. Organics can be effectively removed from coal gasification wastewaters using biological or chemical oxidation, carbon adsorption, or solvent extraction processes. Upstream pretreatment units are needed to remove contaminants that inhibit or that are not removed by oxidation, adsorption, or extraction processes. Pretreatment also modifies and buffers the wastewater entering bio-oxidation processes, thus preventing system upsets.

A large portion of the Total Organic Carbon (TOC) content of coal gasification wastewaters has been found to be phenolic in nature. Most subsequent research has concentrated on the oxidation of phenolic compounds and on the identification of inhibitory effects from wastewater contaminants. Wastewater samples from pilot plant and bench scale gasification processes have undergone treatability studies to determine the optimum design parameters for wastewater treatment processes.

Treatability studies for organics removal from Synthane wastewaters were done by Johnson, et al.15. At the time of these studies, wastewater from the Synthane pilot plant was not available. Wastewater samples were obtained from the Synthane Process Development Unit (PDU), which produced 120 pounds of wastewater during a normal 5-hour run time using Montana Rosebud subbituminous coal. The 
wastewater was air stripped at a $\mathrm{pH}$ of 11 for ammonia removal and treated for 0il, tar, and grease removal before biological oxidation treatment for organics removal.

The microorganisms for biological oxidation were obtained from a nearby coke plant wastewater treatment facility and acclimated to the Synthane wastewater before treatability testing. Experimental constraints necessitated fixing the detention time at 24 hours. The food-to-microorganism ( $F / M$ ) ratio was varied to maximize oxidation rates. Nutrients were added in the form of mono-and dibasic phosphates. The ammonia level was maintained below $500 \mathrm{mg} / 1$.

Steady state oxidation was achieved after four hydraulic retention times. Table 3.5 shows operating conditions during steady-state conditions. Of interest is the relative insensitivity of oxidation rates when the $F / M$ ratio was increased to 0.71 . Slight decreases in organic removals took place while the sludge volume index (SVI) fell, indicating a more settleable sludge. The SVI is a measure of sludge settlability. It is defined as the volume, in milliliters, occupied by one gram of sludge that has settled for 30 minutes. In general, values under 100 are considered acceptable, while values below 30 are excellent.

Phenol removal was relatively constant at $99 \%$ up to an $F / M$ ratio of about 0.8 , but began to $f a l l$ off at greater $F / M$ ratios. COD removals remained rather steady at about $60 \%$ up to an $F / M$ ratio of 1.0 . TOC removals remained fairly constant at about $70 \%$ up to an F/M ratio of 0.6 . At $F / M$ ratios above 0.6 , TOC removals fell rapidly, reaching $40 \%$ at an $F / M$ ratio of 1.0 . The sludge volume index (SVI) steadily decreased with increasing $F / M$ ratios to a minimum of 30 at an $F / M$ ratio of 0.8 .

Extensive treatability testing of Hygas wastewaters for organic removal by biological oxidation has also been reported.34,36 The wastewater was pretreated by blending the cyclone and quench condensates, removing excess alkalinity by lime treatment, and air stripping ammonia to residual levels of 100 to $150 \mathrm{mg} / 1$. It was found that phosphorus was required for biological growth. 
Table 3.5 Average Operating Conditions During Steady State Dxida:ion of Synthane Wastewaters*

\begin{tabular}{|c|c|c|c|c|c|c|c|c|c|}
\hline $\begin{array}{c}\text { Applied F/M } \\
\text { Ratio } \\
\text { (LB TOC,LB } \\
\text { MLVSS/DAY) } \\
\end{array}$ & $\begin{array}{c}\text { TOC } \\
\text { (mg/l) } \\
\text { Infl. Eff. }\end{array}$ & $\begin{array}{c}\text { TOC } \\
\% \\
\text { Removal } \\
\end{array}$ & $\begin{array}{c}\text { COD } \\
\text { img/1) } \\
\text { Infl. Eff. }\end{array}$ & $\begin{array}{c}\text { COD } \\
\% \\
\text { Removal } \\
\end{array}$ & $\begin{array}{l}\text { Pher } \\
\text { (mg/ } \\
\text { Infl. }\end{array}$ & \}$_{\text {Eff. }}^{1}$ & $\begin{array}{c}\text { Phenol } \\
\% \\
\text { Removal }\end{array}$ & $\begin{array}{r}\text { MLVSS } \\
(\mathrm{mg} / 1)\end{array}$ & $\begin{array}{l}\text { Sludge } \\
\text { Volume } \\
\text { Index } \\
\end{array}$ \\
\hline 0.71 & $196 J$ & 57 & $5690 \quad 2030$ & 64 & 1205 & 25 & 98 & 2750 & 30 \\
\hline 0.20 & 150 & 70 & 1250 & 69 & 175 & $\leq 1$ & 99 & 2520 & 47 \\
\hline
\end{tabular}


The stripped wastewater was treated at mean cell residence times of 10 to 40 days and hydraulic retention times of two to three days. Influent phenols were reduced from $1600 \mathrm{mg} / 1$ to below $0.5 \mathrm{mg} / 1$, while COD was reduced $80 \%$ to $800 \mathrm{mg} / 1$. Cyanide levels were not reduced. Thiocyanate removals were 80 to $90 \%$. Sludge produced by the process had acceptable SVI's in the 50 to 75 range.

Experiments run with unstripped Hygas wastewaters showed that maintaining high concentrations of ammonia $(3200 \mathrm{mg} / \mathrm{l})$ for three weeks caused biological system failure. A 1:1 dilution of the wastewater with uncontaminated water produced stable reactions.

The wastewater was found to inhibit nitrification. It was unlikely that excessive loading was the cause, because nitrification was not observed even in reactors with relatively low loadings. High concentrations of boron were suggested as the cause.

Recommended design parameters from this study are a mean cell residence times of 15-40 days, a hydraulic retention time of 3 days, alkalinity of $1000 \mathrm{mg} / 1$, and a pH between 7.0 and 7.5. Unstripped wastewater can be successfully treated only after a $1: 1$ dilution.

Stable biological reactions were also established in subsequent treatability studies 34 using wastewater from a later Hygas run. The biological reactor was operated at a hydraulic retention time of 5.4 days, a mean cell residence time of 20 days, and a MLSS of $1500 \mathrm{mg} / 1$. COD removal was $78 \%$, BOD was $80 \%$, and phenol effluent levels averaged $0.35 \mathrm{mg} / 1$ at an influent level of $650 \mathrm{mg} / 1$. It was discovered that boron levels up to $160 \mathrm{mg} / 1$ did not inhibit oxidation as was previously thought. Again, cyanide was not removed, but thiocyanate was reduced from $37 \mathrm{mg} / 1$ to $1 \mathrm{mg} / 1$ during biological oxidation. Nitrification, evidenced by both reduced ammonia levels (from 135 down to $30 \mathrm{mg} / \mathrm{l}$ ) and increased nitrate levels, was also observed in these subsequent treatability studies.

Wastewater from another later Hygas run was used to evaluate wastewater reuse treatment technology37. The wastewater was steam stripped to remove approxiInately $97 \%$ of the ammonia. Biological oxidation achieved a COD reduction of 
$16 \%$ and a thiocyanate reduction of $96 \%$. The effluent contained $1200 \mathrm{mg} / 1$ of hardness as $\mathrm{CaCO}_{3}$. This effluent cannot be directly used as cooling tower makeup because the remaining $C O D$ would promote significant biological activity and the hardness would cause scaling problems.

Most of the hardness present in the effluent is non-carbonate because alkalinity is consumed during biological oxidation. Softening required a larger portion of soda than lime, which resulted in the replacement of equivalents of hardness by sodium. Flocculation and/or filtration was necessary to clarify the sludge formed by softening. Further dissolved solids and organics removal was attempted by reverse osmosis, carbon adsorption and resin adsorption. Only reverse osmosis showed promise.

A biological treatment study of GFETC slagging fixed-bed gasifier wastewaters 38 found that ammonia-stripped wastewaters could be treated after dilution to 33\% of the initial concentrations. At 50\% dilution, extreme operational difficulties were experienced. Treatment of the $33 \%$ feed (influent diluted to $3840 \mathrm{mg} / 1$ phenol) achieved BOD removals of $95 \%$ and COD removals of $81 \%$. Phenols were reduced by greater than $99.8 \%$, thiocyanate was reduced by $89 \%$, and organic nitrogen by $55 \%$ (influent at $160 \mathrm{mg} / 1$ ). Reactor operating conditions were 10 to $40-$ day mean cell residence time and $1550 \mathrm{mg} / 1$ MLSS. The resulting sludge had a SVI index of 35 . This study used mean cell residence time as the controlling factor rather than the hydraulic detention time.

During the runs, a significant amount of nitrification took place (50 to $90 \%$ removal). It was found that nitrification was favored at COD removal rates bélow 0.4 /day.

Concern was raised over the possibility of an undetected cyanide interference with the biological reactions. Cyanide in wastewaters degrades rapidly. The cyanide levels in the wastewaters being treated in this study may have degraded to levels much lower than what would be expected during normal operal ions because of the storage times involved. Cyanide levels in GFETC wastewaters have been observed to drop from $200 \mathrm{mg} / 1$ to $25 \mathrm{mg} / 1$ in three days. Wastewaters were 
spiked with potassium cyanide to a concentration of $100 \mathrm{mg} / \mathrm{l}$ in separate tests to resolve this concern. Cyanide at this concentration did not affect biological oxidation or nitrification.

Subsequent tests showed that raw GFETC wastewater could be processed at a $40 \%$ dilution. Nitrification reactions were effective with this wastewater in reducing the ammonia concentration from $2700 \mathrm{mg} / 1$ to $1000 \mathrm{mg} / \mathrm{l}$. It was concluded that the inhibition of nitrification reactions is dependent upon ammonia loadings. Nitrification was not inhibited by influent ammonia concentrations as high as $3000 \mathrm{mg} / \mathrm{l}$.

Isolation of bacteria capable of oxidizing wastewaters from the SASOL Lurgi plant was done by M. Bromel ${ }^{16}$. Pseudomas, Arthrobacter, and Microccus bacteria were isolated from North Dakota soils and used to treat various wastewaters from the SASOL plant. The highest COD removals obtained were $70 \%$.

A combination biological and physical wastewater treatment process was investigated by M. Suidan, et al.39 at the Georgia Institute of Technology. Waste:waters containing phenol and/or glucose bearing substrates were treated in an anaerobic filter. In these filters, anaerobic bacteria grow on the filter medium and remove biologically degradable organics. In this study, activated. carbon was used as the filter medium to also remove refractory organics. The advantages of using an anaerobic process rather than an aerobic process are that the anaerobic process forms methane gas as a byproduct and that higher loading rates, lower sludge production. Hydraulic residence times of almost 12 hours reduced the $2000 \mathrm{mg} / 1$ of glucose substrate $92 \%$ with respect to TOC and $95 \%$ with respect to $C O D$. The $200 \mathrm{mg} / 1$ phenol feed first produced gas 135 days into the experiment and reached steady state conditions after 240 days. Removals at the second stage of the filter were $86 \%$ for TOC, $87 \%$ for COD, and $99.9 \%$ for TOC, COD, and phenol respectively. A final test was performed in wich the readily biodegradable and poorly adsorbable glucose was added to the strongly adsorbable pheno1. There were no antagonistic effects found. 
This type of treatment has also been investigated by $E$. Witt and W. Humphrey of the Celanese Polymer Specialties Company40. The process of the anaerobic filter is modified slightly to buffer the system with respect to toxic surges and modify the $\mathrm{pH}$ to acceptable levels. This is accomplished by diluting the feed with effluent from the filter. This recycle flow was found to improve the performance and reliability of the system. Feed concentrations of $11,500 \mathrm{mg} / 1$ of COD have been reduced by $60 \%$. In this configuration, the effluent from the anaerobic filter is then processed aerobically.

Treatability studies performed by $W$. Slack at West Virginia University 33 analyzed biological treatment of wastewaters from the METC gasifier. Tests were done to investigate the effects of dilution and detention on performance, to determine the desirability of adding powdered activated carbon, and to establish kinetic data on biological reactors.

In the first set of experiments, four samples of wastewaters were obtained from different runs to simulate different gasifier conditions. The oils and tars were allowed to separate, and sample withdrawal took place at mid-depth. This procedure simulated expected pretreatment of the wastewaters. Wastewater samples were airstripped at a pH of 11.5 for 24 hours. The ammonia concentrations dropped from $2200-3000 \mathrm{mg} / 1$ to $450-550 \mathrm{mg} / 1$. Cultures obtained from a coking plant wastewater treatment facility were used for innoculation. It was found that during bio-oxidation, the $\mathrm{pH}$ rose to 8.5 or higher and had to be controlled by addition of phosphoric acid because the high alkalinity of the wastewater caused the $\mathrm{pH}$ to rise as $\mathrm{CO}_{2}$ was stripped off. Adding lime instead of $\mathrm{NaOH}$ during ammonia stripping operations should reduce the alkalinity of the wastewater. It was found that a feed of $75 \%$ wastewater could be treated biologically. Further experiments revealed that a detention time of 4-6 days resulted in stable jerformance. Reduction of phenols and BUD was over $90 \%$, while TOC removals were above $60 \%$. Organic loadings were 0.13 to $0.47 \mathrm{gm} \mathrm{BOD/day/gm} \mathrm{MLSS.} \mathrm{MLSS} \mathrm{concen-}$ trations were around $4000 \mathrm{mg} / 1$ and the SRTs were 18 days for the 4 day reactor and 15 for the 6 day reactor. 
To evaluate the effects of powdered activated carbon (PAC) during stressed operation of the biological oxidation unit, two reactors were set up to process the same wastewater. The water was stripped of ammonia to a level below the inhibitory level $(600-1000 \mathrm{mg} / \mathrm{l})$. Full strength wastewater was processed at a 4 day detention time. At the 8-day mark, when both reactors were showing signs of biological system failure, $3000 \mathrm{mg} / 1$ of PAC were added to one reactor. The PAC reactor recovered after day 11 and eventually, at day 24 , had TOC removals of $70 \%$ and phenol removals of $87 \%$. The non-PAC reactor failed on day 13 , as noted by zero oxygen consumption. Use of PAC appeared to control process fluctuations caused by influent variations.

In unstressed conditions, a wastewater with 500-600 mg/l of ammonia was processed by a biological reactor with $6000 \mathrm{mg} / 1$ of PAC. Without PAC, the reactor functioned, but TOC and phenol removals were 55\% and 64\% respectively. The removals, upon addition of PAC, rose to $75 \%$ and $90 \%$ respectively. The PAC also seemed to control foaming problems with the reactor at higher loading rates.

Biological oxidation with PAC addition was also tested with GFETC wastewaters, processed at a 33\% dilution under conditions previously determined to be optimum. 35 Without $P A C$, the biological reactor reduced an influent BOD from 3700 $\mathrm{mg} / 1$ to $30 \mathrm{mg} / 1$. The addition of $P A C$ reduced the $C O D, B O D$, and color of the effluent relative to the run without PAC. However, based on more detailed analysis, it was found that little reduction in soluble organics was achieved by adding PAC.

An important constituent of gasification wastewaters, besides ammonia and phenol, is thiocyanate. These compounds are present in coke plant wastewaters, and it has been found that biological removal is unpredictable. The traditional method of removing thiocyanate by chlorination is not possible in this case, because the phenol also present would react with chlorine to form chloro-phenols. Results obtained through experimentation are that mixed cultures from coke plants can degrade thiocyanate from $2000 \mathrm{mg} / 1$ to $1 \mathrm{mg} / 1$ at 9 hours of detention time, and substrate inhibition takes place at thiocyanate concentrations in excess of $500 \mathrm{mg} / \mathrm{l}$. 
Biological oxidation of synthetic gasifier wastewater has been done by Singer, et al.32 at the University of North Carolina - Chapel Hill. The wastewater components were established by reviewing gasifier wastewater characteristics. The wastewater originally contained $2000 \mathrm{mg} / 1$ of phenol, and $3820 \mathrm{mg} / 1$ of $\mathrm{NH}_{3} \mathrm{CL}$, had a TOC of $4636 \mathrm{mg} / 1$, and contained inorganic buffers and nutrients. It was then diluted to $25 \%$ of its original concentration to reduce its toxicity to micro-organisms. The synthetic waste was treated in a continuous flow activated sludge system with no recycle of biosludge. Hydraulic retention times varied from 5 to 10 to 20 days.

With retention time and sludge age at 20 days, $85-97 \%$ of TOC, $86-96 \%$ of COD, and $99.8 \%$ of BOD were removed. Phenol wás removed at a sludge age as luw as 5 days. MLSS concentrations ranged about $900 \mathrm{mg} / 1$ for all reacturs.

Fluidized bed treatment of phenolic wastes was investigated by Lee, Scott, and Hancher at the 0ak Ridge National Laboratory41. In this type of treatment, the biological growth adheres to inert particles in a fluidized bed. Phenol concentrations of $260 \mathrm{mg} / 1$ were degraded to less than $1 \mathrm{mg} / 1$ in 15 minutes of detention time. The maximum feed concentration of phenul that can be degraded on a continual basis by this method appears to be about 200-300 mg/l. Degradation of other orydlics in the feed began about 14 hours after they were added. It was also found that the bioreactor was easy to operate and could be left for long periods of time unattended. At the scale tested, this process looks very promising.

Chemical oxidation of phenolic wastewaters was reviewed by Suidan, et al. 39 . Treatment processes included hydrogen peroxide, ozone, and chlorination. Hydrogen peroxide in the presence of ferrous salts has been shown to reduce phenol concentrations of $50 \mathrm{mg} / 1$ to less than $1 \mathrm{mg} / 1$ in thirty minutes. The inability of this process to efficiently remove high concentrations of phenols relegates it to effluent polishing status.

Ozonation has been shown to be an effective oxidizing agent for phenols. A survey of 10 coking plant wastewaters shows that influent phenol concentrations 
were reduced from an average of $1500 \mathrm{mg} / 1$ to $0.60 \mathrm{mg} / 1$. To achieve this removal, an ozone/phenol weight ratio of 1:41 was used. As in the case of hydrogen peroxide, the economics of this process will probably limit its use to effluent polishing.

Klein 4 in his review of treatment processes concludes that the use of ozone can only be economical when a low waste concentration is to be reduced or when a small change in the waste composition is desired. A prime example of the latter is ozonation preceding biological treatment to reduce toxic and refractory materials to biodegradable forms.

Chlorination was found not to be an acceptable oxidation process because of its tendency to form hazardous chloro-phenols.

The Synthane process produces a char as a by-product that is planned to be incinerated to generate steam. Because the char has a surface area of over 300 $M^{2} / g r a m$, its use in adsorption processes was investigated by Johnson, et al.15. The char after adsorption could then be fired to produce heat. Isotherm tests. were run using Montana coal chars and biologically treated Synthane process wastewaters.

Adsorption tests were run and an isotherm was established for the char. Column tests were then performed to evaluate removal efficiencies. The phenol concentration into the char column was generally less than one $\mathrm{mg} / \mathrm{l}$, and the effluent from the char column contained no phenols to the detection limits of GC-Mass Spectrometry methods. Color in the wastewater was also el iminated with char adsorption. Non-biodegradable TOC was reduced by about $90 \%$ by use of char adsorption.

Experiments were performed 37 in which stripped, biologically treated, and sof tened Hygas wastewater was treated in an activated carbon adsorption column. The influent was maintained at a pH of 7.0 , and the carbon column provided a contact time of 17 minutes at a loading of $1.2 \mathrm{gpm} / \mathrm{sq}$. $\mathrm{ft}$. The results indicated that $80 \%$ of the $\operatorname{COD}$ and $95 \%$ of the color could be removed by carbon adsorption. 
Hygas wastewater treated as above was considered to be of sufficient quality for use as cooling tower makeup. Without data on TDS for the effluent, it seems premature to reach such a conclusion. It was assumed that the biological growth resulting from the residual COD of about $100 \mathrm{mg} / 1$ could be effectively controlled by a biocidal program.

Further analys is by Vajda 42 of these data resulted in the conclusion that carbon adsorption in this case is economically impractical without regeneration because of the large quantity of carbon usage. It was estimated that, at present prices for activated carbon, the cost for treatment without regeneration would be approximately $\$ b 2$ per thousand gallons. If the carbon is thermaliy regenerated, the carbon loss will drop to approximately $5 \%$ of the usage, which would make the process cost effective.

Phenol removal was investigated 43 using toluene, isopropyl ether, and n-butyl acetate. Because most solvent extraction processes are proprietary, obtaining their solvents to test removal efficiencies is not feasible. It was found that Hygas quench condensate phenol removals, using a five-step extraction process, paralleled removals found in the proprietary processes. The wastewaters pretreated by solvent extraction removed $99 \%$ of the phenolic compounds, or about $75 \%$ of the COD. Subsequent biological oxidation removed $78 \%$ of the remaining COD. The pretreated effluent contained more refractory materials because the easily oxidizable phenols were removed by solvent extraction. Wastewaters pretreated by solvent extraction also had a decreased tendency to foam during aeration.

Phenol removal from Hygas quench wastewaters was tested, using amberlite resins in a resin adsorption column. The process was ineffective, due to the large quantity of regeneration wastewater evolved.

Ozone treatment of Synthane wastewaters in a bench scale unit was performed by R. Neufield and A. Spinola at the University of Pittsburgh 44 . Wastewater obtained from the bench scale Synthane plant was contacted countercurrently with the ozone in a packed adsorption tower. The results of the tests run were 
that marginal removals were obtained at rates as 1 ow as $25 \mathrm{ml} / \mathrm{min}$ of wastewater at a dosage of $74 \mathrm{mg} / 1$ of ozone.

\section{Dissolved Inorganics Removal}

Klemetson and Scharbow 45 have experimented with reverse osmosis (RO) and ultra- filtration to reduce pollutants in a synthetic representation of Lurgi wastewaters. The zirconium oxide-polyacrylic acid RO membrane had a maximum phenol rejection rate of $80 \%$ at a $\mathrm{pH}$ of 10 . The feed was $100 \mathrm{mg} / \mathrm{l}$ each of phenol, catechol, resorcinol, and 0 -cresol. The salt rejection rate was greatest (92\%) near a neutral pH. This characteristic is beneficial if phenol concentrations are required to be reduced without removing all the salts from the wastewaters. Long-term effects of the wastewater on the membrane were investigated for runs of 60 hours. During this period, the flux rate stabilized at $150 \mathrm{gal} / \mathrm{day} / \mathrm{sq} \mathrm{ft}$ with no further deterioration.

Ultrafiltration runs showed rejection rates similar to Ro membranes. Tempera:ture caused significant variations in the flux but little change in rejection rates for some ultrafiltration membranes. For the zirconium oxide membrane, the flux increased by over 2-1/2 times to $160 \mathrm{gal} / \mathrm{day} / \mathrm{sq} \mathrm{ft}$ as the temperature increased from $75^{\circ} \mathrm{F}$ to $130^{\circ} \mathrm{F}$. The flux rate al so increased with increasing pressure. No observable long-term deterioration of either type of membranes was caused by the feed water.

Experimentation by Vajda 42 using RO to treat biologically processed Hygas wastewaters found that significant deterioration of a polyamide membrane had occurred in two weeks. The efficiency of preventing the passage of dissolved solids was reduced by a factor of seven for one and ten for another membrane. In addition, it was found that the feed became saturated by calcium sulfate at $50 \%$ water recovery. Attempting to recover more water would precipitate out the calcium sulfate, fouling the membrane. The high turbidity of the wastewater al so caused membrane fouling. 
Lime/soda softening was investigated as a means of removing calcium sulfate in a pretreatment step prior to RO. Although more lime and soda than expected were required, this step did remove calcium sulfate to acceptable levels. Tests also showed that phenols were reduced by $40 \%$ and total COD by $15 \%$ by $11 \mathrm{me} / \mathrm{soda}$ softening.

Work done by Chu, et al.46 provides information on the use of lime/soda softening to remove dissolved metals from powerplant bottom-ash effluent. The purpose of this treatment was to investigate the reusability of the wastewater. Results indicate that 1 ime/soda softening effectively removes Lurbidity, calcium, magnesium, and silica. The addition of soda ash was required because of non-carbonate hardness. If the system was operated in a water reuse mode, sulfate buildup could be controlled by the addition of excess lime. Raising the pH to 10 with lime addition removed over $90 \%$ of the cadmium, copper, iron, lead, and zinc in the power plant effluent.

Preliminary results reported have indicated that a hollow fiber polyamide membrane operated at 400 psi and $25 \%$ recovery produced a high quality permeate, with about $20 \mathrm{mg} / 1$ COD passing through the membrane. 35

The addition of a polyphosphate inhibitor was thought to have prevented observable fouling. A decline in membrane flux did occur, but it was attributable to membrane compaction. The polyamide resin was compared to the cellulose triacetate hollow fiber membrane; the polyamide membrane produced a higher quality effluent, but higher flux rates were provided by the cellulose membrane.

Further work on long term membrane effects caused by fouling and on membrane cleaning techniques is being done at the present time. 


\subsection{DATA GAPS}

A review of the data base showed gaps that require investigation. The information gaps are as follows:

1) Little work has been done synthesizing a complete treatment train. Rather, the same wastewater is being used to investigate different processes that would normally be connected in series. This does not allow potential problems in interfacing these processes to surface.

2) Advanced treatment processes have not been shown to eliminate refractory organics. With a recycled wastewater, a consistent method of removing these organics must be found. A possible choice for processes would be some form of pretreatment prior to biological oxidation to reduce refractory organics to biodegradable form. Ozonation has been shown to be effective for this pretreatment. Reverse osmosis is another potential treatment process that could be perfected. Other tertiary processes should be investigated to remove these refractories.

3) Operational problems encountered in $100 \%$ recycle systems should be explored. The buildup of various substances with time must be prevented to eliminate possible upsets to a biological or other process.

4) The form and severity of the effluent regulations for these plants is a data gap because there is no indication of what they will be. A $100 \%$ recycle design is obviously the most stringent design requirement.

5) The largest data gap is the absence of studies performed on a steady state gasifier producing enough wastewater to be treated on an as-produced basis. This gap will not be filled until the demonstration plants come on line. 


\subsection{DESIGN CONSIDERATIONS}

General recommendations for design considerations of a coal gasification wastewaters treatment system are summarized in the following paragraphs. These recommendations are proposed to aid engineers in selecting a suitable technology to design and in reviewing and evaluating the adequacy of a treatment scheme once it is designed. They are grouped in six categories of wastewater sources: coal pile storage and runoff, domestic sanitary wastes, solid waste leachate, ash quench, raw water treatment discharges, and process/gasifier quench condensates.

\subsubsection{Coal Pile Storage and Runoff}

A. All coal storage piles should be made impervious to infiltration and all pile run off should be collected and treated.

B. The decision to recycle or discharge treated runoff should depend on the climatic conditions, net plant water availability, the accessibiity of water reuse facilities, and areas of potential discharge.

C. Simple containment, lime addition, and possibly aeration should be the only processes needed prior to discharge.

D. Containment and treatment for several days should be provided in the design.

E. NPDES permits should be obtained regardless of plant design and reuse.

F. 0 il removal should not be necessary for this wastewater source.

G. Depending on the total dissolved solids (TDS) content of the runoff, consideration should be given to blending with cooling tower blowdown for further treatment. 


\subsubsection{Domestic Sanitary Wastes}

A. Domestic sanitary systems should be completely segregated, if possible, from the process wastewater treatment system.

B. The domestic wastewater system should be plumbed and sized for the construction workforce.

c. The plant should be sized for construction of the commercial facility.

D. The discharge or reuse of treated domestic wastes should be evaluated as 3.4.1B.

E. Chlorination should be avoided, if possible, for final bacteriological control. Ozonation, UV, or other should be used.

F. NPDES and state permits should be obtained regardless of plant design.

G. Laboratory facilities solely for the domestic wastewater system should be supplied.

\subsubsection{Leachate Water Quality Control from the non-RCRA Solid Wastes Disposal Area}

A. Surface and groundwater quality monitoring should be conducted for the duration of the demonstration operations.

B. The disposal area should be designed as a small area that can be expanded as operational data indicate the need. The incremental size should be for 6-month periods. Containment, control, and changes in water quality should be monitored for the individual disposal units.

C. Onsite surface and leachate wastewater treatment should consist of, as a minimum, collection, detention, quality analysis, and bleeding to other 
treatment facilities if the quality is insufficient for direct surface water disposal.

D. NPDES permits should be secured for direct surface water disposal following treatment, if necessary.

E. The reuse of leachates would be analyzed as per 3.4.1B.

F. The concept of zero discharge from this wastewater source is not valid, since this is a perpetual source of wastewater even if the plant is shut duwii, liullibdlied, or decommisstoned. NFUES permits should be secured.

G. Unless otherwise noted, oil removal treatment would not be a part of this wastewater stream treatment.

\subsubsection{Ash Quench Wastewater}

A. Ordinarily this wastewater will be completely recycled in the slag quench process area.

B. If small blowdown streams are required, the streams would be carefully bled from this area and discharged into the product gas quench wastewater stream.

C. Slag quench wastewater makeup should be the first area within the plant where water recycling is used. It is, therefore, desirable to recycle the cooling tower blowdown to the gasifier slag quench area.

\subsubsection{Raw Water Treatment Aqueous Discharges}

A. The sludge treatment dewatering waste streams from the potable and process water supply plants should be considered as a wastewater source in all plant designs.

B. The demineralizer wastewater stream should be considered in all wastewater treatment plant designs. 
C. Treatment and direct disposal of these non-process contaminated waste streams would be preferable to possibly contaminating them by treatment in the main process wastewater treatment system.

\subsubsection{Process/Quench Condensates}

A. Enough equalization capacity (e.g. 2 days) should be provided to damp out potential toxics loading fluctuation caused by process upsets.

B. Prior to ammonia/phenol removal and further waste treatment steps, consideration should be given including some kind of emulsion breaking steps, e.g., pH adjustment.

C. Using two different treatments in sequence rather than relying on one treatment only to treat high organically contaminated wastewater can be most cost effective.

D. Lime-soda can be effective in inorganics removal; countercurrent regenerated ion exchange should be considered when a concentrated waste stream is preferred to a higher volume dilute waste; reverse osmosis should be considered when a dilute waste stream with a minimum salt content is preferred.

E. Forced evaporation of wastewater should be considered as the last resort inorganics removal step.

F. Treated water should be reused to its maximum extent rather than discharged; decision of reuse or discharge should be evaluated per 3.4.1.B.

G. NPDES permits should be obtained in all cases. 


\section{SECTION 4 - INDUSTRIAL WASTEWATER TREATMENT PROCESSES}

\subsection{INTRODUCTION}

Most coal gasification technologies are still in the pilot plant or bench scale stage. Operating times are on the order of hours or weeks. Steady-state operation is too short for adequate characterization of wastewaters or wastewater treatment system operation. Pilot plant and bench scale operation is used more for trouble-shooting processes than for characterizing wastewaters and other environmental factors.

This section describes the function, applicability, efficiency, and reliability of various wastewater treatment unit processes operating at commercial site and at steady state. Both conventional and unconventional technologies are analyzed. The analyses of conventional wastewater treatment technologies rely on the operating experience of a variety of industrial applications. The impact of current and evolving effluent standards on the design of gasification facilities and approved instrumental methods for wastewater characterization are also presented in this section.

Wastewater treatment processes for industrial wastewaters are evaluated in terms of removal efficiencies, reliability, and resistence to upsets. Alternative processes within each unit operation must be analyzed to determine the most efficient method to remove the projected pollutants. The critical impact of upstream processes and the critical requirements of downstream processes in a complete wastewater treatment system require a system analysis that is considerably more complex than analyses of the performance of the individual processes in the system. At the demonstration scale, the primary design criteria must include reliability and resistance to overall system upsets and failures. It should be the purpose of the demonstration plant to prove the reliability and effectiveness of the wastewater treatment system design.

No single process can remove all the pollutants to environmentally acceptable limits or process reuse requirements. Therefore, it is necessary to combine 
various processes to effect the desired treatment. The required treatment will be dictated by reuse water specifications and discharge requirements. The selection of the processes should be based upon meeting those effluent constraints in the most cost effective manner. The wastewater may contain impurities in sufficient quantities to make recovery and resale economical, which could influence the treatment selections.

\subsection{TREATMENT PROCESS DESCRIPTIONS}

Contaminants in wastewater can be removed to meet discharge or reuse require= likents by converting them to other forms or by separating them for recovery or disposal. Many organics in wastewaters can be converted by chemical or biological treatment processes to produce biosludge and/or carbon dioxide or methane, depending upon the wastewater composition and the treatment process. Phenols, ammonia, and other dissolved weak electrolytes can be stripped from wastewaters and recovered. Tars and oils can also be separated and recovered. Dissolved strong electrolytes can be separated from wastewaters by such processes as reverse osmosis, electrodialysis, ion exchange, and evaporation and disposed in a concentrated aqueous solution, a slurry, or a solid waste.

Treatment of gasification wastewaters can be broken into several discrete operations. These operations are $0 i l$ and suspended solids removal, dissolved gas. removal, dissolved and suspended organics removal, and dissolved inorganics removal. The treatment processes available within each section are varied, and the choice of which process to use will be dependent upon many factors. Factors to be considered are process efficiency, effluent targets, cost effectiveness, reliability, and resistance to process upsets. The following is a description of available treatment processes that are available for treating gasification wastewaters.

\subsubsection{0 il and Suspended Solids Removal}

One of the first steps in treating wastewaters from gasification plants is oil and suspended solids removal. Gas quench water (which at this stage has usually been treated for the recovery of tars/oil, ammonia, and phenols) will undergo 
coarse removal of settleable solids and floating oils because these materials will clog and coat downstream process mechanisms.

0il and suspended solids removal, in some cases, allows the wastewater to be reused directly after treatment or decreases the load on a downstream unit. The major processes used are gravity separation, flocculation-flotation and flocsedimentation. Another process, filtration, is normally used as an effluent polishing step.

\section{Gravity Type Separators}

The most well known gravity separator is the API unit, which is designed in accordance with standards adopted by the American Petroleum Institute (API). The separator is essentially a basin in which solids heavier than water settle to the bottom and oil globules lighter than water float to the top. A collector skims the oil off the water surface and scrapes the sludge off the bottom. The collected oil is sent to a recovery unit and the solids or sludge is dewatered and disposed of.

These units will, in general, remove $60-99 \%$ of the separable incoming oil, $50-80 \%$ of the suspended solids, $5-35 \%$ of the BOD, and $5-30 \%$ of the COD, depending upon the wastewater. This process provides coarse treatment and is usually followed by other processes that remove solids and oils to acceptable levels. The treatment efficiencies are affected by the temperature of the wastewater (the temperature determines the viscosity, the density, and the size of oil droplets, all of which affect rise velocity) and the types of solids in the wastewater. The process advantages are high reliability (derived from extensive use in the petroleum industry), low energy consumption, and that it is a simple and effective process to remove grit, heavy suspended solids and non-emulsified or separable oils from wastewaters. Disadvantages of the process are the large amount of space the units require, the fact that it is only a coarse treatment process requiring further treatment, and that it is only effective on high concentrations of non-emulsified oils. 
Flocculation-flotation

This process is generally used in conjunction with, or in lieu of, gravity separators for the removal of dilute quantities of oils and suspended solids. To overcome electrostatic repulsion of suspended solid and oil particles so that they may agglomerate and be removed more rapidly, coagulants are added to the wastewater. These chemicals allow the charged colloidal particles to come close enough to contact each other through a reduction in surface charge on the particles. After chemicals are added to the wastewater, it is gently stirred (flocculated) to bring the particles close enough to contact each other and torm groups or flocs.

Flocculated wastewater is then sent to the flotation unit, where gas injected at the bottom of the unit rises, intercepting solids and oils, and carries them to the surface, where they are removed by a skimmer. Flocs of solids and oils will intercept more rising gas bubbles in the flotation unit and rise faster than non-flocced solids and oils. Flotation can be accomplished by injecting air through diffusers in the bottom of the tank. Another type of flotation is dissolved air flotation (DAF) in which a sidestream, or the entire wastewater flow, is pressurized, injected with a gas (usually air) that is al lowed to dissolve in the pressurized water, and then introduced into the bottom of the tank. The pressurized water, on exposure to atmospheric pressure, evolves the dissolved gas in the form of small bubbles, which rise to the surface. The rising bubbles entrap particles as they rise and carry them to the surface.

Flocculation-flotation systems can achieve the following removal efficiencies: $10-60 \%$ for $B O D, 10-50 \%$ for $C O D, 50-70 \%$ for suspended solids, up to $75-95 \%$ for separable 0 ils, and 50-70\% for emulsified oils. These removal efficiencies may not be as high as stated for some wastewaters because different components may contribute to $C O D$ and $B O D$.

Because of the ionic nature of the process, the main disadvantage of the system is its high sensitivity to temperature, $\mathrm{pH}$, and hydraulic loading variations in the incoming wastewater. This can be solved by the use of an equalization 
basin to dampen any fluctuations in influent characteristics, but it is still an operating problem that must be considered. The advantage of the process is the high removals of $B O D, C O D$, and oils. This unit plus an API separator can reduce highly polluted wastewaters to water suitable for biological oxidation.

Flocculation-Sedimentation

Flocculation-Sedimentation is similar to the flotation process just described except in the way solids are removed from the wastewater. In flotation, dissolved gases lift the floc to the surface. In this process, the floc formed is allowed to settle in a clarifier. The removal efficiencies of the sedimentation and flotation processes after floccuation are similar.

The advantage of flocculation-sedimentation is that it is a very simple process with few moving parts. Its disadvantages are that the process requires more space than a dissolved air flotation (DAF) unit and the solids withdrawn from the bottom of the clarifier are more dilute than the solids from a DAF unit.

Filtration

When very high removal efficiencies are required for suspended solids or oil, conventional treatment can be followed by filtration through a bed of granulated inert material, usually anthracite, sand, or diatomaceous earth. Suspended solids and oils are retained within the filter bed and gradually fill up all interstatial spaces in the bed. When the head loss across the bed is large enough, it is backwashed to remove retained particles. During backwash, the trapped particles separate and flow out with the backwash water as the bed is fluidized through agitation. The cleaned filter bed is then drained and is ready to be returned to service.

There are two main types of filtration, gravity and pressure. The deciding factor on wich type of filter to use is the solids concentrations in the wastewater. The length of time a filter is in service is a function of the wastewater flow, solids concentrations, and filter bed volume. A pressure filter 
is normally used to treat a waste stream low in solids. Pressure filters have a much higher flow capacity than gravity filters because of the higher differential across the bed. However, a solids concentration in excess of $50 \mathrm{ppm}$ will blind a pressure filter's bed so rapidly that the filter may be frequently out of service. If a high solids concentration is to be treated, a gravity filter, having a large bed volume to absorb the solids, should be used.

As a polishing step for an API separator, the following removal efficiencies can be obtained by a sand filter: 80-99\% suspended solids, 50-80\% free 0il, 25-40\% COD, and 35\% BOD. Filtration is relatively insensitive to temperature, easily maintained, relatively inexpensive, and has been successfully used to treat gasification wastewaters at the SASOL Gasification complex in South Africa. The process limitations are that the process functions best as a polishing step, the filter bed must be periodically regenerated by backwashing, and the backwash water must be treated prior to disposal.

\subsubsection{Dissolved Gas Removal}

Gasification wastewaters typically contain high concentrations of dissolved gases such as ammonia, carbon dioxide, and hydrogen sulfide. Many of these gases require removal to prevent lethal concentrations from reaching downstream biological treatment processes. In some cases, the concentrations of gases are sufficiently high to make recovery processes economical.

\section{Stripping}

Slripping of gases from wastewaters takes place when a stripping medium, such as steam or air, is forced countercurrently through the wastewater, commonly in a packed tower or a tray tower. The gases are transferred frin the wastewater into the stripping medium. Steam is the most common stripping medium and is widely used in the petroleum industry for the treatment of sour waters containing ammonia and/or hydrogen sulfide. 
Hydrogen sulfide $\left(\mathrm{H}_{2} \mathrm{~S}\right)$ can be removed from gasification wastewaters by stripping with a small quantity of steam. Wastewater to be treated is preheated to almost stripper temperatures and then poured down a coarse packed column. Steam flows upward, removing $\mathrm{H}_{2} \mathrm{~S}$ from the wastewater. Steam rates necessary to achieve $\mathrm{H}_{2} \mathrm{~S}$ removal with minimal ammonia stripping is about 0.5 pounds of steam per gallon of waste. The $\mathrm{H}_{2} \mathrm{~S}$ laden steam is then conveyed to sulfur recovery.

Ammonia present in gasification wastewaters exists in two forms, free and fixed. In the free form, ammonia molecules are weakly bonded to other molecules such as carbon dioxide and phenol. The fixed form consists of ionic ammonium ions. In the stripping process, weakly bonded free ammonia is removed first from the wastewater. The fixed form can be removed by the addition of $\mathrm{NaOH}$ or lime to a $\mathrm{pH}$ of about 11. The high pH shifts the equilibrium constant so that the ammonium ions are converted to molecular ammonia. Ammonia reductions from $4000 \mathrm{ppm}$ to about $50 \mathrm{ppm}$ of $\mathrm{NH}_{3}$ have been obtained using about 1 pound of steam per gallon of waste with appropriate $\mathrm{pH}$ control.

Stripping of dissolved gases can achieve the following removal efficiencies: $\mathrm{H}_{2} \mathrm{~S} 99 \%, \mathrm{NH}_{3} 99 \%$, phenol 20-40\%, and hydrogen cyanide up to $90 \%$. The disadvantages of steam stripping are that the efficiency is dependent upon steam rates, . $\mathrm{NH}_{3}$ and cyanide removal is sensitive to $\mathrm{pH}$, and hydrogen sulfide in stripper water is corrosive.

\section{Chevron WWT Process}

This patented process strips and recovers hydrogen sulfide and ammonia from wastewaters. In this process, the differences in solubilities of $\mathrm{H}_{2} \mathrm{~S}$ and $\mathrm{NH}_{3}$ at different pressures are used to remove the impurities for recovery. The gas evolved can be processed to convert the ammonia to anhydrous or aqueous solutions and to convert the $\mathrm{H}_{2} \mathrm{~S}$ to sulfur. Sales of sulfur and ammonia byproducts are expected to offset the higher cost of this process over conventional steam stripping." This process can achieve better than a $99.9 \%$ removal of $\mathrm{H}_{2} \mathrm{~S}$ and a $99.99 \%$ removal of $\mathrm{NH}_{3}$. The flexibility of the process allows for lower removal efficiencies, if required, with lower steam usage and correspondingly 
lower cost. The main disadvantages of this process are that it has not been used on coal gasification wastewaters, phenol recovery is low, and, because it is a proprietary process, royalties must be paid for its use.

\section{USS Phosam W Process}

This proprietary process removes contaminants present in sour wastewaters and recovers $\mathrm{NH}_{3}$ for resale. The process uses phosphoric acid phosphate salts to recover ammonia from wastewaters. Sour gases, mainly $\mathrm{H}_{2} \mathrm{~S}$ and $\mathrm{CO}_{2}$, are also removed. Ammonia removal and recovery efficiencies will normally range between 98 and 99.5\%. These efficiencies can, depending on desired outputs, be decreased or increased. $\mathrm{H}_{2} \mathrm{~S}$ removal is expected to be in the same range as $\mathrm{NH}_{3}$. The process has been commercially operating in coke ovens for over 10 years with a service factor of $95 \%$.

\subsubsection{Dissolved and Particulate Organics Removal}

Coal gasification wastewaters contain high levels of organic contaminants. The major component of the Total Organic Carbon (TOC) in gasification wastewaters is phenols. A wide variation in concentrations of many other organic compounds can be expected.

The treatment processes discussed below will most likely form the core of any system to treat coal gasification wastewaters. At this step, most of the organic pollutants are removed. The processes to accomplish this include biological oxidation for removal of biodegradable organics, chemical oxidation for removal of biodegradable organics, chemical oxidation for the destruction of refractory or non-biodegradable organics, carbon adsorption for the removal of refractory organics, and solvent extraction for phenol removal.

\section{Biological Oxidation}

Biological oxidation is the process in which living microorganisms consume dissolved and colloidal organic molecules. In aerobic processes, the bacteria 
use oxygen to convert the organic material to more cellular material, carbon dioxide, and heat. These reactions are usually carried out by a heterogeneous mixture of organisms. In anaerobic processes, the conversion of organics to cell matter and other constitutents takes place without the presence of oxygen. This process is dependent upon a few specific types of bacteria. The byproducts of this type of conversion are cell matter and methane. Aerobic treatment is preferred because of higher efficiencies and lower costs. With either type of process, the wastewater pollutants are converted into gases and a settleable mass of dead and living organisms.

Some organic materials, termed refractory, are not amenable to biological degradation. These compounds will have to be oxidized chemically or removed from the wastewater by other processes. Most of the data available for gasification wastewaters indicate that a large portion is biodegradable, however.

To maintain aerobic oxidation, oxygen and oxidizable substrates must exceed certain values. Conversely, there are maximum concentrations of some substrates for example, phenol and ammonia - above which biological oxidation is not possible. Phenol, although readily biodegradable, begins to limit oxidation at concentrations above $1000 \mathrm{mg} / \mathrm{l}$. Ammonia becomes toxic to bacteria above 600 $\mathrm{mg} / \mathrm{l}$. To treat wastewaters exceeding these concentrations, either the wastewater must be pretreated before biological treatment or the incoming wastewater must be diluted to achieve acceptable influent concentrations.

The two types of aerobic treatment processes utilized are fixed film and suspended growth. Both types have advantages and disadvantages. Fixed film processes are used for roughing operations and first stage biological treatment. The fixed film is more resistant to physical and chemical shock than are suspended growth systems. Fixed film systems also produce less biomass per unit of $B O D$ removed, and the sludges produced are more compact. Examples of this type are trickling filters and rotating biological contactors.

Suspended growth systems are generally capable of higher removal efficiencies for BOD, COD, nutrients, metals, and dissolved organics than fixed film systems. 
In this process, the bacteria are suspended in the wastewater. 0xygen is continually dissolved into the water by using diffusers or mixers. Since the bacteria are in suspension, their entire surface area can contact and degrade organics. In the most common example, activated sludge, the aeration tank effluent is sent to a clarifier, where the bacteria settle to the bottom. From the bottom, most are recycled back to the aeration reactor, with a small portion being disposed of. Recycling of solids is necessary, in this case, to keep the bacteria at the average age where maximum growth occurs, even though the hydraulic residence is much less. This ensures that substrate consumption is maximized. Other examples of suspended growth include aerated lagoons and oxidation ponds.

The process is sensitive to temperature, $\mathrm{pH}$, oxygen content, organic and hydraulic loadings, toxic material content, and nutrient concentrations. Opt imum temperature for biological growth ranges from 60-100 $\mathrm{F}$. Activity increases as temperature increases but, above $100^{\circ} \mathrm{F}$, the organisms are adversely affected and the process is upset. The $\mathrm{pH}$ level of waste stream is the most important factor influencing the efficiency of biological oxidation. These organisms cannot exist at pH levels below 5.5 or above 9.5 , with 7.0 being optimum for growth.

The presence of oxygen is required for aerobic biological growth, and the more oxygen available, the better the process is able to withstand shock organic loadings. Biological oxidation is highly dependent upon both organic and hydraulic loadings. As the organic loading increases, the percent of organics oxidized decreases but the total anount oxidized increases. The optimum feed to micro-organism ratio is 0.2-0.5:1.0. Excessive hydraulic loading results in a decrease in the efficiency of biological oxidation. The presence of heavy metals can have adverse effects on the efficiency of oxidation, particularly if a rapid change in concentration occurs. Nitrogen and phosphorus must be present for biological oxidation to occur. In gasification wastewaters, phosphorus is sometimes required as a nutrient.

Process advantages of biological treatment are that effective reductions in $B O D$ and phenol concentration can be obtained. In addition, wide applicability and 
reliability have been proven in numerous industrial applications. It is comparatively inexpensive, will remove some amounts of heavy metals, and can be designed to remove significant amounts of ammonia and cyanides from influent streams.

The disadvantages of the process are its sensitivity to $\mathrm{pH}$, temperature, shock hydraulic and solid loadings, toxics, nutrients, and oxygen. This process must be monitored carefully to prevent upsetting the reactor, causing process shutdown.

Chemical Oxidation

Chemical oxidation processes use oxidants such as chlorine compounds and ozone for the treatment of cyanide, sulfide, and thiocyanate wastes.

Ozone is a very strong oxidizing agent that is used to oxidize hydrocarbons and other organics to less complex compounds. Ozonation can proceed to complete oxidation, resulting in inert compounds such as water and carbon dioxide. Thio-: cyanate oxidizes to sulfate and cyanide, with the cyanide oxidizing slowly to cyanate. The destruction of phenols requires about 2 pounds of ozone per pound of phenol.

Theoretical energy consumption to produce ozone is about $34 \mathrm{kcal}$ per gram-mole produced. However, actual operating experience has found that the value is 20 times that figure. The low efficiency and high cost is a major drawback to the use of ozonation for the destruction of large amounts of organics.

$\mathrm{Chl}$ orine compounds have historically been used for disinfection of wastewater and drinking water. In these applications, low concentrations of bacteria are removed because of the toxic effects of chlorine on the bacteria. The ability of an installation to treat large concentrations of organics, principally phenols, is highly questionable. Chlorine reacting with phenol will produce chlorophenols, which have been determined by the EPA to be hazardous chemicals, as are phenols. 
The potential application of chemical oxidation of gasifier wastewaters will probably be limited to effluent polishing. Even with polishing applications, the required ozone dosage can be high, and ozonation may not be cost competitive with more conventional treatment processes.

\section{Carbon Adsorption}

The adsorption of dissolved organics on activated carbon is a well developed process. This type of treatment has been used for treating industrial wastewaters and as a final effluent polishing step for municipal wastewaters. Adsorption by activated carbon involves the accumulation of substances on the surface of the carbon.

To form activated carbon, organic material such as coal or wood is pyrolyzed to a carbonaceous residue. During the activation step, the carbon particles are treated so that pores are formed throughout the particle. The pore sizes generally range from 10-1000 angstroms. Estimates of the amount of surface area that activated carbon has are that one cubic foot of activated carbon has a surface area of about 10 square miles. The large surface area coupled with pores throughout the particles make activated carbon well suited for dissolved organic removal. The production of char by some gasification processes may be an advantage in that the char could be substituted for activated carbon.

Adsorption from wastewaters onto activated carbon requires that the dissolved organics being removed from the wastewater have two properties. One is a low sulubilfty of the solute being removed in the wastewater. The solute must also have a high affinity for activated carbon. If a solute has these two properties, it will be adsorbed by activated carbon in three steps. First, the solute must come in contact. with the surface film of the carbon particic's. The solute must then diffuse through the film to the surface of the carbon. In this step, the solute enters the pore matrix within the particle. The final step is the adsorption of the solute on the carbon surface. The adsorption is thought to be by chemical bonding, or electrical attraction of the solute to the carbon, or because of Van der Waals attractive forces. 
Carbon adsorption normally takes place in a packed bed of granular carbon, with either upward or downward flow. To expose all surfaces to the solute, upward flow can be increased to the point where the bed becomes fluidized. Under these conditions, each carbon particle is suspended in the wastewater with minimal contact with other carbon particles. Activated carbon can also be used in powdered form where granular carbon will not work. An example is the addition of powdered activated carbon (PAC) to the activated sludge process. Here PAC is suspended in the wastewater to remove non-biodegradable organics. PAC could also improve the efficiency of an activated sludge system by enhancing the bioactivity and improving the settleability of biomass.

As adsorption takes place, the pores on the surface fill up, and eventually the carbon particle is in equilibrium with the wastewater. In a packed column, this saturation line moves through the bed co-currently with the wastewater flow. When the bed is completely consumed, breakthrough occurs, and the carbon must be regenerated. Regeneration is the heating of the carbon to temperatures sufficient to volatize the adsorped organics from the carbon. For heavier organics, temperatures up to $2000^{\circ} \mathrm{F}$ are necessary to remove them from the carbon.

The advantages of activated carbon are its ability to purify wastewaters of refractory materials and its insensitivity to organic, toxic, or hydraulic loadings.

Because of the high cost of activated carbon, its use is restricted to the removal of high levels of toxic or refractory materials, removal of residual organics from biologically treated effluents, or for recovery of byproducts such as phenols. In some cases, activated carbon can be used in combination with other chemical-physical processes as a treatment system.

The main disadvantage of this process is the high cost of the activated carbon. This makes it necessary to thermally regenerate it for re-use, and this process is also an expensive proposition. The regeneration will also produce liquid and gaseous streams that must be treated to environmentally acceptable levels. 
Solvent Extraction

The use of solvent extraction for coal gasification wastewaters is used primarily to recover phenols for resale. Some gasification processes may produce phenols in concentrations high enough to make recovery economical. When used, solvent extraction processes precede wastewater treatment and ammonia recovery. Solvent extraction is based on the principle that phenol is more soluble in some liquids than in others. The ability of this process to function correctly requires the selection of a solvent in which the phenol is much more soluble than in the wastewater. In addition, the wastewater must not be soluble in the solvent.

Most solvent extraction processes for phenol recovery are proprietary. They include Phenosolvan, Chem-Pro, and Benzene-caustic. The use of the word phenol implies monohydric phenols, such as phenol, cresol, and xylenol, and polyhydric phenols, such as catechol and resorcinol. The distribution of these compounds depends upon the coal being gasified and the type of gasification process used. In general, monohydric compounds constitute as much as $85 \%$ of the organics present in gasification wastewaters, polyhydric compounds account for up to $34 \%$. Phenols recovered for resale must be further refined to separate the different components.

The Phenosolvan, Chem-Pro, and Benzene-caustic processes are basically similar, with the major difference being the type of solvent used. The phenol-bearing wastewater is usually pumped to a solvent contact reactor. Here the wastewater is completely mixed with the solvent, which extracts the phenol from the wastewater. The phenol-rich solvent is separated from the wastewater by difference in densities. The wastewater is stripped in a packed column to remove any solvent carryover and then pumped to further treatment.

The phenol-rich solvent is distilled to separate the components. The solvent is recovered overhead, condensed, and recycled back to the process. The phenols are recovered from the bottom of the column. This stream can either be directly taken as a byproduct or be distilled further into separate components for resale. 
The Phenosolvan and Chem-Pro processes remove about $99.5 \%$ of the monohydric, and $60 \%$ of the polyhydric phenols. They also remove $15 \%$ of other organic compounds. Both processes are reliable, having been in operation for over 20 years. The advantages of these processes are that the removal of phenol, which in most cases is necessary, can be accomplished so that the phenol can be recovered and sold. The disadvantage of the process is that the initial cost is substantial. This disadvantage can be offset by the sale of the phenol compounds.

\subsubsection{Dissolved Inorganics Removal}

A desired end use of treated gasification wastewater would be as a recycle flow back to the process. This reuse may be dictated by effluent restrictions that force a zero-discharge constraint on the plant or by economics of the plant's water consumption: The continued recycle of water within the plant will cause a buildup of dissolved inorganic compounds that must be removed.

Concentrations of these materials are reduced only slightly by the previously mentioned treatment processes. This, together with additional waste streams high in dissolved solids, such as boiler blowdown, will raise concentrations of these solids beyond acceptable limits.

To reduce this buildup of dissolved solids, either the entire recycle flow or selected streams high in dissolved solids must be treated. Treatment processes available include ion exchange, reverse osmosis, distillation, evaporation, and ultrafiltration.

\section{Ion Exchange}

Ion exchange is the process of exchanging objectionable ions ( $\mathrm{Ca}^{++}, \mathrm{Mg}^{++}, \mathrm{Fe}^{++}$) for non-objectionable ions $\left(\mathrm{H}^{+}, \mathrm{OH}^{-}\right)$. The reaction is reversible and can take place in a batch reactor or as a continuous process in a packed column. Ion exchange resins must contain ions in their structure, be insoluble in water, and have space in their porous structure for ions to pass freely in and out of 
the solid. Synthetic resins, as well as some naturally occurring clays, can be used as the ion-exchange medium. Ion-exchange materials can be either anio$n i c$ or cationic, depending upon the composition of the particular resin. The classification of resin indicates the the type of ion removed. Ion-exchange materials or resins contain mobile active sites on their surfaces that are replaced by ions of the same charge from solution. Equal charge quantities are exchanged to ensure charge neutrality. The exchange process continues until the chemical driving forces are the same in the solution and in the pores of the solid. When this occurs, the resin must be regenerated with a highly concentrated solution of the ions that were originally on the exchange material.

The quantity of ions that can be removed by an exchange resin from solution is an important factor. This capacity is a function of a specific material and is expressed in equivalents per gram dry weight. Another property of an ionexchange material is the selectivity or relative preference for adsorbing different types of ions. Since electrostatic forces between ions and resins increase with increasing charges, ions with higher valances are preferentially adsorbed. Relative size of ions in solution also affects the selectivity of ion exchange. For a series of ions with equivalent charge, the resin prefers the ion with the smallest diameter.

Ion exchange usually takes place in a packed bed in which the wastowater is fed continuously from the top or bottom. Ions are exchanged in a zone within the bed that moves slowly in the same direction as the wastewater. Behind the zone is spent resin and ahead of the zone is fresh resin. When all the resin in the bed is spent, breakthrough occurs, and the bed must be regenerated.

This process is used for water softening, demineralization of boiler feedwater, purification of chemicals, and material recovery. It is an efficient and cost effective process, it can be automated, and it has a relatively low operating cost, not including the treatment of regeneration wastewater.

Use of ion exchange resins has several limitations. Cationic exchange resins cannot withstand temperatures greater than $250-300^{\circ} \mathrm{F}$. Anionic resins break 
down at temperatures exceeding $140^{\circ} \mathrm{F}$. Strong oxidizing agents, as well as iron, manganese, and copper, will degrade the resins in the presence of oxygen. Resins become fouled by precipitation or irreversible adsorption of suspended solids, oils, and other dissolved materials. Rapid exposure to alternating high and low electrolyte concentrations induces osmotic shock, resulting in resin fracture. For dissolved solids in concentrations in excess of 500-1000 $\mathrm{mg} / 1$, pretreatment to reduce dissolved solids to below $500 \mathrm{mg} / 1$ may be required to prevent clogging of beds.

Reverse Osmos is

Reverse osmosis (RO) is the process of reversing the normal flow of dissolved material in solution across a membrane separating a dilute from a concentrated mixture. When separated by a semi-permeable membrane, water molecules in the dilute solution will migrate through the membrane to the concentrated side because water in pure form is at a higher energy state than in a solution and tends to move to the lower energy state. In reverse osmosis, the pressure on the concentrated side of the membrane is raised above the pressure forcing the water to move from the dilute side, called osmotic pressure. Once the concentrated solution has a pressure exceeding the osmotic pressure applied to it, the water molecules in the concentrated solution will be at higher energy and will flow across the semi-permeable membrane to the dilute side, reversing the normal osmotic flow.

RO membranes can operate only within certain ranges of $\mathrm{pH}$ and temperature and will be destroyed by high concentrations of oxidizing agents. As an example, cellulose acetate membranes are limited to a $\mathrm{pH}$ range of 5 to 8 and cannot withstand a chlorine concentration of $5 \mathrm{mg} / 1$ for more than 15 minutes. A polyamide membrane is limited to a pH range of 4 to 11 and chlorine concentrations of 0.1 to $0.25 \mathrm{mg} / 1$. Both membranes will fail at operating temperatures in excess of $95^{\circ} \mathrm{F}$. Newer membranes have been developed that greatly extend the range of applicability of RO. Membranes are also limited in that solutions can be concentrated. only to the solubility of the least soluble salt in solution. Further attempted concentration will result in membrane fouling and plugging because of salt precipitation. 
RO is presently used to produce fresh water from salt or brackish water on a large commercial scale, to purify industrial chemicals and pharmaceuticals, and for material recovery. The advantage of the process is that most wastewater components can be removed in a single operation. The disadvantages of the process include maintenance problems, such as membrane fouling and degradation, a relatively high energy requirement, and a high initial cost.

\section{Evaporation}

Evaporation is the process of liberating pure water in the form of water vapor from a solution. Examples include evaporation ponds, multiple effect evaporators, multistage flash evaporators, and vapor compression evaporators.

In evaporation ponds, wastewater is discharged to the ponds and the water is evaporated by solar heating. After the water has evaporated, the remaining salt cake is disposed of. Ponds can be covered by glass or plastic covers to recover the vaporized water. The vapor condenses on the underside of the cover and is then collected for reuse.

Multiple effect evaporation is a system that incorporates a number of evaporation chambers in series. Each uses steam from the preceding stage to evaporate water at a lower pressure than that of the preceding stage. The recovery of heat from each stage of the evaporation process reduces the operating costs of this system.

In mult1stage flash evaporation, the incoming water is pressurized and heated to just below the boiling point. The water is then depressurized in stages, evaporating the water. Water vapor is then condensed by exchanging heat with the incoming feedwater.

Vapor compression evaporates and recovers water through the use of mechanical energy. In this system, the incoming water is heated to $212^{\circ} \mathrm{F}$ at atmospheric pressure. The steam formed is collected and then compressed. The superheated steam then is allowed to release its energy to the water in the evaporator, 
heating the contents. The condensate is then used to heat the incoming water to the process.

In general, evaporation systems are extremely energy intensive because of the high heat of vaporization of water. Solar processes are relatively cheap in operating costs, but the extensive land requirements of 10 to 12 square feet per gallon and the variability of solar heating limit its use. The most efficient evaporation process is vapor compression, but it requires a high capital investment. A drawback of evaporation systems is the fouling of heat exchanger surfaces by solids. The multistage flash process avoids this problem by not using an exchanger surface to evaporate water. Common methods used for the control of solids deposition are use of antiprecipitant chemicals or operation at levels not exceeding the solubility limit. Equipment has also been developed which resists fouling. The temperature difference driving force is often limited by the solubility limit of the dissolved solids.

The largest disadvantages of evaporation processes are the high energy requirements, high maintenance, and high capital costs. The advantage of this process is that dissolved solids can be effectively removed from wastewaters, and the resulting product water is exceptionally pure.

Uitrafiltration

Ultrafiltration is the use of a membrane to separate a moderately high molecular weight solute from an aqueous solution. Ultrafiltration requires solute molecules about ten times larger than solvent molecules and a negligible pressure across the membrane. Ultrafiltration membranes retain relatively large solute molecules by a sieving process in which the solvent appears to move through the membrane in viscous flow while the larger solute, particles cannot pass through.

Ultrafiltration has disadvantages in that the membrane is subject to fouling and degradation. The process has been used to concentrate solids in a sludge reactor and to recover protein and sugar products from waste streams in cheese 
and candy factories. It is still very much in the experimental stage with coal gasification wastewaters. Its primary usefulness will be in the removal of relatively large organic molecules, such as oil.

\section{Electrodialysis}

The electrodialysis process removes ions from water by using a direct current electric field to force their migration through a semipermeable membrane. The solute ions and other charged materials are the mobile molecules and cross through the membrane in contrast to reverse osmosis, where the snlvent (water) is forced through the membrane. A series of parallel mambrancs is used to separate the charged ions. The induced electric field causes the inns to $\mathrm{mi}$ grate towards oppositely charged membrane. The ions pass through the membrane into a concentrated solution of ionic impurities. Purified water is produced between every other set of membranes. This arrangement of membranes may be repeated as many as 700 times to produce ion-free water.

Electrodialysis is capable only of removing charged ionic particles from solutions. Unlike reverse osmosis, electrodialysis has little effect on uncharged dissolved particles and suspended solids. The process is somewhat energy efficient, with the energy costs directly proportional to the impurity of the feed. Membrane fouling, particularly of the anionic type, is a problem. The membranes are ion exchange resins manufactured in sheet form and therefore, like exchange resins, require pretreatment.

The concentration of the brine solution is limited by the precipitation of solids out of solution ont.n the membrane. Chemical compounds can be added to the solution to prevent the precipitation.

Electrodialysis is presently used for demineralization of brackish water, and there are pilot plants for testing wastewater treatment. The advantage of this process is that 40-50\% of the dissolved salts can be removed in a single pass. A disadvantage of the process is membrane fouling. There is limited experience in using this process for wastewater treatment. 


\subsection{EFFLUENT STANDARDS AND APPROVED INSTRUMENTAL METHODS}

Water quality is protected through the enforcement of both ambient water quality standards and effluent discharge standards. Ambient standards vary from state to state and vary for different receiving waters within states. These ambient standards depend upon current water quality and the environmental and recreational values that are designated for protection in each receiving stream, river, or lake. Effluent discharge standards, on the other hand, depend upon the type of industry and the type of process. They are formalized as New Source Performance Standards (NSPS).

\subsubsection{Effluent Standards}

The Federal Water Pollution Control Act of 1972 (Public Law 92-500) required the EPA to establish standards for effluent discharges from point sources into the navigable waters of the United States. Point sources are usually considered to be effluents from pipes or sewers rather than runoff during rainfall.

Stormwater discharges are included if the water is contaminated in a particular area (i.e., coal storage). Presently, Federal regulations for the control of water pollution are issued on an industry-wide basis. Since the coal gasification industry is just emerging, Federal regulations for that industry have not been developed. Examination of effluent standards for similar industries will assist in estimating the forecoming regulations.

Public Law 92-500 makes it illegal to discharge certain wastewaters wi thout a National Pollutant Discharge Elimination System (NPDES) Permit. The permit must stipulate that a certain minimum technology is to be used in treating the effluent. The minimum standard to be achieved by July 1, 1977 is that of Best Practicable Technology (BPT) currently available. This technology is based upon the average of the best performances of existing treatment technology in the industry category. By July 1, 1983 the treatment of point sources will be based on the Best Available Technology (BAT). BAT will not be based upon the average 
of the best performance but will be determined by the very best treatment technology to treat a specific point source. The final goal is the elimination of all discharges by July 1, 1985, commonly referred to ás zero-discharge.

In the case of coal gasification, the New Source Performance Standard (NSPS) have not been established. These standards will, for the most part, use BPT guidelines. As BAT standards become enforceable, they will replace NSPS and BPT regulations. Furthermore, when zero-discharge regulations become enforceable in 1985, the treatment plants must be upgraded to achieve this ncw performance. All of these regulation changes, coupled with the absence of any new source performance standards, have placed the effluent standards for the coal gasification industry in a state of confusion. One solution would be to bypass all interim regulations and base design upon zero-discharge constraints. This would eliminate the successive updating of designs and construction as the regulations become stricter. The other solution is to estimate effluent standards from NSPS from related industries by identifying processes similar to gasification processes and using standards applied to those processes.

Industries that are under NSPS regulations and also in some way related to coal gasification are iron and steel, petroleum refining, coal mining, and steam electric power generation. Regulations for these industries are shown in Table 4.1. Cumpartson of standards among industries is difficult herause the standards vary widely. This is due to a trend in Federal regulations that permits an industry that emits a large amount of a certain pollutant to have a more liberal standard than is applied to an industry that discharges a small amount of the same pollutant. Also industry reports effluents on a pound per pound of product or feedstock, making comparison with ppm concentrations very difficult.

Iron and steel industry processes applicable to gasification are ammonia stripping, ammonia recovery, and acid-gas removal. Regulations applied to these processes are concerned with the $\mathrm{pH}$, phenol, total suspended solids (TSS), cyanide, 0 il and grease, and ammonia discharges in the wastewater. The regulations were normalized by assuming that 0.69 pounds of coke represented 1.0 
Table 4.1 Wastewater. Effluent Regulations

\begin{tabular}{|c|c|c|c|c|c|c|c|c|}
\hline \multirow{2}{*}{$\begin{array}{l}\text { Pollutant } \\
\text { Parameter }\end{array}$} & \multicolumn{2}{|c|}{ Petroleum Refining } & \multicolumn{2}{|c|}{ Elec. Generating } & \multicolumn{2}{|c|}{ Steel/Coke } & \multicolumn{2}{|c|}{ Coal Mining } \\
\hline & $\left(1 \mathrm{~b} / 10^{3} \mathrm{bbl}\right)$ & $\left(1 \mathrm{~b} / 10^{6} 1 \mathrm{~b}\right)^{\mathrm{a}}$ & (ppm) & $\left(1 \mathrm{~b} / 10^{1} \mathrm{Ib}\right)^{\mathrm{b}}$ & $\left(1 \mathrm{~b} / 10^{3} \mathrm{lb}\right)$ & $\left(1 \mathrm{~b} / 10^{6} \underline{1 b}\right)^{c}$ & (ppm) & $\left(\underline{1 b / 10^{6}} 1 \mathrm{bb}\right)^{d}$ \\
\hline TSS & $1.20-15.4$ & $1.80-23.1$. & 30 & 15 & 0.0104 & 7.18 & 35 & 0.24 \\
\hline Phenols & $0.01-0.125$ & $0.015-0.188$ & - & - & 0.0002 & 0.138 & - & - \\
\hline $0 i 1$ and Grease & $0.44-5.8$ & $0.66-8.72$ & 15 & 7.5 & 0.0042 & 2.90 & - & - \\
\hline & -- & - & - & - & 0.0001 & 0.069 & - & - \\
\hline $\mathrm{NH}_{3}$ & $0.28-11.0$ & $0.42-16.5$ & - & - & 0.0042 & 2.9 & - & - \\
\hline & $0.008-0.10$ & $0.012-0.15$ & - & - & 0.0001 & 0.069 & - & - \\
\hline Trace Elements & & & & & & & & \\
\hline An & - & - & - & - & - & - & 2.0 & 0.138 \\
\hline $\mathrm{min}_{\mathrm{Ni}}$ & - & - & $\overline{-}$ & - & - & - & 2.0 & 0.138 \\
\hline $\mathrm{Cl}$ & - & - & 0.2 & 0.1 & - & - & 2.0 & 0.0014 \\
\hline $\mathrm{Pb}$ & - & - & - & - & - & - & - & - \\
\hline $\mathrm{F}$ & - & - & - & - & - & - & - & - \\
\hline $\mathrm{Ba}$ & - & - & - & - & - & - & - & - \\
\hline $\mathrm{Ag}$ & - & - & - & - & - & - & - & - \\
\hline Cd & - & - & - & - & - & - & - & - \\
\hline $\mathrm{Cu}$ & - & - & 1 & 0.5 & - & - & 0.5 & 0.024 \\
\hline Total Fe & - & - & 1 & 0.5 & - & - & 0.3 & 0.0021 \\
\hline Dissolved $\mathrm{Fe}$ & - & - & - & - & - & - & - & - \\
\hline $\mathrm{Hg}$ & - & - & - & - & - & - & - & - \\
\hline As & - & - & - & - & - & - & - & - \\
\hline Total Cr & 0.037 & 0.055 & - & - & - & - & - & - \\
\hline $\mathrm{Cr}^{6+}$ & 0.0025 & 0.0038 & - & - & - & - & - & - \\
\hline $\mathrm{Zn}$ & - & - & - & - & - & - & 0.2 & 0.0014 \\
\hline Se & - & - & - & - & - & - & - & - \\
\hline BOD & $1.4-18.9$ & $2.1-28.3$ & - & - & - & - & - & - \\
\hline COD & $7.1-131$ & $10.6-196$ & -0 & - & - & - & - & - \\
\hline pH & $6-9$ & & $6-9$ & & $6-9$ & & 6.9 & \\
\hline $\begin{array}{l}\text { Based on } 3 \mathrm{bb} \\
\text { Based on } 0.5\end{array}$ & $\begin{array}{l}\text { of oil per to } \\
b \text { of water-to. }\end{array}$ & $\begin{array}{l}\text { nn of coal } \\
\text { river per ib }\end{array}$ & $f$ coal & $\begin{array}{l}c \text { Base } \\
\text { d } \text { Base } \\
\text { coal }\end{array}$ & $\begin{aligned} & \text { on } 0.69 \mathrm{lb} \\
& \text { on } 37 \times 10^{6} \mathrm{~g} \\
&= 6.71 \mathrm{gal} \mathrm{p}\end{aligned}$ & $\begin{array}{l}\text { of coke per } \\
\text { al of runof } f \\
\text { er ton of co }\end{array}$ & $\begin{array}{l}\text { id of } \\
0 \times 10^{6}\end{array}$ & $\begin{array}{l}\text { coal } \\
\text { tons of }\end{array}$ \\
\hline
\end{tabular}


pound of coal feed. This is reflected in the second column of numbers in Table 4.1 under Steel/Coke.

The petroleum refining industry is similar to coal gasification in such processes as methanation, acid-gas removal, sulfur recovery, and ammonia stripping and recovery. Wastewaters from this industry have limits for $\mathrm{pH}, \mathrm{BOD}, \mathrm{COD}$, TSS, oil and grease, chromium, ammonia, phenols, and sulfide content. These standards have been normalized to a per pound of coal basis by assuming that one ton of coal is equivalent to three barrels of oil. Storage of coal is similar for gasification plants and coal mining and steam power generation. The standards are shown in Table 4.1.

The other treatment alternative is to design for the most stringent requirement, zero-discharge. Under zero-discharge constraints, no aqueous wastewater streams can leave the plant boundaries. Water will be evaporated to the atmosphere, or reused, and most pollutants will leave in solid form. It is interesting to note that potential air pollution, as a result of zero discharge constraints, may be sufficient reason to eliminate solar evaporation as a viable treatment option.

Gasification facilities must use tertiary treatment processes to clean up effluent water for reuse. This high degree of treatment is necessary for reducing alkalinity, dissolved solids, suspended solids, and hardness. These tertiary processes, unfortunately, have not demonstrated technical feasibility at commercial scale recycle conditions. In addition, their cost effectiveness is questionable at commercial scales. Certain sidestreams may be identified for specific tertiary treatment rather than treating the entire plant flow. Zerodischarge treatment facilities must be investigated thoroughly for reliability and cost effectiveness prior to incorporating them into a design.

The individual states are being given the primary responsibility for attaining and maintaining water quality standards established by the Federal government. The state programs are required to be at least as strict as the Federal regulations. States may consent to NPDES permits granted by the EPA, or they may qualify for and administer the program themselves. 
States have been required to classify their waters according to their potential quality: These classifications depend upon the use of which the state intends for the water (e.g., drinking, recreation). No discharges can be allowed that will degrade the receiving body of water below its classification. Local water quality programs can affect coal gasification plants by imposing pre-treatment standards on the discharging of waste. Pre-treatment standards become part of the NPDES permit and are imposed on a case-by-case basis.

The states have other standards for establishing water quality standards. The EPA listing of toxic water pollutants names compounds that have been identified as toxic and must not be discharged into bodies of water. The National Interim Primary Drinking Water Standards state maximum allowable concentrations of chemicals for drinking water.

The three gasification plants specifically discussed in this report are sited in the states of Illinois, Ohio, and Tennessee. The effluent standards for each state are sumarized in Table 4.2. The standards show allowable concentrations of various elements and other pollutants. For these three proposed gasification plants, these standards will be the basis for estimating the effluent requirements.

At the present time, regulations for liquid discharges from coal gasification facilities are in the developmental stage. The best available information on what the regulations could be can be obtained from regulations for similar industries. Until an official NSPS is promulgated by the EPA, regulation of wastewaters from gasification plants will be done through normal permitting procedures.

\subsubsection{Approved Instrumental Methods}

The U.S. EPA has published guidelines for approved instrumental methods for wastewater analyses47. Public Law 92-500 and the subsequent development of the National Pollution Discharge Elimination System (NPDES) allow or require instrumental methods for enforcement of the Permits Program. These approved instrumental methods are listed in Table 4.3. Table 4.4 identifies those metals that 
Table 4.2 State Wastewater Effluent Standards

Daily Maximum Concentrations [mg/l]

$\begin{array}{lccc}\text { Parameter } & \text { Illinois } & \text { Onio } & \text { Tennessee } \\ \text { Alumi num } & - & - & 250 \\ \text { Ammonia } & 3.0 & - & - \\ \text { Antimony } & - & - & 1.0 \\ \text { Arsenic } & 0.25 & 0.05 & 1.0 \\ \text { Barium } & 2.0 & 1.0 & 5.0 \\ \text { Boron } & - & - & 50.0 \\ \text { Cadmium } & 0.15 & 0.005 & 0.01 \\ \text { Chlorine (total) } & - & - & 2.0 \\ \text { Chromium (total) } & - & - & 3.0 \\ \text { Chromium (Hexavalent) } & 3.0 & 0.05 & - \\ \text { Cobalt } & - & - & 10 \\ \text { Copper } & 1.0 & - & 1.0 \\ \text { Cyanide } & 0.025 & 0.025 & 0.05 \\ \text { Dissolved Solids } & - & 500 & - \\ \text { Fluoride } & 15.0 & 1.0 & 20.0 \\ \text { Iron } & 2.0 & - & 10.0 \\ \text { Lead } & 0.1 & 0.05 & 0.1 \\ \text { Manganese } & 1.0 & - & 10.0 \\ \text { Mercury } & 0.0005 & 0.005 & 0.05 \\ \text { Nickel } & 1.0 & - & 3.0 \\ \text { Oil and Grease } & 15.0 & - & 30.0 \\ \text { Phenols } & 0.3 & - & 1.0 \\ \text { Phosphorus } & 1.0 & - & - \\ \text { Selenium } & 1.0 & 0.005 & 0.01 \\ \text { Silver } & 0.1 & 0.05 & 0.05 \\ \text { Suspended Solids } & 15 & - & 40 \\ \text { Zinc } & 1.0 & & 2.0\end{array}$


Table 4.3 Approved Instrumental Methods*

FR

No.

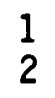

3

10

13

14

16

17.

18

19

20

21

22

23

24-87

88

89

90

91

93

94

95

96

97

98

99-103

104-108

109

110

111

113

115
Parameter

Acidity

Alkalinity

Ammonia

Biochemical Oxygen Demand

Chl oride

Chlorinated Organic Compounds

Color (except pesticides)

Cyanide

Cyanide Amenable to Chlorination

Dissolved Oxygen

Fluoride

Hardness

Hydrogen Ion ( $\mathrm{pH})$

Kjel dahl Nitrogen

Metals

Nitrate

Nitrate

0 il and Grease

Organic Carbon

Orthophosphate

Pentachl orophenol

Pesticides

Phenols

Phosphorus (elemental)

Phosphorus (total)

Radiological

Residue

Specific Conductance

Sulfate

Sulfide

Surfactants

Turbidity
Instrument

$\mathrm{pH}$ meter

$\mathrm{pH}$ meter

Automated Colorimetric Analyses Ion Select ive Electrode Meter Automated Colorimetric Analyses Ion Selective Electrode Meter Automated Colorimetric Analyses

Gas chromatography

Spectrophotometer

Spectrophotometer

Spectrophotometer

Ion Selective Electrode Meter

Ion Selective Electrode Meter

Spectrophotometer

Automated Colorimetric Analyses

Automated Colorimetric Analyses

$\mathrm{pH}$ Meter

Automated Colorimetric Analyses

Atomic Absorption Spectrophotometer

Automated Colorimetric Analyses

Automated Colorimetric Analyses

Balance

TOC Analyzer

Automated Colorimetric Analyses

Gas Chromatography

Gas Chromatography

Spectrophotometer

Gas Chromatography

Spectrophotometer

Automated Colorimetric Analyses

Proportional or Scintillation Counter

Balance

Conduct ivity Meter

Automated Colorimetric Analyses

Photometer

Spectrophotometer

Nephel ometer

* Reference 47 
Table 4.4 Metal Analyses by Atomic Absorption

$\begin{array}{ll}\text { Aluminum } & \text { Molybdenum } \\ \text { Antimony } & \text { Nickel } \\ \text { Arsenic } & \text { Osmium } \\ \text { Barium } & \text { Palladium } \\ \text { Beryllium } & \text { Platinum } \\ \text { Cadmium } & \text { Potassium } \\ \text { Calcium } & \text { Rhodium } \\ \text { Cliruillull } & \text { Ruthenium } \\ \text { Cobalt } & \text { Selenium } \\ \text { Copper } & \text { Silver } \\ \text { Gold } & \text { Sodium } \\ \text { Iridium } & \text { Thallium } \\ \text { Iron } & \text { Tin } \\ \text { Lead } & \text { Titanium } \\ \text { Magnesium } & \text { Vanadium } \\ \text { Manganese } & \text { Zinc }\end{array}$

Mercury (flameless AA) 
can be measured by atomic absorption. Methods that are also appropriate for measurements in the field are separately listed in Table 4.5.

The approved instrumental methods are appropriate for measuring the iower contaminant concentration associated with wastewaters treated for discharge. They are also applicable for measurements of the raw or intermediate wastewater undergoing processing in a wastewater treatment system. 
Table 4.5 Approved Field Instrumental Methods

\begin{tabular}{|c|c|}
\hline $\begin{array}{l}\text { FR } \\
\text { No. }\end{array}$ & Parameter \\
\hline 1 & Acidity \\
\hline 2 & Alkalinity \\
\hline 3 & Ammonia \\
\hline 19 & Dissolved oxygen \\
\hline 20 & Fluưride \\
\hline 22 & Hydrogen ion $(\mathrm{pH})$ \\
\hline 109 & $\begin{array}{l}\text { Specific } \\
\text { conduct ance }\end{array}$ \\
\hline 115 & Turbidity \\
\hline
\end{tabular}

Instrument

$\mathrm{pH}$ Meter

$\mathrm{pH}$ Meter

Ion Selective

Electrode Meter

Ion Selective

Electrode Meter

Ion Selective

Electrode Meter

$\mathrm{pH}$ Meter

Conductivity Meter

Nephel ometer 
SECTION 5 - GASIFICATION DEMONSTRATION PLANT WASTEWATER TREATMENT

SYSTEM ANALYSES

\subsection{INTRODUCTION}

This section analyses the wastewater treatment systems that have been designed, for an industrial low Btu fuel gas demonstration plant and two high Btu pipeline gas demonstration plants, which were proposed by the U.S. DOE. The fuel gas plant of the Memphis Light, Gas, and Water Division (MLGWD), located in Shelby County, Tennessee, uses the U-Gas process. The CONOCO pipeline gas demonstration plant, located in Noble County, Ohio, uses the Slagging Lurgi (BG) process. The Illinois Coal Gasification Group (ICGG) is designing a high Btu gasification facility for a site in Perry County, Illinois, using the COGAS process.

This section identifies and characterizes the internal plant wastewater streams from all individual sources for each plant and discusses the wastewater treatment systems designed for each plant. Treatment system designs are analyzed; any information gaps that hinder these analyses are identified. Particular attention is given to individual wastewater treatment unit reliability. Unit reliability is critical to total treatment system reliability.

\subsection{ICGG PIPELINE GAS DEMONSTRATION PLANT}

The ICGG demonstration plant is designed for a site in Perry County, Illinois, to convert approximately 2220 tons of coal per day into high Btu, pipeline quality gas and liquid products. Gasification uses the COGAS process. The design has incorporated the use of Illinois \#5 or \#6 Bituminous, Pittsburgh \#8 Bituminous, or Western Sub-bituminous coal.

The wastewater treatment system is designed for zero discharge because the plant site is too far from a suitable receiving hody of water. The wastewater treatment system must be capable of treating wastewaters to a quality suitable for plant reuse. 
In the plant, oil-contaminated runoff, process wastewaters and sanitary wastewaters are processed by a pure oxygen-activated sludge plant and recycled as makeup to the cooling tower and boiler feedwater systems. Flows identified as being high in TDS are treated in multi-effect evaporators and recycled as boiler feedwater makeup. The treatment of quench condensates includes stripping for ammonia removal. The ammonia stripper bottoms has high phenolic concentrations. The proposed wastewater treatment system is shown in Figure 5.1.

\subsubsection{Wastewater Sources and Characteristics}

The wastewaters generated by the plant can be divided into the following sections: contaminated stormwater run of $f$, clean stormwater runoff, high dissolved solids wastewaters, sanitary sewage, process sewer, and ammonia stripper bottoms.

Cont aminated Stormwater Runoff

The contaminated stormwater flow consists of runoff from the dead coal pile, the oil storage area, and the contaminated storm sewer. Data from the design engineer on the characteristics of this flow are not available. In the absence of such information, assumptions have been made to approximate the wastewater characteristics. Typically, a dead coal pile is treated with sune type of agent to seal the pile from rainfall leaching. If no such treatment is performed on the dead pile, then a stormwater runoff similar to that from live coal storage can be expected. Runoff from a treated pile will be near neutral pH and contain few dissolved solids if the rain has been is prevented from contacting the coal. Some suspended solids and some of the crusting agents can be expected to contaminate this runoff, however.

Stormwater runoff from the oil storage area and the process area is expecled to be contaminated by oils and suspended solids. There are no data on the composition of this flow. It is estimated that oils will have concentrations in the $1000-5000 \mathrm{mg} / 1$ range, suspended solids in the $400-800 \mathrm{mg} / 1 \mathrm{range}$, and dissolved solids less than $500 \mathrm{mg} / 1$. The dilution and temporary storage of this 


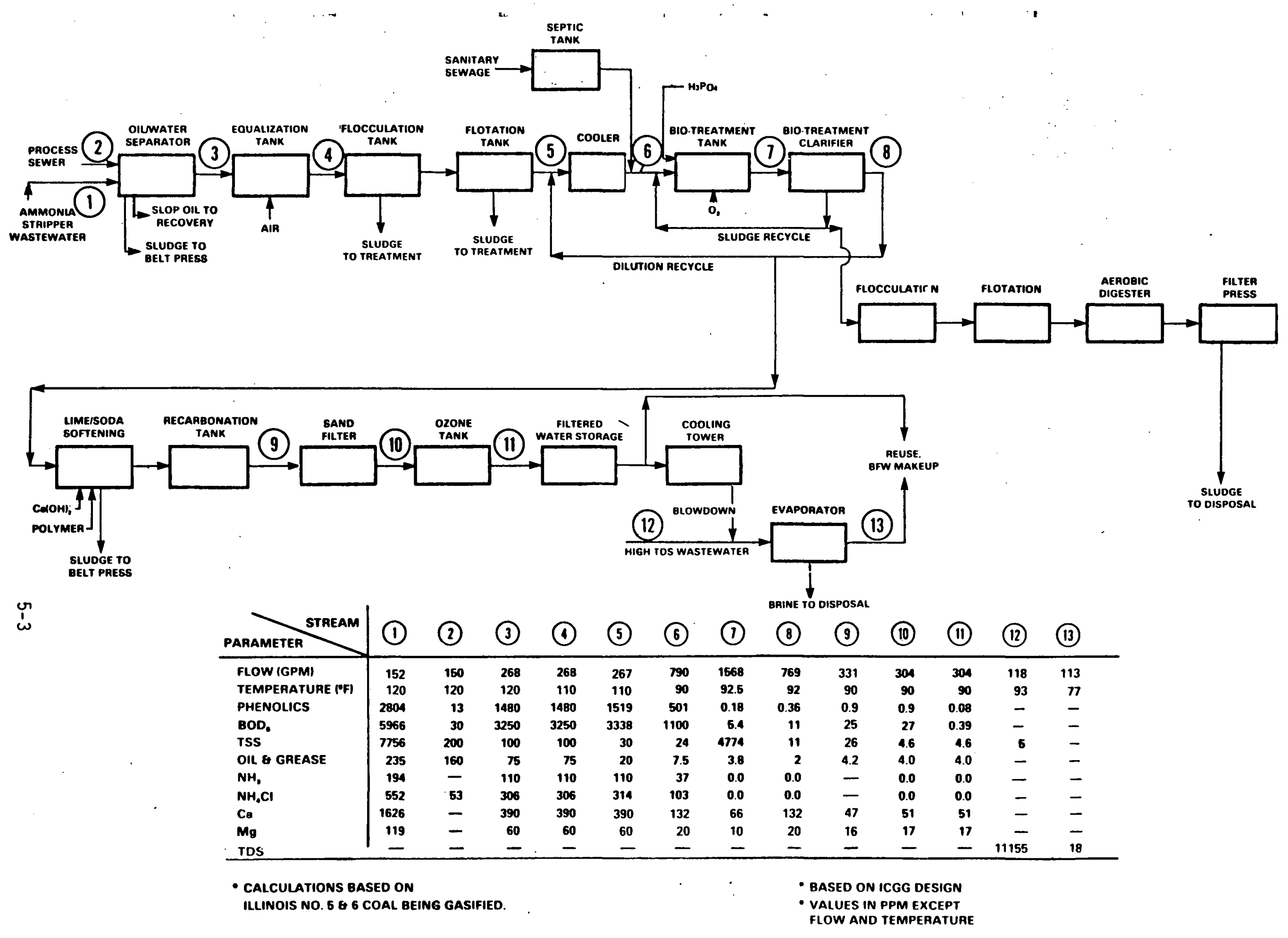

Figure 5.1 ICGG Wastewater Treatment Plant Flow Diagram 
intermittent flow in the stormwater holding basin will minimize surge loading of the wastewater treatment system.

\section{Clean Stormwater Runoff}

\section{$F$}

Collected stormwater from uncontaminated areas is impounded prior to being pumped to the raw water reservoir. If the stormwater is contaminated or not suitable for raw water feed, it is diverted to the process wastewater treatment plant. Live coal pile runoff is collected separately and pumped to the high TDS wastewater evaporators for treatment.

High Dissolved Solids Wastewaters

Waters that contain high levels of dissolved solids and low levels of organic impurities are processed by evaporators prior to treatment for use as boiler makeup. These wastewaters include cooling tower blowdown, lime reactor regenerant, deionizer backwash water, live coal pile runoff, and cation exchanger regenerant. The flow to the evaporators is maintained steady using an inorganic waste hold tank to avoid fluctuations during backwash cycles and rainfall events. Dissolved solids concentration in this combined wastewater is estimated to be $12,000 \mathrm{mg} / 1$. This value is reasonable for this type of wastewater.

\section{Sanitary Sewage}

Sewage collected within the plant is sent to a septic tank for primary treatment. The effluent from the septic tank contains fairly high concentrations of BOD $(300 \mathrm{mg} / 1)$ and suspended solids $(500 \mathrm{mg} / \mathrm{l})$. It is assumed that the $100 \mathrm{mg} / 1$ of oils and grease reported by the designer originate from a kitchen facility. This wastewater will also be expected to have $500-900 \mathrm{mg} / 1$ of TDS and $40-90 \mathrm{mg} / 1$ of nitrogen. These two constituents are not included in the mass balance. Because of the small flow, this omission will not have a major impact on wastewater treatability. 
Process Sewer

The process sewer collects wastewaters from plant areas and conveys it to the wastewater treatment area. Contaminated stormwater is also conveyed to the main wastewater treatment area. Wastewaters high in dissolved solids are collected and treated separately in an evaporation system. The process sewer has been estimated to contain about $13 \mathrm{mg} / 1$ of phenols, $30 \mathrm{mg} / 1$ of BOD, $200 \mathrm{mg} / 1 \mathrm{TSS}$, $160 \mathrm{mg} / 1$ oil and grease, and $53 \mathrm{mg} / 1$ of $\mathrm{NH}_{4} \mathrm{Cl}$. These concentrations appear reasonable at this time but may change as the plant becomes operational.

Ammonia Stripper Bottoms

A major process wastewater is the ammonia stripper bottoms from the ammonia recovery area. This wastewater has a high phenol and suspended solids concentrations and is high in BOD.

\subsubsection{Wastewater Treatment System Analysis}

The following sections investigate the treatment systems for the wastewaters described above.

Contaminated Stormwater Runoff

Contaminated runoff is collected and pumped to an oil/water separator for treatment. If the assumed influent concentrations are correct, this type of treatment is sufficient to reduce oils and suspended solids to levels that will not impede further treatment. The separator removes about $75 \%$ of the $0 i 1,25 \%$ of suspended solids, and $20 \%$ of BOD and COD, resulting in an effluent with 250-1250 $\mathrm{mg} / 1$ oil and 300-600 $\mathrm{mg} / 1$ of suspended solids. Flow is then stored for a period of time in the contaminated stormwater basin before being pumped to the front of the process wastewater treatment plant. Provisions are included for pH adjustment of the water before storage in the basin, if necessary. Further treatment of the wastewater by the process wastewater plant should remove all remaining contaminants to levels sufficient for reuse of the water. 
It is not clear at this time what parameters would be used to determine the suitability of the runoff as raw water feed. Presumably, critical factors are be TDS, suspended solids, and organic pollutants. The selection criteria should be identified.

\section{Process Sewer}

The process sewer wastewater, which is weak, is mixed with the ammonia stripper wastewater before treatment to dilute the stronger wastewater.

\section{Sanft.ary Sewage}

Sanitary sewage is treated in a septic tank to remove suspended solids and BOD and reduce the volume of solids through digestion. The supernatant from the septic tank is pumped to the aeration basin of the process wastewater treatment plant. Because this flow is only $3 \%$ of the plant flow, the septic tank effluent is not expected to influence the plant operation significantly.

\section{Process Wastewaters}

Process wastewaters are treated by using various physical-clitulcal processes and by biological oxidation, as shown in Figure 5.1 .

Process wastewaters are first treated in a crossflow corrugated plate oil separator for coarse removal of floating oils and settleable solids. The process sewer flow is added to the stripped bottom flows from the ammonia stripper unit prior to the separator. Free floating ofl is collected and recovered in the separator. Settleable solids are pumped to a filter press and then sent to a landfill.

The oil separator is designed to remove $60 \%$ of the $0 i 1$ and grease, $97 \%$ of the suspended solids, and $52 \%$ of the Ca+t. Removal of calcium is most likely due to the excess lime added to the ammonia stripper water. This lime forms insoluble hydroxides with calcium and is then precipitated out of solution in the 
separator. The above explanation for calcium removal is an assumption because $\mathrm{pH}$ information is lacking. The estimated removal of solids at this stage of treatment seems high. Typical values should be in the $80 \%$ range. Zero removal of BOD in this unit does not seem consistent with solids removal. Some BOD should be removed unless solids are totally inert. The area cannot be examined further without test results on the solids at this stage of treatment. 0 il and grease removals appear consistent with the literature.

Separator effluent is pumped to an equalization tank to dampen hydraulic and pollutant surges to the treatment system. The tank is sized for a 2-day detention time and provides mixing of wastewater and suspension of solids by bubbling air through the contents. If the hydraulic or contaminant shock is too great, the wastewater can be diverted to an emergency storage basin unt il treatment can be performed. The methods used to determine that a contaminant shock is too great before operational damage is done to the system (i.e. biological failure) are unknown.

The wastewater from the equalization tank is then mixed with a polymer and treated in a flocculation/flotation system for removal of solids and both separable and emulsified oils. Mixing in the flocculation tank and gas for flotation is provided by electrolytically hydrolyzing the water at the bottom of both tanks. Removals for this process are $70 \%$ for suspended solids and $73 \%$ for $0 i l$ and grease. These removals are consistent with the literature for conventional air flotation processes. It is not known what removals can be expected from an electrolysis process.

Effluent from the flotation unit is joined by a recycle flow from the aeration clarifier. The purpose of the recycle stream is to dilute the phenols in the aeration tank feed to $500 \mathrm{mg} / \mathrm{l}$. The combined stream is then cooled, if necessary, to $90^{\circ} \mathrm{F}$. This temperature has been determined to be the optimum oxidation temperature. The cooled, diluted wastewater is then $\mathrm{pH}$ adjusted to 7.0 with phosphoric acid, which also serves as a nutrient for biological oxidation. Added nitrogen may also be needed as a nutrient. 
The stream is then treated by a pure oxygen activated sludge system. The oxygen plant provides a concentrated oxygen source to the biomass and allows the process to withstand higher organic shock loadings than a conventional air system does. The expected $100 \%$ removal of ammonia during the pure oxygen activated sludge process is unreasonably high. Actual removals will be less (even if nitrification takes place). The biomass is settled from the wastewater in a clarifier. A portion of the sludge produced in the clarifier is recycled to the aeration tanks to maintain the desired mixed liquor concentration of organisms in the aeration tank. The remainder of the sludge is thickened by a flotation unit and is then processed in an aerobic digester. The aerobic digester cdll supply biomass to start the process again in the event of an aeration tank failure.

From the biotreatment clarifier, the wastewater is pumped to the lime/soda softening system at a controlled rate. This system reduces calcium ion and magnesium ion concentrations to those found in the raw water. Lime/soda softening processes also remove some organics from the wastewater. If there is not sufficient alkalinity in the wastewater to remove the non-carbonate hardness, soda ash $\left(\mathrm{Na}_{2} \mathrm{CO}_{3}\right)$ will be added to precipitate the remaining calcium. Excess lime $\left(\mathrm{Ca}(\mathrm{OH})_{2}\right)$ may be necessary to remove magnesium. If this is the case, Cat+ ions from the excess lime will be removed by bubbling $\mathrm{CO}_{2}$ into the water. The $\mathrm{CaCO}_{3}$ precipitate formed will be flocculated and clarified. Within the recarbonation system, it is noted that there is no control over the $\mathrm{pH}$ of the wastewater during recarbonation. It is strongly suggested that the $\mathrm{pH}$ be maintained above 9.5 if excess $\mathrm{Ca+}+$ ions are to be removed using recarbonation, or the insoluble $\mathrm{CaCO}_{3}$ precipitate will begin to go back into solution, making recovery impossible. A modification to the recarbonation system that would reduce the capital cost is the use of $\mathrm{CO}_{2}$ in the flocculation tank as a mixing medium. Elimination of a separate recarbnnation drum and bubbling $\mathrm{CO}_{2}$ into the flocculation tank would keep the wastewater mixed as the $\mathrm{CO}_{2}$ adds carbonate to the wastewater. The combination of these two processes could result in a more efficient process. 
The effluent from the recarbonation facility is then filtered by a gravity sand filter to further remove solids generated in the biological treatment plant. The filtered water is then treated in an ozonation tank, where refractory organics are reduced to simpler compounds and further degraded. The ozone contact tank effluent is then used as make-up to the cooling tower and the boiler water treatment system.

\section{Data Gaps}

ICCG's proposed treatment process has been analyzed against the gasification data base generated for this report and general knowledge of industrial treatment systems. From that analysis, the following data gaps and comments have been identified.

1) The composition of the stripper wastewater is a data gap because liquid effluent characteristics from the unified COGAS process are not available.

2) Data on the alkalinity, PH, TDS, and TOC of the wastewater should be added to the process flow diagrams to give a better indication of unit treatment efficiencies.

3) Adequate data do not exist on the process of producing bubbles for flocculation and flotation by electrolysis of water. The process seems to be very energy intensive, and the advantages of this system over other more conventional flotation systems is not clear.

4) The need for dilution of the flow into the aeration tanks to maintain phenol concentrations below $500 \mathrm{mg} / 1$ does not seem to be substantiated in the data base. Phenols in excess of $1500 \mathrm{mg} / 1$ have been successfully treated using biological oxidation. Unless some other factor is influencing the requirement for dilution, its need is questionable. 
5) The selection of oxygen instead of air for the biological oxidation system is a data gap. Current literature provides no data on its use with gasification wastewaters. It is recognized, however, that oxygen processes should be successful wherever air processes are successful.

6) The ozonation system used to degrade refractory organics does not prevent the release to the atmosphere of simpler organics during cooling tower operation. In addition, the effectiveness of ozonation in degrading the coal-origin refractory organics is not fully proven. On the other hand, the cost of the designed ozonation system could be very high comparing with alternatives such as carbon adsorption.

\subsubsection{Wastewater Treatment System Risk Analysis}

Overall, the wastewater treatment system has been rated as a medium risk because treatment of wastewaters from an integrated COGAS facility has not been accomplished. Some treatment units used have not even been used in treatability studies for coal gasification wastewaters, and their performances are questionable. Other processes are completely novel in their design, and in a facility where reliability is most important, these unproven processes may create more problems than they propose to solve.

Contaminated Stormwater Run of $f$

The risk assigned this treatment system is low. Considerable experience from related facilities is available to evaluate this area. The composition of the runoff could be derived from data for runoff from other industrial facilities that use coal. The treatment processes are conventional and have been proven.

Wastewaters High in Dissolved Solids

Treatment of these waste streams by evaporation is considered to be a low risk. Evaporation is a commercially proven process; however, no commercial experience exists with wastewater from a gasification facility, and there may be problems 
with scaling and foaming. The effluent from an evaporator is expected to be suitable for reuse in the boiler or cooling tower systems. The brine generated by evaporation may contain materials at hazardous concentrations. The disposal of the brine, if this is the case, will be under very strict Resource Conservation Recovery Act regulations.

\section{Clean Area Stormwater Runoff}

Although data from this area are lacking, clean area stormwater treatment shall be considered to be a low risk. Only minimal treatment of this flow stream should be required to bring it up to the quality of the raw water being brought into the plant.

\section{Process Sewer}

This area is assigned a low risk. The characteristics of this flow stream are: unknown; however, it is expected that the treatment system used will be able to areduce the pollutants to acceptable levels. The only question in this area is that various materials in toxic concentrations must be prevented from entering the sewer. Any of these substances might upset the biological reactor.

\section{Sanitary Sewage}

This area is a negligible risk. The treatment of sewage via sequential septic tank and aerobic biological processes should pose no operational problems.

Process Wastewater (Condensate and Quench Wastewaters)

The degree of risk in this area is considered to be medium. Composition of the flows into the treatment system have not been substantiated in the data base.

The pure oxygen system has seldom been used to in treat gasification wastewaters. This treatment train has serious data gaps, both on the unit operation level and the entire system level. 
To fill these data gaps, tests must be run to obtain information on the liquid effluents from the COGAS process. The degree of risk can be reduced even further by conducting treatability tests at the same location. To reduce the risk of the electrolytic generation of fine bubbles for flotation and flocculation, a side-by-side comparison should be run between this type and conventional dissolved air flotation units. The comparison should include removal efficiencies, power consumption, operability, maintainability, and reliability. If electrolytic flotation units are more advantageous, then the risk of this unit will be reduced to low. Treatability studies are required to determine the operational constraints on the use of pure oxygen biological treatment of COGAS wastewaters.

The final test to reduce the risk of this system is to connect all these treatment processes together and perform treatability tests. Until some of the interactions between the processes proposed in the treatment system are known, the risk cannot be reduced.

\subsection{CONOCO PIPELINE GAS DEMONSTRATION PLANT}

The CONOCO plant is designed to produce 19 million scf/day of $960 \mathrm{Btu} / \mathrm{scf}$ pipeline quality gas using the Slagging Lurgi Process at a site in Noble County, Ohto. The facility is designed to consume 1,396 tons per day of Ohio \#9 coal. The plant recycles all wastewaters back to the process, releasing no liquid effluents from the plant boundaries.

The wastewaters sources, characteristics, and treatment from the plant are described below.

\subsubsection{Wastewater Sources and Characteristics}

The major wastewater sources requiring treatment are clean area storm sewers, oily water sewers, sanitary sewers, coal preparation area runoff, slag quench water, and process wastewater. 


\section{Clean Area Storm Sewers}

Clean area storm sewers collect storm water runoff from process areas that do not have significant quantities of oils and other contaminants in their runoff. This water is low in BOD $(20 \mathrm{mg} / 1)$ and TSS $(50 \mathrm{mg} / 1)$ but can be high in TDS (e.g., $500 \mathrm{mg} / \mathrm{l}$ ), particularly during initial rainfall periods.

\section{Oily Water Sewer}

The oily water sewer collects vessel drains, seal-water drainage, laboratory drains, and equipment drains from areas about the plant. The wastewater in the sewer is very high in oil content $(2000 \mathrm{mg} / 1)$. For this report, these estimated quantities can be assumed to be reasonable, as no background data are currently available on characteristics for these types of wastewaters.

\section{Sanitary Sewer}

Sewage generated by personnel at the plant site is collected and treated by a separate unit.

\section{Coal Preparation Area Runoff}

The coal used to produce synthetic natural gas at this plant will be held in silos. Consequently, there will be no run off from coal storage. Coal preparation area runoff will have contaminants similar to normal coal storage runoff, but at significantly reduced amounts.

\section{Slag Quench Water}

Molten slag drops from the gasifier into a quench vessel and then into the slag lock hopper. From the slag hopper, the slag slurry is sent to a slag receiving tank before being pumped to hydrobins. Here the slag settles out prior to disposal. Effluent from the hydrobins is sent to a clarifier for further removal of solids. Clarifier overflow is pumped to the ammonia removal area. 


\section{Process Wastewater}

The major portion of the process wastewater is gasifier quench water that has undergone pretreatment for removal of tars, oils, phenol, and ammonia. Other flows are added to the process flow stream, such as oily water sewer discharges and some stormwater flows. The combined process flow stream is characterized by high levels of dissolved solids, COD and BOD. Other characteristics of the equalization basin influent are shown in Table 5.1.

Table 5.1 Estimated Influent Concentrations to Equalization Tank

$\begin{array}{cr}\text { Parameter } & \frac{\mathrm{mg} / \mathrm{l}}{\mathrm{COD}} \\ \text { BOD } & 1023 \\ \text { TOC } & 625 \\ \text { TSS } & 521 \\ \text { TDS } & 153 \\ \mathrm{NH}_{3} & 1964 \\ \text { Phenol } & 15 \\ \text { Uil } & 392 \\ \text { Thiocyanate } & 350 \\ \text { Cyanide } & 55 \\ \end{array}$

These wastewater characteristics are typical for a Lurgi gasifier wastewater stream that has undergone phenol and ammonia recovery processes. Available data for activated sludge treatment of gasification wastewaters show that most impurities are bel ow the biological inhibitory level. Ammonia may have to be added to supply the required nitrogen for the activated sludge process; it would be more cost-effective to decrease the efficioncy of the upstream ammionia stripper.

The blowdowns from the cooling tower and the slag quench are used as makeup for the slag quench and handling area. To prevent an unacceptable buildup of dissolved solids, a blowdown stream is sent to ammonia recovery for treatment. 
Data on wastewater characteristics from this area are a data gap. Depending upon the composition of the flow from the gasifier, treatment of the blowdown may be necessary. If there are few organics present, treatment with carbon adsorption and evaporation or reverse osmosis may be satisfactory if a suitable disposal facility is available for the reject.

\subsubsection{Wastewater Treatment System Analysis}

The following sections investigate the proposed treatment systems. Special attention is given to the reliability of the system and the treatment efficiencies for the various wastewaters generated by the plant.

\section{Clean Area Storm Sewer}

The storm sewer serving the clean areas discharges into a holding basin. In the basin, a floating skimmer collects any oils that float to the surface and pumps them to the slop oil storage tanks for recovery. Stormwater is pumped to the treated wastewater holding tank for reuse. Stormwater can be pumped through the process water treatment plant if it is unsuitable for reuse. This condition could occur at the beginning of a rainfall when the first flush of the sewer system produces a large amount of grit and suspended solids. These initial contaminants should be removed by recycling the flow to the process water treatment plant. An inlet diverter should be considered to divert the clean stormwater runoff that is collected after initial washdown.

The treatment system involves oil removal and possible grit and solids removal only. If the system cannot.handle the stormwater, it is pumped to the emergency holding basin and treated when the treatment plant can handle it. This stormwater is projected to contain as high as $500 \mathrm{mg} / 1$ of TDS. The blending of this flow with the effluent from the evaporator will raise the TDS level in the recycle flow from $10 \mathrm{mg} / 1$ to $80 \mathrm{mg} / 1$. It is assumed that the conditions under which the cooling tower is operated make the return of $80 \mathrm{mg} / 1$ TDS water as makeup more cost effective than increasing the evaporator capacity by $20 \%$, which would be necessary to treat the stormwater flow. 
0ily water Sewer

Waters discharged into the oily water sewer are treated in an API separator for removal of oil and suspended solids. 0 il that is removed is sent to the slop oil tank for separation and recovery. Solids removed by the separator are dewatered by a belt press and disposed off-site. The effluent flows to the equalization basin and then to the wastewater treatment plant.

At the estimated influent concentrations, the separator should remove the oil by about $75 \%$ (to $50 \mathrm{mg} / \mathrm{l}$ ), the total suspended solids by $80 \%$ (to $375 \mathrm{mg} / 1$ ), $B O D$ by $10 \%$ (to $50 \mathrm{mg} / 1$ ), and $\operatorname{COD}$ by $20 \%$ (to $230 \mathrm{mg} / 1$ ). These estimated effluent concentrations should be typical for this unit and will be suitable for feed into the wastewater treatment plant. Data have not been provided by the design engineer on the effluent conditions from the separator, so these estimates are only assumed to be representative.

Because the API Separator is typically very reliable, it is not expected to cause any major problems. The system may experience decreased removal efficiencies during periods of surges in the sewer that raise the overflow rate. If these surges result in undesirable operating conditions, it will be necessary to add an equalization basin ahead of the unit to dampen surges and provide a constant flow into the separator.

\section{Sanitary Sewer}

Sanitary sewage will be collected and treated in an extended aeration package plant. This type of treatment is suitable for this wastewater; the process has been proven to be relitable.

\section{Coal Preparation Area Runoff}

Because sized feedstocks will be stored in silos, the runoff from this area should not be as contaminated as runoff from a facility that uses open coal storage and handling. 
Leaching tests performed by CONOCO on slag from the Westfield Development Center showed the leachate to be high in ammonia and dissolved solids. The metals and compounds found in the leachate were in concentrations treatable by evaporation, reverse osmosis, or lime/soda softening. The presence of ammonia at a concentration of $1100 \mathrm{mg} / 1$, however, necessitates removal prior to reuse. The blowdown from this area is sent to the ammonia recovery area and given subsequent treatment along with the process wastewater. This treatment reduces contaminants to acceptable levels.

\section{Process Wastewaters}

A flow diagram of the treatment process is shown in Figure 5.2. The removal of the various contaminants is estimated for each unit process.

The gasifier quench condensate is first subjected to tar/oil separation. Here, coarse removal of tars and oils takes place. This wastewater is then sent to the phenol recovery area. Use of a solvent extraction process reduces monophenols by $99.6 \%$ to $33 \mathrm{mg} / 1$ and mult $i$-phenols by $60 \%$ to $1000 \mathrm{mg} / \mathrm{l}$. These removals are typical of these processes. The effluent is then treated in the ammonia recovery section, where free ammonia is completely removed and $97 \%$ of the fixed ammonia is removed. These removals are also consistent with the literature.

All miscellaneous drains from the plant are conveyed to treatment via the oily water sewer. The sewer discharges into an API separator for removal of separable $0 i l$ and solids. The effluent from the separator empties into an equalization basin that also receives all other plant flows, such as ammonia recovery effluent, landfill leachate, and clean area storm runoff (if contaminated). The equalization basin has sufficient volume for 3-day detention and will dampen hydraulic and contaminant surges. Air is bubbled into the wastewater to keep solids in suspension and to keep the contents well mixed. Provisions for $\mathrm{pH}$ control using sulfuric acid and caustic are provided. 


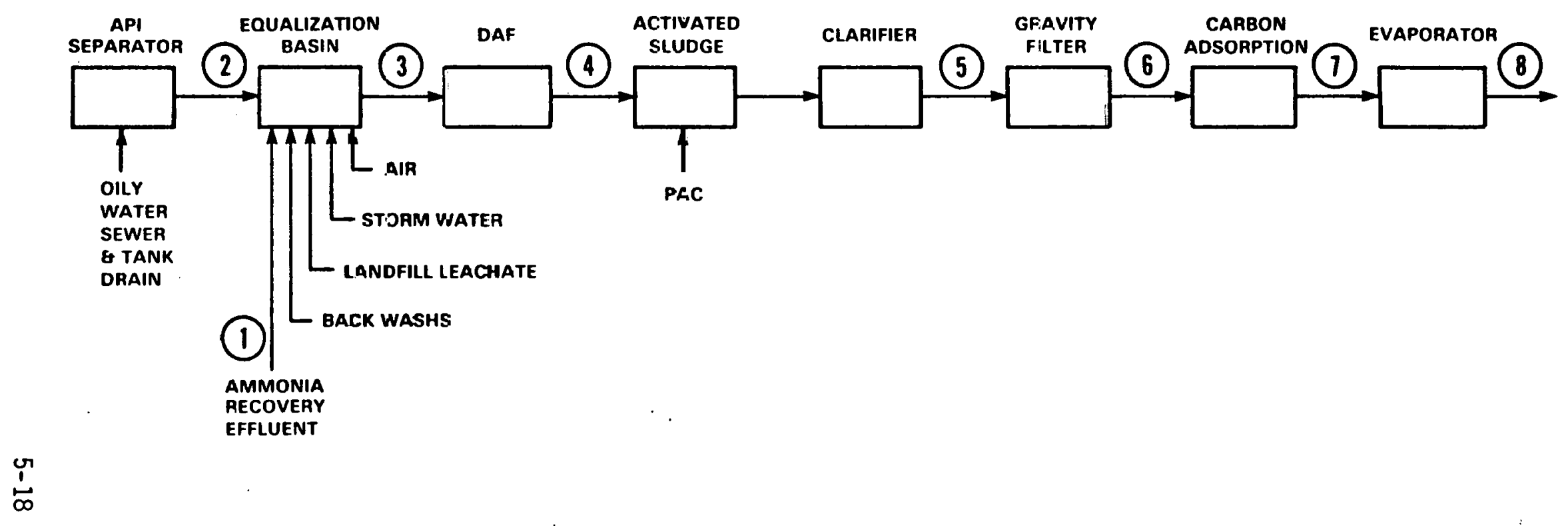

\begin{tabular}{|c|c|c|c|c|c|c|c|c|}
\hline PHENOLICS & 610 & - & 391 & 391 & 4.0 & 4.0 & 0.04 & 0.0 \\
\hline BODs & 950 & 40 & 624 & 437 & 66 & 66 & 13 & 0.0 \\
\hline TSS & 105 & 205 & 115 & 35 & 25 & 5 & 3 & 0.0 \\
\hline TDS & 2820 & 245 & 2820 & 2920 & 2820 & 3115 & 4390 & 10 \\
\hline COD & 1520 & 165 & 1029 & 720 & 220 & 220 & 44 & 0.0 \\
\hline $\mathrm{NH}_{3}$ & 23 & - & 15 & 15 & 4 & 4 & 3 & 0.0 \\
\hline OIL & 60 & 80 & 132 & $\mathbf{2 6}$ & 8 & 2 & 0.0 & 0.0 \\
\hline TOC & 775 & 80 & 521 & 417 & 100 & 100 & 20 & 0.0 \\
\hline
\end{tabular}

-all VAMUES ARE IN PRM

Figure 5.2 CONOCO Wastewater Treatment System Flow Diagram

$\because: 1+1 \quad+31$


This equalization basin is needed to prevent wide variations in contaminant concentrations from upsetting the biological unit. The equalization tank effluent is pumped to a dissolved air flotation (DAF) unit for removal of oils and suspended solids. Removal efficiencies are estimated to be $30 \%$ for $B O D$ and $C O D$, $70 \%$ for suspended solids, and $80 \%$ for oil. The effluent should not contain any oil droplets greater than 60 microns. With the equalization basin upstream of the DAF, process upsets caused by concentration fluctuations should be minimized. It is expected, therefore, that the DAF unit will have stable operation.

The DAF effluent is pumped to the activated sludge basin for removal of biodegradable organics. The process uses air as the oxygen source and operates in the extended aeration mode. With extended aeration, the plant will decrease its sludge production and increase the overall efficiency of the process relative to conventional activated sludge operation. Powdered activated carbon (PAC) can be added to the aeration tank, thereby increasing the process tolerance to toxic substances and to wide variations in concentrations.

Nutrient in the form of phosphoric acid is also added to the aeration basin. The biological solids and the PAC, if any, are settled from the wastewater in a clarifier. From the clarifier, the settled sludge and $P A C$ are recycled to the aeration tank to maintain optimum conditions for biological growth. A portion of the recycle flow is wasted and sent to aerobic digesters for volume reduction. The waste flow is necessary to prevent a buildup in solids within the process. The digester also provides a storage of biomass active in case of an upset to the biological reactor.

Removal efficiencies were not supplied by the design engineer. They are estimated, without PAC addition, to be $99 \%$ for phenol, $85 \%$ for BOD, $75 \%$ for ammonia and TOC, $70 \%$ for COD and 0.1 , and $55 \%$ for suspended solids.

Polymer is added to the clarifier overflow to reduce suspended solids leaving the gravity filters to low levels. Estimated removal efficiencies are $75 \%$ for suspended solids and oil. The filtrate is treated in a two-stage activated carbon unit. The 40-minute residence time of each reactor ensures removal of most non-biodegradable organics. 
Dissolved solids are removed by the use of a vapor recompression evaporator. The condensate obtained from this unit is free of all impurities, except for small concentrations of dissolved solids. This water is recycled back to the cooling tower as makeup water. Since this plant is designed to produce high quality effluent, it would seem more cost effective to use the evaporator condensate for the most stringent requirements, e.g. boiler feedwater. Its use as cooling tower makeup does not justify the use of evaporation. The concentrated brine is sent to the sulfur recovery area, where it is spray dried, and then landfilled.

Data Gaps

CONOCO's proposed treatment processes have been compared to the gasification data base generated for this report and general knowledge of industrial treatment processes. The resulting data deficiencies in the CONOCO design that prevent the complete assessment of these treatment systems are given below.

1) The composition of the landfill leachate is a data gap. If the leachate is principally inorganics, direct treatment hy evaporation will be applicable. The presence of organics will require treatment in a carbon adsorption unit beforc evaporation. It is nut known why the leachate must be treated by the entire treatment train.

2) The use of carbon adsorption units to treat refractory organics from gasification has not been extensively investigated. Further testing should be done to determine the exact nature of the organics requiring removal and the efticiency of their removal.

3) Necessary loading rates and other operational parameters are not furnished for the activated sludge plant. To properly evaluate this treatment unit, these operational conditions must be known. A study done on the treatment and reuse of coal conversion wastewaters indicates that PAC-aclivated sludge treatment does not necessarily provide better effluent quality, especially with respect to trace organics removals. 
4) The basis for selection of the evaporation process over other removal processes, such as reverse osmosis, is not available. Reverse osmosis appears to be an attractive technique to remove dissolved solids from coal conversion wastewaters. The effluent from a reverse osmosis unit will be of sufficient quality to be used as a boiler feedwater source. However, further study is needed to determine the extent of membrane fouling under long-term, steady-state operations.

\subsubsection{Wastewater Treatment System Risk Analysis}

The risk assigned to the CONOCO wastewater treatment system is low. However, vital operating conditions for the aeration basin are not furnished and the need for certain individual processes is questionable. Overall, the plant should function if proper operating parameters are selected and should achieve proper removal efficiencies.

Clean Area Storm Sewer

This system has a low risk. A potential problem associated with this area is the determination of when flow is to be pumped to the cooling tower or when treatment must be performed on the runoff before use as makeup. Selection of proper parameters to make the switch in flow direction will depend on runof $f$ characteristics and the operating conditions of the cooling tower.

\section{0iTy Water Sewer}

Treatment of this stream has a low risk if the flow is treated by the complete process wastewater treatment system. The only addition to this system should be a bypass to emergency storage for use when a large chemical spill enters the sewer. In spite of the equalization capacity of the treatment system, a spill of biologically toxic chemicals could inactivate the biological reactor. 


\section{Sanitary Sewer}

The treatment of sanitary sewage is of negligible risk. The characteristics of sewage are well documented and the treatment process used has been proven effective. The quality effluent from the package plant after chlorination is usable as cooling tower makeup water. However, the potential air emissions of chlorinated hydrocarbons from the cooling tower should be examined.

\section{Coal Preparation Area Runoff}

Treatment of this runoff is of low risk. The only pulent1al problem area is that discharges from this area cannot be diverted for treatment if the flow is not acceptable as makeup water. A diversion provision should be adred.

\section{Slag Quench Water}

This area is assigned a low risk. Treatment through the wastewater treatment system should eliminate all impurities in the wastewater.

\section{Process Wastewater}

The treatment system used to purify this wastewater and other wastewaters entering the treatment system is assigned a medium risk. This evaluation is primarily based upon the lack of data on operating conditions for biological treatment.

\subsection{MLGWD INDUSTRIAL FUEL GAS DEMONSTRATION PLANT}

The gasification plant, using the U-Gas Process, is designed tu produce approximately 50 billion Btu/day of product gas having a heating value of $300 \mathrm{Btu} / \mathrm{scf}$ at a site in Shelby County, Tennessee. Ninety-percent of the gas is for industrial fuel. The remaining $10 \%$ is enriched to pipeline quality of $900 \mathrm{Btu} / \mathrm{scf}$. 


\subsubsection{Wastewater Sources and Characteristics}

The wastewater treatment system for this plant can be segregated into five distinct sections. These sections are sanitary wastewater, normal stormwater flow, coal pile runoff, ash quench water, and the gasifier process effluent waters.

Sanitary Sewage

All sanitary sewage generated on the site is sent to a municipal sewage treatment plant. If there are no cross connections between this sewer and other process effluents, this is a satisfactory disposal method.

Stormwater Drainage

All stormwater that falls within the plant limits, except coal storage areas, and all spent service water are treated by a dissolved air flotation unit. Stormwater runoff is expected to be high in suspended solids and to include some oils and BOD. The concentrations indicated by the design engineer for stormwater runoff are within acceptable ranges. The wastewater from this area has BOD from 10 to $50 \mathrm{mg} / \mathrm{l}$, TDS from 150 to $350 \mathrm{mg} / \mathrm{l}$, suspended solids from 50 to $800 \mathrm{mg} / 1$, and $0 i 1$ and grease from 10 to $200 \mathrm{mg} / 1$.

The spent service water is obtained from various sources about the plant. Its pollutant content can only be estimated at this time. Data elsewhere prepared by the design engineer indicate the same stream has as much as 1.5 times the concentrations of pollutants indicated in the mass balance.

Coal Pile Runoff

The plant is presently designed to gasify washed Kentucky \#9 bituminous coal, which has a sulfur content of $3.5 \%$ (moisture and ash free basis). This sulfur content will cause the formation of sulfuric acid when the coal is wet by rain, resulting in an effluent low in $\mathrm{pH}$ and high in suspended solids. The mass 
balance indicates dissolved solids and suspended solids levels of 3,000 and $400 \mathrm{mg} / 1$, respectively, with the $\mathrm{pH}$ of the water at 2.5-3.0. These concentrations are within expected limits for typical coal pile runoff wastewaters.

Ash Quench Water

Extensive testing by the design engineer of the leachate from the ash quench water effluent of the gasifier has indicated that this water is suitable for direct discharge. Dissolved and suspended solids are estimated to be under $200 \mathrm{mg} / 1$ for the ash quench water, with the $\mathrm{pH}$ at about 10 and COD under $30 \mathrm{mg} / 1$. Since this water is constantly recycled, there will be no liquid discharge from this area other than the entrained water in the solids that are removed.

\section{Gasifier Effluent Streams}

The major process effluent streams requiring treatment are the stripped water effluent from sour water stripping, clarifier overflow from gas cooler/scrubber, char-fines filtrate from the utility area, and process condensate from the methane enrichment section. All these processes have been grouped together as combined process influent having the concentrations shown in Figure 5.3.

Sufficient background information to evaluate the composition of this flow stream is not available. Wastewater samples have been collected from the raw-gas quench scrubber at IGT's U-Gas pilot plant and analyzed by Energy Impact Associates. The results at steady-state conditions indicate that the U-Gas pilot plant produces a fairly clean scrubber effluent stream.

\section{Wastewater Treatment System Analysis}

The systems used to treat the various wastewater streams generated by the plant are analyzed in the following sections. The focus of attention is on the adequacy of treatment, based upon expected or possible influents. 


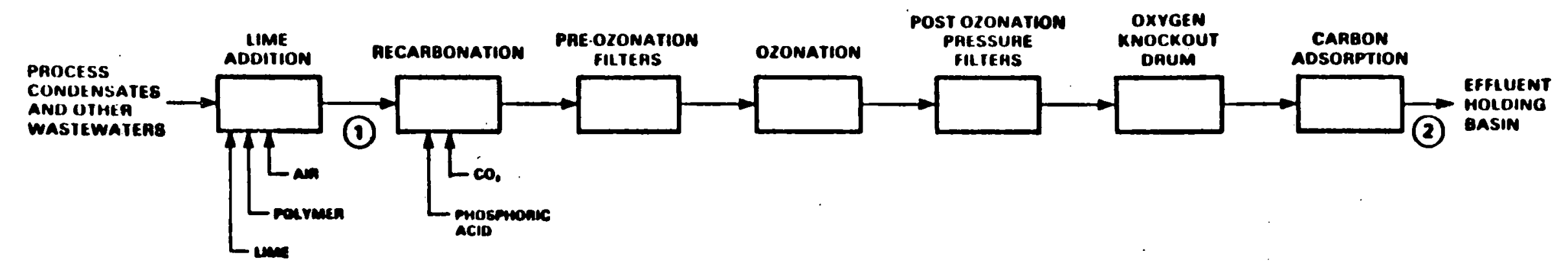

un

\begin{tabular}{l|rr}
\hline STAEAM & (1) & \\
\hline PARAMETER & 2 \\
\hline TDS & $2000-3000$ & $1200-2400$ \\
TSS & $200-300$ & $20-30$ \\
COD & $200-300$ & $25-65$ \\
OGG & $10-20$ & $5-15$ \\
PHENOLS & $<0.26$ & $<0.1$ \\
NH, & 25 & $0.5-3$ \\
H.S & 10 & $<0.1$ \\
CN- & $<0.1$ & $<0.05$ \\
BOD. & - & $10-30$ \\
TOC & - & $5-20$ \\
SCN- & - & $<0.3$ \\
PH & $6-9$ & $6-9$ \\
\hline
\end{tabular}

- all Values are in moll EXCEPT pH

Figure 5.3 MLG.WD Wastewater Treatment Plant Flow Diagram 
Stormwater Drainage

Stormwater, except from coal piles, and spent service water are normally pumped to a dissolved air flotation (DAF) unit for treatment. However, during a storm, excess stormwater is pumped to a holding basin, where it is stored until it can be treated by the DAF unit. This holding basin must be designed to contain the design storm runoff and operated so that this available capacity is maintained during normal operation. In the DAF, suspended solids are reduced by about $70 \%$, from $140 \mathrm{mg} / 1$ to $40 \mathrm{mg} / \mathrm{l}$ and hydrocarbons are reduced by about $90 \%$, to $9 \mathrm{mg} / 1$, with no droplet size exceeding 60 microns.

Treated water from the DAF unit flows into a holding basin, from which it is withdrawn for cooling tower makeup. Stormwater and spent service water are not expected to be high in dissolved solids $(200 \mathrm{mg} / 1)$ and should be suitable for makeup water. Excess makeup water will be discharged to the Mississippi River.

This type of treatment system has proven to be very reliable in extensive use in treating industrial wastewaters. Because a DAF unit is sensitive to hydraulic loading variations, some method of dampening flow variations is required. This is accomplished in this plant by having a storm water basin to hold flows in excess of the flotation unit's capacity. Over a period of years, the stormwater basin may require cleaning to remove accumulated grit and settled solids.

Polymer can also be added to the influent to this treatment system to promote removal of suspended solids and oil. Sludges from the DAF unit are sent to sludge pits, and froth skimmed off the top is sent to a separation tank for oil removal.

It is not anticipated that any normal variations in the influent to the unit. will result in process upsets. It must be pointed out that the flows and concentrations are estimates. If other concentrated flows are combined when the plant becomes operational, the effluent from the flotation unit may not be suitable for the uses selected. 
Coal Pile Runoff

All rain falling on the plant's coal piles is collected and conveyed to a holding basin. From the holding basin, it is pumped to a neutralization tank, where lime is added to raise the $\mathrm{pH}$ to about 8.5. The neutralized wastewater then flows to an aeration basin, where the air causes mixing to occur and oxidizes inorganic materials, causing them to form insoluble precipitates. The wastewater then flows to a clarifier, where under quiescent conditions the precipitate settles to the bottom of the tank and is collected and pumped to the sludge pits. Clarifier effluent flows to the effluent holding basin for storage before reuse in the cooling tower. It is also planned to discharge clarifier effluent to the river as an alternative.

A properly operating flocculation system will remove up to $75 \%$ of the suspended solids (SS) from the wastewaters. With a maximum estimated SS concentration of $800 \mathrm{mg} / 1$, this removal. efficiency would result in an effluent of $200 \mathrm{mg} / 1$ SS. A $94 \%$ removal efficiency was estimated; this is high for a.flocculation operation. Estimated total dissolved solids (TDS) removal efficiencies are in the $90 \%$ range, which is much higher than should be expected. Dissolved solids in the form of $\mathrm{Fe}^{+++}$could account for this high removal rate. However, a more reasonable TDS distribution would include $\mathrm{Cl}^{-}, \mathrm{SO}_{4}=\mathrm{Fe}^{+++}, \mathrm{Al}^{+++}$, and smaller concentrations of other ions. With the $\mathrm{pH}$ elevated to only 8.5, it seems doubtful that a $90 \%$ removal of dissolved solids from a coal pile runoff can be obtained. If $90 \%$ removals are required, the $\mathrm{pH}$ will probably have to be raised to 10. However, because this flow stream is intermittent in nature and relatively small, deterioration of the overall plant effluent as a result of the increased quantities of suspended and dissolved solids from coal pile runoff treatment should be minimal.

Ash Quench water

The ash quench water system is self-contained and reuses the water after agglomerated ash particles are settled out. Settled ash is removed to a solid waste storage site. The storage site will have provisions for collecting leachate 
from the pile and for pumping leachate to a treatment unit. Makeup water for the quench water system is treated effluent from the process water treatment plant.

The slurry is sent to a dewatering bin, where most of the slag is removed. Overflow from the dewatering bin is sent to a clarifier, where additional slag is settled out. Clarifier overflow is cooled and then sent to the gasifier ash quench lock.

\section{Gasifier Effluent Streams}

The treatment of process wastewaters is accomplished by various processes, as shown in Figure 5.3. All major wastewaters are collected and pretreated by lime addition. The lime reacts with dissolved metals and alkalis to form insoluable precipitates. As these precipitates settle, they also remove suspended solids and oils from the wastewater. Oxygen is also bubbled through the water for oxidation and mixing purposes. The solids are precipitated in a clarifier.

The clarifier effluent is pumped through a recarbonation drum. Here, vent gas rich in carbon dioxide is bubbled through the wastewater. The purpose of this step is to lower the $\mathrm{pH}$ to neutral and to restore the alkalinily of the wastewater to a minimum of $1000 \mathrm{mg} / 1$. These values are necessary for proper opera: tion of the downstream biological processes.

The wastewater is then treated with a pressure filter for the removal of solids and oils to prevent plugging of the downstream pressure biological filter. Filtered effluent is pretreated in an ozone contact chamber before being biologically treated in a second pressure filter. The use of a pressure filter, such as the preozonation filter, to remove solids as high as $100 \mathrm{mg} / 1$ to less than $30 \mathrm{mg} / 1$ is not recommended. The filter will clog rapidly and require frequent backwashing. The use of pressure filtration with oily waters is also not recommended for the same reason. Because of the uncertain wastewater composition, this factor could be critical. The usefulness of dual filters in series is also not clear. The purpose of ozonating is to render the organics more susceptible 
to biological degradation. Refractory organics may be reduced at this stage to biodegradable forms.

The ozonated wastewater is pumped through pressure filters for biological removal of organic impurities. The wastewater is then treated in an activated carbon unit and discharged to the effluent holding basin. The expected composition of this effluent is given in Table 5.2. The design of the treatment plant should include a provision for $100 \%$ recycle (zero discharge) retrof it because that regulation may be enforced in the future.

Data Gaps

A review of this treatment plant and the data base indicates the following data deficiencies.

1) The purpose of the lime treatment step is to reduce the $200-300 \mathrm{mg} / 1$ of suspended solids to $50 \mathrm{mg} / \mathrm{l}$. More data are needed on the effects of this step on other pollutants, such as oils, and dissolved solids, specifically $\mathrm{Ca}^{++}, \mathrm{Mg}^{++}, \mathrm{Fe}^{++}$, etc., and alkalis.

2) The estimates generated in the design report are based upon wastewaters from other similar processes and pilot plant data. The wastewater con-. centrations assumed for this gasification process are not consistent. Phenol exerts a theoretical COD of 2.4 times its concentration. With a phenol concentration of $200 \mathrm{mg} / 1$, the minimum COD would be $480 \mathrm{mg} / 1$. This is assuming that all the organics are phenolic in nature, which is a minimum condition. The COD assumed by the design engineer is $300 \mathrm{mg} / \mathrm{l}$, which does not account for all the phenols. Since other soluble organics are present, the $C O D$ should be in excess of $500 \mathrm{mg} / 1$. These wastewaters should be characterized before the treatment system is designed.

3) The ozonation system is designed to break organics into a more biodegradable form. It is not fully understood from experimentation what effect ozone has upon gasification wastewaters and what dosages are 
Table 5.2 Expected Effluent Quality of MLGW Wastewater Treatment System

Component

Total dissolved solids (TDS)

Total suspended solids (TSS)

Chemical oxygen demand (COD)

Five-day biological oxygen demand $\left(\mathrm{BOD}_{5}\right)$

$0 i 1$ and grcasc

Priority organics

$\mathrm{NH}_{3}-\mathrm{N}$

Thiocyanate $\left(\mathrm{SCN}^{-}\right)$

Hydrogen sulfide $\left(\mathrm{H}_{2} \mathrm{~S}\right)$

Phenols

Cyanide $\left(\mathrm{CN}^{-}\right)$

Silver

Arsenic

Beryllium

Cadmium

Chromium

Magnes ium

Mercury

Nickel

Lead

Antimony

Selenium

Thallium

Zinc

$\mathrm{pH}$

Source: Ref. 48, P 2-7

\section{Concentration (mg/liter)}

\author{
1200 to 2400 \\ 20 to 30 \\ 25 to 65
}

¿

10 to 30

5 to 15

$<0.5$

0.5 to 3

$<0.3$

$<0.1$

$<0.1$

$<0.05$

0.005

0.3

0.005

0.05

0.06

0.03

0.002

0.03

0.5

0.03

0.1

0.03

0.3

6-9 
required. There is also no information supplied by the design engineer on expected results from the ozonation system.

4) The purpose of the post-ozonation filter is unclear. In one part of the design report, stated function of the filter is to remove suspended solids to less than $10 \mathrm{mg} / 1$. In another, its function is substantial removal of organic pollutants, which it cannot do. If biological growth on the filter is intended to remove organics, operational problems can be expected. To remove the organics from the wastewater as intended would require an amount of organisms that would cause rapid blinding of the filter. This would result in short filtration times and excessive backwashing. It is also unknown where the accumulated biomass originates, as during backwash cycles all solids would be removed from the filter bed. To maintain biological activity, the backwashed bed would have to be innoculated with organisms before coming on line. This is obviously impractical.

5) It is not stated in the design report where removals of major pollutants, such as ammonia, phenol, TOC, $C O D$, and BOD, are to occur. Some assignment must be made of where these pollutants are being removed so that a proper evaluation of the treatment system can be made.

6) The use of this entire process wastewater treatment system is questionable. The technology behind these treatment units has not been proven lo be effective with gasification, or any other, wastewaters. Although this treatment train has been used in a pilot plant for an industrial wastewater, there are no data available on removal efficiencies.

The unit processes included in this treatment train have numerous operational problems that should be investigated before inclusion in a demonstration plant design. The design engineer even states that the technology for this plant will be proven in three to four years. It is reconmended that, as a minimum, the two pressure filters and the ozonation unit be replaced by an activated sludge unit and a filter. Provisions 
could be added to the plant to connect the filters and ozone unit in parallel operation, if desired. There is no provision for the equalization of flow into the treatment plant as designed. Because variations in process wastewaters are detrimental to biological processes, some form of equalization should be included.

7) The use of activated carbon to treat refractory organics formed during gasification processes has not been shown to be entirely successful. More experimentation should be done to eliminate questions concerning its use.

8) The effluent of treated coul pile runoff and cooling tower blowdown would not be suitable for either discharge or reuse after simple lime treatment. Dissolved solids may be lowered to acceptable levels through dilution with other flow streams. Lime treatment will remove metals and alkalis, but not al 1 dissolved solids. A question is raised as to the accuracy of the estimated low dissolved solids $(600-1000 \mathrm{mg} / \mathrm{l})$ concentrations and the high oil and grease levels in the cooling tower blowdown.

\subsubsection{Wàstewater Treatment System Risk Analysis}

Overall, the wastewater treatment system is assigned a high risk because of the processes selected to treat the process wastewater. Wastewater compositions are unknown and the assumed characteristics are not internally consistent.

The treatment system employs untried technology and is therefore considered of high risk.

\section{Sánitary Sewage}

This area is assigned a negligible risk. The sewage will be treated in a conventional manner and no problems are expected from this area. 


\section{Stormwater Drainage}

This treatment is assigned a low risk because the treatment of stormwater by DAF units should render an effluent suitable for reuse or discharge.

\section{Coal Pile Runoff}

Treatment of this wastewater is considered to be of low risk. Although the dissolved solids will not be removed to levels suitable for discharge or reuse by themselves, expected dilution should make it usable.

Ash Quench Water

This treatment is assigned a low risk. The slag has been shown to be relatively inert to leaching.

Gasifier Effluent Stream

The treatment of this wastewater is considered a high risk. The wastewater composition is unknown and the values assumed for wastewater composition are internally inconsistent.

The basis for the treatment plant relies upon data from a pilot plant treating an unrelated wastewater. Reducing this risk can be accomplished by obtaining wastewater characterizations from the U-Gas process, performing treatability studies on the wastewater, and using gasification treatability studies as a basis for a treatment plant design.

Since the effluent from the MLGWD wastewater treatment system will be discharged to the Mississippi River, a buoyant plume model was applied to assess the impacts from normal plant operation. The results are given in Table 5.3. The behaviors of ammonia nitrogen, cadmium, cyanide, hydrogen sulfide, lead, mercury, phenol, and selenium are of particular interest because their proposed maximum concentrations in the MLGWD demonstration plant effluent exceed water quality criteria 
Table 5.3

Comparison of MLG Demonstration Plant Effluent with Water Quality Criteriad

\begin{tabular}{|c|c|c|c|c|c|c|}
\hline $\begin{array}{l}\text { Chemical } \\
\text { Constitutent }\end{array}$ & $\begin{array}{c}\text { Water } \\
\text { Quality Criterion } \\
\text { Concentration } \\
C_{r}\end{array}$ & $\begin{array}{l}\text { Effluent } \\
\text { Limitations } \\
\quad \text { from } \\
\text { Industrial } \\
\text { Wastewater } \\
\text { Treatmentb } \\
\end{array}$ & $\begin{array}{c}\text { Maximum } \\
\text { Concentrat ion } \\
\text { in IFGDP } \\
\text { effluent } \\
C_{e}\end{array}$ & $\begin{array}{l}\text { Maximum } \\
\text { Ambient } \\
\text { Concentration } \\
C_{a}\end{array}$ & $\begin{array}{l}\text { Maximum } \\
\text { Dilut ion } \\
\text { Required } \\
\text { to Meet } \\
\text { Criterionc } \\
\end{array}$ & $\begin{array}{l}\text { tance } \\
\text { instream } \\
\text { m Outfall } \\
\text { terion } \\
\text { (m) } \\
\end{array}$ \\
\hline Ammonia nitrogen & $\begin{array}{l}0.02 \text { as unionized } \\
\text { ammonia (assumed) } \\
\text { to be approximately } \\
\text { equal to } 1 \mathrm{mg} / \mathrm{liter} \\
\text { of total ammonia } \\
\text { nitrogen) }\end{array}$ & Not listed & 0.5 to 3.0 & 0.84 & 10 & $<23$ \\
\hline Cadmium & 0.0012 & 0.01 & 0.05 & $<0.01$ & $\begin{array}{l}\text { Ca may exceed } \\
\text { criteria; chemi- } \\
\text { cal detection } \\
\text { limits too insen- } \\
\text { sitive }\end{array}$ & $\begin{array}{l}\text { Criterion } \\
\text { may not be } \\
\text { met becaus } \\
\text { of high } C_{a}\end{array}$ \\
\hline Chromium & 0.05 & 3.0 & 0.06 & 0.016 & 1.3 & $\begin{array}{l}\text { Immediately } \\
\text { at outfall }\end{array}$ \\
\hline Cyanide & 0.005 & 0.05 & $<0.05$ & 0.009 & $\begin{array}{l}\bar{C}_{a} \text { exceeds } \\
\text { criteria } \\
\text { frequently }\end{array}$ & $\begin{array}{l}\text { Criterion } \\
\text { may not be } \\
\text { met because } \\
\text { of high } c_{a} \text {; } \\
\text { reduced to } \\
0.0061\end{array}$ \\
\hline Hydrogen Sulfide & $\begin{array}{l}0.002 \text { as undis- } \\
\text { siciated hydrogen } \\
\text { sulfide }\end{array}$ & Not listed & $<0.1$ & $\begin{array}{l}\text { No data } \\
\text { Assume } 0\end{array}$ & 50 & $<65$ \\
\hline Lead & 0.05 & 0.01 & 0.5 & 0.022 & 17 & $<23$ \\
\hline Mercury & $0.05 \mathrm{ug} /$ liter & $50 \mathrm{ug} / 1$ iter & 2 ug/liter & I ug liter & $\begin{array}{l}C_{a} \text { exceeds cri- } \\
\text { teria; chemical } \\
\text { detection limits } \\
\text { too insensitive } \\
\text { to calculate how } \\
\text { frequently }\end{array}$ & $\begin{array}{l}\text { Criterion } \\
\text { may not be } \\
\text { met because: } \\
\text { of high } C_{a}\end{array}$ \\
\hline Phenol & 0.001 & 1.0 & $<0.01$ & 0.025 & $\begin{array}{l}C_{a} \text { exceeds cri- } \\
\text { teria consistentiy }\end{array}$ & $\begin{array}{l}\text { Criterion } \\
\text { may not be } \\
\text { met be- } \\
\text { cause of } \\
\text { high } C_{a}\end{array}$ \\
\hline Selenium & 0.01 & 0.01 & 0.1 & 0.01 & $\begin{array}{l}C_{a} \text { exceeds } \\
\text { criteria } \\
\text { occasionally }\end{array}$ & $\begin{array}{l}\text { Criterion } \\
\text { may not be } \\
\text { met he- } \\
\text { cause of } \\
\text { high } C_{a}\end{array}$ \\
\hline \multirow[t]{2}{*}{$\begin{array}{l}\text { Physical } \\
\text { Propicity : } \\
\text { Temperature, } \\
{ }^{\circ} \mathrm{C}\end{array}$} & Summer: 30.5 & Not Listed & 26.7 & 28.9 & $\begin{array}{l}\text { Criterion met } \\
\text { without dilu= } \\
\text { tion }\end{array}$ & $\begin{array}{l}\text { Criterion } \\
\text { met prinr } \\
\text { to dis- } \\
\text { enarge }\end{array}$ \\
\hline & Winter: $3=3.3$ & & 18.3 & 0.3 & 6 & 5 \\
\hline
\end{tabular}

a Data taken from ER, Sect. $3 A$ and $4 A$; chemical constituents as mg/liter unless otherwise specified.

b Data from Bureau of National Affairs; "Tennessee Effluent Limitations and Standards," Environ. Reporter 916: 1001-1002 (1978).

C Calculated by the following equation: $\left(C_{e}-C_{a} / C_{r}-C_{a}\right)$

Source: Ref. 48, P 4-13 
(Table 5.3). In addition, effluent concentrations of cadmium, lead, and selenium exceed recommended effluent limitations for treated industrial wastewaters. However, further modeling results indicate that, even under the most conservative conditions, chemical constituents in the plant effluent are rapidly diluted by the Mississippi River. However, more stringent future regulations (e.g., zero discharge) may require redesign, or retrofit, of the wastewater treatment system. 


\section{SECTION 6 - CONCLUSIONS}

From this investigation of state-of-art coal gasification wastewater treatment, the following conclusions have been drawn.

1). It has been reported in the literature that gasification process wastewaters could be treated to levels sufficient for discharge under current regulations.

2) Although commercial scale systems to achieve $100 \%$ recycle of process wastewaters are in use, $100 \%$ recycle operation with gasification wastewaters is unproven. The reliability of the advanced treatment processes has not been substantiated and knowledge of the characteristics of wastewaters is not complete enough to predict the possible buildup of contaminants, or the effects of buildup, during extended recycle operation. The absence of information in this area is a substantial data gap.

3) The inability of many pilot plants to achieve long-term, steady-state operation has made characterization of wastewaters difficult. The low wastewater productions of many pilot plants has also limited treatability studies. Accordingly, a question arises concerning the applicability of current characterization and treatability data to larger scale demonstration plants. 'It is suggested that treatability data be continuously revised as gasification processes evolve.

4) It should be understood that the gasification industry in the U.S. is in its infancy. At the current stage of development answers to all design questions are not available. It is necessary to utilize the best available information in the design of wastewater treatment modules, while maintaining sufficient flexibility for future modifications as required.

5) Phenol and ammonia recovery/removal processes tend to normalize wastewaters from different gasifiers because of the $99.9 \%$ removals of phenolic compounds and ammonia. This allows the use of one treatment plant type for most 
gasification wastewater treatment rather than a distinct plant for each gasification process. If the recovery of ammonia and phenols is not economical, ical, the same removal processes may be used to remove these compounds to levels that do not inhibit downstream biological processes. This can also be accomplished by diluting the wastewater, but dilution will also increase the size and costs of the treatment plant. The choice between a removal system or dilution should be made on a plant-by-plant basis.

6) It has been determined that wastewater characteristics are sensitive to gasification process conditions. This makes it important to conduct treatability studies on wastewaters from a gasifier operating at the same condition as the the plant under design.

7) Further work will be required to optimize treatment processes already shown to be effective. The most significant step in this direction would be the completion and operation of demonstration-size and commercial-size plants. Studies of alternative treatment processes and system optimization should be done at full-scale conditions.

8) Gasification process wastewaters, in general, are highly buffered, making $\mathrm{pH}$ adjustment difficult until much of the carbon dioxide has been removed from solution.

9) A flow equalization basin is recommended prior to biological processing to dampen potentially toxic fluctuations in influent concentrations.

10) Biological processes have been shown to remove soluble organic pollutants to levels suitable for discharge under existing effluent regulations. Depending upon the influent Chemical oxygen Demand (COD), some dilution may be required for stable operation. Satisfactory treatment can be obtained with COD concentrations up to $4000 \mathrm{mg} / 1$ and loadings in the range of 0.3 to $0.5 \mathrm{mg} \mathrm{COD} / \mathrm{mg} \mathrm{MLSS} /$ day. The influent phenols concentration should be limited to $1500 \mathrm{mg} / \mathrm{l}$ and ammonia to below $600 \mathrm{mg} / 1$ for stable operation. Nitrification has been observed in some cases but has been inconsistent. 
11) The ability of advanced treatment processes to treat gasification wastewater to the extent necessary to achieve zero discharge has had little study. The absence of information in this area is a substantial data gap.

12) Much of the available data are for analysis of condensates from process development units (PDUs) or pilot plants. It should be expected that any changes anticipated between pilot plant and commercial scale gasifier operating conditions may have significant effects on gasifier effluent production, especially with respect to organic contamination. It should also be recognized that data available now are not of design quality for a larger scale commercial operation. Thus, scalability of the pilot plant data is still a major issue. Factors to consider may include coal type and pretreatment, gasifier geometry, configuration and operating parameters, and raw-gas quench system design and operation.

13) The technol ogy for phenol and ammonia removal/recovery is proven and is commercially available. 


\section{SECTION 7 - RECOMMENDATIONS}

The following program recommendations are designed to fill data gaps that presently exist in the treatment of coal gasification wastewaters. Further benchscale studies, with the exception of those proposed below, will not yield significantly valuable data. The scale of study must be increased. This point is important because larger scale gasification plants are years into the future. However, the continued generation of useful data until larger plants come on stream is required. These recommendations are proposed to meet that requirement.

\section{General recommendations}

1) All design decisions for coal gasification wastewater facilities should be based upon the concept of $100 \%$ reuse of the wastewaters generated. This is the worst case condition and will eliminate future modifications to designs or retrofits to facilities when stricter effluent standards are implemented.

2) Bench-scale biological treatment should be applied only to wastewaters from gasification processes that are the closest to commercial development, and then only for significant process variations or system optimization.

3) The environment of the testing facilities should be shifted from the laboratory to the pilot plant site. With this shift, the wastewaters can be treated on an as-produced basis and will be subjected to the actual effects of ambient conditions rather than to the closely controlled conditions of the laboratory.

\section{Program recommendations for further bench-scale experimentation}

1) Studies of the use of advanced wastewater treatment processes for water recycle should be performed. Processes to be investigated should include reverse osmosis, evaporation, electrodialysis, ozonation, activated carbon, and ultrafiltration. The scale of the experiment should be as large as 
the supply of available wastewater permits. The treatment processes should be arranged so that the effluent from one unit operation is the influent to the next. This will simulate the conditions at commercial scale. The overall purpose of these studies is to remove refractory organics and dissolved solids in a most cost-effective manner.

2) Experimentation should also be performed to determine if ozonation of wastewaters prior to biological treatment will convert refractory organics into a more biodegradable form. If this is the case, the treatment of organics can be greatly simplified. The scope of the work should be as large as possible within the limitations on wastewater availability and the size of the biological treatment units.

\section{Program recommendations for pilot scale or larger experimentation}

1) Present treatability studies have been limited in scope because of small wastewater production from the existing gasification pilot plants. It is recommended that wastewater from metallurgical coking plants be used to simulate gasification wastewaters. The wastewaters from gasification and metallurgical coking processes are similar and the coke plant will produce a wastewater flow large enough to be treated on a continuous basis. The latter point is especially important in assessing the stability of various unit processes because the wastewater composition varies with time. The treatment processes and the conditons under wich they will be operated should be determined in bench scale studies. It should be pointed out, however, that optimization of process parameters will not be possible until demonstration-size or larger gasification facilities are in operation.

2) Another alternative would be to perform treatability studies on wastewaters from commercial coal gasification plants operating outside the U.S. In this case, gasification wastewaters can be treated in full-scale units. Treating actual gasification wastewaters would make it possible to optimizate the operating conditions for the treatment units. 


\section{SECTION 8 - GLOSSARY}

ACIDITY

The quantitative capacity of aqueous solutions to react with alkalinity. It is measured by titration with a standard solution of a base to a specified end point. Usualiy expressed as milligrams per liter of calcium carbonate.

ALKAL INITY

The capacity of water to neutralize acids, a property imparted by the water's content of carbonates, bicarbonates, hydroxides, and occasionally borates, silicates, and phosphates. It is expressed in milligrams per liter of equivalent calcium carbonate.

ANAEROBIC

WASTE

TREATMENT

BI OCHEMICAL OXYGEN

DEMAND (BOD)

BIOLOG ICAL

WASTEWATER

TREATMENT

BUFFER

CAUSTIC

(Caustic Soda)
Waste stabilization brought about through the action of microorganisms in the absence of air or elemental oxygen. Usually refers to waste treatment by methane fermentation.

The quantity of oxygen used in the biochemical oxidation of organic matter in a specified time, usually 5 days, at a specified temperature, and under specified conditions.

Forms of wastewater treatment in which bacterial or biochemical action is intensified to stabilize, oxidize, and nitrify the unstable organic matter present. Intermittent sand filters, contact beds, trickling filters, and activated sludge processes are examples.

Any of certain combinations of chemicals used to stabilize the $\mathrm{pH}$ values or alkalinities of solutions.

Sodium hydroxide. 
CHEMICAL

COAGULATION

CHEMICAL

OXYGEN

DEMAND (COD)

CHEMICAL

PRECIPITATION

CHLORI NATION

CLARIFICATION

COAGULATION

DIALYSIS
The destabilization and initial aggregation of colloidal and finely divided suspended matter by the addition of a flocforming chemical.

A measure of the oxygen-consuming capacity of inorganic and organic matter present in water or wastewater. It is expressed as the amount of oxygen consumed from a chemical oxidant in a specific test. It does not differentiate between stable and unstable organic matter and thus does not necessarily correlate with biochemical oxygen demand.

(1) Precipitation induced by addition of chemicals. (2) The process of softening water by the addition of lime or lime and soda ash as the precipitants.

The application of chlorine to water or wastewater, generally for disinfection, but frequently for oxidation purposes.

Any process or combination of processes, the primary purpose of which is to reduce the concentration of suspended matter in a liquid.

In water and wastewater treatment, the destabilization and initial aggregation of colloidal and finely divided suspended matter by the addition of a floc-forming chemical or by biological processes.

The separation of a colloid fram a substance in true solution by allowing the solution to diffuse through a semi-permeable membrane. 
DISSOLVED

SOLIDS

FLOCCULATION

FLOTATION

FOOD TO

MICRDORGANISM

RATIO (F/M)

GREASE

HARDNESS
Theoretically, the anydrous residues of the dissolved constituents in water. Actually, the term is defined by the method used in determination. In water and wastewater treatment, the Standard Methods tests are used.

In water and wastewater treatment, the agglomeration of colloidal and finely divided suspended matter after coagulation by gentle stirring by either mechanical or hydraulic means. In biological wastewater treatment where coagulation is not used, agglomeration may be accomplished biologically.

The rising of suspended matter to the surface of the liquid in a tank as scum by aeration, the evolution of gas, chemicals, electrolysis, heat, or bacterial decomposition, and the subsequent removal of the scum by skimming.

Measurement of a system's organics loading rate expressed as unit mass per unit reactor volume per unit time.

In wastewater, a group of substances including fats, waxes, free fatty acids, calcium and magnesium soaps, mineral oils, and certain nonfatty materials. The type of solvent and method used for extraction should be stated for quantification.

A characteristic of water, imparted by salts of calcium, magnesium, and iron, such as bicarbonates, carbonates, sulfates, chlorides, and nitrates, that cause curdling of soap, deposition of scale in boilers, damage in some industrial processes, and sometimes objectionable taste. It may be determined by a standard laboratory procedure or computed from the amounts of calcium, magnesium, iron, aluminum, manganese, barium, strontium, and zinc, and is expressed as equivalent calcium carbonate. 
I NDUSTRIAL

WASTES

INORGANIC

MATTER

LAGOON

LIME

MIXED-L IQUOR

SUSPENDED SOLIDS

(MLSS)

MI XED-L IQUOR

VOL.ATILE

SUSPENDED

SOLIDS (MLVSS)

NEUTRALIZATION

NITRIFICATION
The liquid wastes from industrial processes, as distinct from domestic or sanitary wastes.

Chemical substances of mineral origin, or more correctly, not of basically carbon structure.

(1) A shallow body of water, as a pond or lake, which usually has a shallow, restricted inlet from the sea. (2) A pond containing raw or partially treated wastewater in which aerobic or anaerobic stabilization occurs.

Any of a family of chemicals consisting essentially of calcium hydroxide made from limestone (calcite), which is composed almost wholly of calcium carbonate or of a mixture of calcium and magnesium carbonates.

An engineering measurement of cell population on the basis of mass concentration expressed as milligrams per liter. Materials retained on a specified filter (normally glass fiber filter disks) dried at $105^{\circ} \mathrm{C}$ is reported as MLSS. This material may include organic constituents of waste, inorganic particles, and dead cells as well as viable cells.

An alternative engineering measurement of cell population. The solids that volatilize at $550^{\circ} \mathrm{C}$ expressed as milligrams per liter.

Reaction of acid or alkali with the opposite reagent until the concentrations of hydrogen and hydroxyl ions in the solution are approximately equal.

The conversion of nitrogenous matter into nitrates by bacteria. 
ORGANIC MATTER - Chemical substances of animal or vegetable origin, or, more correctly, of basically carbon structure, comprising compounds consisting of hydrocarbons and their derivatives.

ORGANIC NITROGEN Nitrogen combined in such organic molecules as protein, amines, and amino acids.

OXIDATION

The addition of oxygen to a compound. More generally, any reaction that involves the loss of electrons from an atom.

OXIDATION POND A basin used for retention of wastewater before final disposal, in which biological oxidation of organic material is effected by naturally or artifically accelerated transfer of oxygen to the water from air.

$\mathrm{pH}$ The reciprocal of the logarithm of the hydrogen ion concentration. The concentration is the weight of hydrogen ions in grams per liter of solution. Neutral water, for example, has a $\mathrm{pH}$ value of 7 and a hydrogen ion concentration of 10-7.

PRIMARY

TREATMENT

(1) The first major (sometimes the only) treatment in a wastewater treatment works, usually sedimentation. (2) The removal of a substantial amount of suspended matter but little or no colloidal and dissolved matter.

SANITARY SEWER A sewer that carries liquid-and water-carried wastes from residences, commercial buildings, industrial plants, and institutions, together with minor quantities of ground-storm and surface waters that are not admitted intentionally.

SECONDARY

The treatment of wastewater by biological methods after priWASTEWATER mary treatment by sedimentation.

TREATMENT 
SED IMENT AT ION

The process of subsidence and deposition of suspended matter carried by water, wastewater, or other liquids, by gravity. It is usually accomplished by reducing the velocity of the liquid below the point at which it can transport the suspended material. Also called settling.

SLUDGE DIGESTION The process by wich organic or volatile matter in sludge is gasified, liquified, mineralized, or converted into more stable organic matter through the activities of either anaerobic or aerobic organisms.

SLUDGE

THICKENING

The increase in solids concentration of sludge in a sedimentation or digestion tank.

SLUDGE VOLUME INDEX (SVI)

SRT

SUSPENDED SOLIDS

TOTAL ORGANIC CARBON (TOC)
The volume in milliliters occupied by $1 \mathrm{~g}$ of activated sludge after settling the aerated liquor for 30 minutes.

Sludge retention time.

(1) Solids in suspension in water, wastewater, or effluent.

(2) Solids in suspension that can be removed readily by standard filtering procedures in a laboratory.

The total organic carbon concentration in a wastewater is a measure of pollution, and these values can often be correlated with COD and occasionally BOD values. The organic carbon is evaluated either by acidifying and purging the sample of all inorganic carbon before analysis or by providing a dual combustion tube for total carhon analysis, and a low temperature combustion tube for inorganic carbon analysis, the difference being taken as total organic carbon. 
TOTAL OXYGEN DEMAND. (TOD)

TOTAL SOLIDS

TURBIDITY
The total oxygen demand of a substance as measured includes organic and inorganic substances, but at varying reaction efficiencies. The chemical reactions involved include: (1) Carbon is converted to $\mathrm{CO}_{2} ;$ (2) hydrogen is converted to water; (3) nitrogen in a 3-valence state is converted to nitric oxide; (4) the sulfite and sulfide ions are partially converted to sulfate.

The sum of dissolved and undissolved constituents in water or wastewater, usually stated in milligrams per liter.

(1) A condition in water or wastewater caused by the presence of suspended matter, resulting in the scattering and absorption of light rays. (2) A measure of fine suspended matter in liquids. (3) An analytical quantity usually reported in arbitrary turbidity units determined by measurements of light diffraction. 


\section{SECTION 9 - REFERENCES}

1. Goldstein D. J. and D. Yung, Water Conservation and Pollution Control in

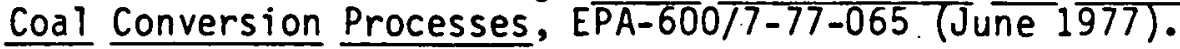

2. Hicks, R. E., D. J. Goldstein, F. B. Senfert, and I. W. Wei, Wastewater Treatment in Coal Conversion, EPA-600/7-79-133 (June 1979).

3. Cost of Clean Water, Volume III, Industrial Waste Profiles, U.S. Department of the Interior, (1967).

4. Klein, J. A. , et al., Assessment of Environmental Control Technology for Coal Conversion Aqueous Wastes, ORNL/TM-6263, Oak Ridge National Laboratory, Tennessee, (1978).

5. Improved Water Management of Coal Conversion Processes by Preliminary Absorption of Halides, by Davy McKee for US-DOE, Contract No. EE-77-C-024375, December 1979.

6. Cleland, J. G., et al., Pollutants from Synthetic Fuels Production: Coal

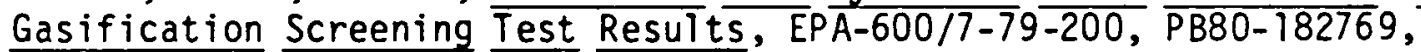
(1979).

7. Magee, E. M., et al., Potential Pollutants in Fossil Fuels, EPA-R2-73-249 by Esso Research and Engineering Company for the U.S. Environmental Protection Agency, (1973).

8. Fillo, J. and M. J. Massey, "Fate of Phenols During the Gasification of Coal", Symposium Proceeding: Environmental Aspects of Fuel Conversion Technology, IV, April 1979, Hollywood, FL, EPA-600/07-79-217, pp. 279-302, (1979).

9. Nakles, D. V., Significance of Process Variables on Liquid Effluent Production in Coal Gasification, FE-2496-19, for U.S. Department of Energy by Carnegie-Melion University, (1978).

10. Braunstein, H. M., et al., (Editors), Environmental, Health, and Control Aspects of Coal Conversion: An Information Overview, Vol. I, ORNL/EIS-94, for U.S. Energy Research and Development Administration by Oak Ridge National Laboratory, (1977).

11. Yu, K. Y., and G. M. Crawford, Characterization of Coal Gasification Ash Leachate Using the RCRA Extraction Procedures, present ed at USEPA Symposium, Environmental Aspects of Fuel Conversion Technology, V, St. Louis, Mis souri, Sept enter $16-19,1980$.

12. Somerville, M. H. and J. L. Elder, A Comparison of Trace Element Analysis of North Dakota Lignited Laboratory Ash with Lurgi Gasifier Ash and Their Use in Environmental Analysis, University of North Dakota, ND.

13. Environmental Review of Synthetic Fuels, : IERL-RTP, EPA, Vol. 4, No. 1, March, 1981. 
14. McMichael, W. J., et al., Synthane Gasifier Effluent Streams, PERC/RI-77/4, U.S. Energy Research and Devel opment Administration (1977).

15. Johnson, G. E., et al., Treatability Studies of Condensate Water from Synthane Coal Gasification, PERC/RI-77/13, Pitt sburgh Energy Research Center, Pittsburgh, PA., (1977).

16. Bromel, M. C. and J. R. Fleeker, Biotreating and Chemistry of Waste Waters from the South African Coal, Oil and Gas Corporation (SASOL) Coal Gasification Plant, North Dakot a University, $(1976)$.

17. Bombaugh, K. J. et al., Environmental Assessment: Source Test and Evaluation Report-Lurgi (KOSOVO) Medium-Btu Gasification, Phase I, EPA-600/7-79-190, (1979).

18. Fil 10, J. P. and M. J. Massey, Analys is of RA-2l Effluent Data: GFERC Slagging Fixed-Bed Gasifier, FE-2496-24, for U.S. Department of Energy by Carnegie-Mellon University, (1978).

19. Luthy, R. G. and S. G. Bruce, Analys is of GFERC Wastewater Samples, RUN RA-16, FE-2496-15, for U.S. Department of Energy by Carnegie-Mellon University, (1978).

20. Massey, M. J., R. G. Luthy, and M. J. Poehan, A Synops is of C-MU Technical Contributions to the DOE Coal Gasification Environmental Assessment Program, FE-2496-39, Environmental Studies Institute, Carnegie-Mellon University, Pittsburgh, PA, (1978).

21. Luthy, R. G., Design of Treatability Studies on Hygas Coal Gasification Pilot Plant Wastewaters, FE-2496-13, for U.S. Department of Energy by Carnegie-MelTon University, (1978).

22. $\mathrm{CO}_{2}$ Acceptor Process Gasification Pilot Plant, Environmental Characterization, Fina Report, Vol. II, Book 7 of 3, FE-1734-44, (Vol. II) (Book 1), CONOCO Coal Devel opment Comp. and Radian Corp., (1978).

23. Nakles, D. V., et al., Characterization of Effluents from the Bi-Gas Pilot Plant, FE-2496-21, for Department of Energy DOE by Carnegie-Mel 1on Univers1ty, (1978).

24. Review of the Current Out look for High Btu Gas Demonstration Projects, Nationat Coal As sociation, (197\%).

25. Stamaudis, V. C. and R. G. Luthy, "Determination of Biological Removal of Organic Constituents in Quench Waters from High-Btu Coal Gasification Pil ot Plants", Water Research, Vol: 14, Pp. 1143-1156, (1980).

26. Schlinger, W. G., and G. N. Richter, Process Pollutes Very Little, Hydrocarbon Processing, October 1980, pp. 66-70. 
27. Hossain, S. M., et al., Applicability of Coke Plant Control Technologies to Coal Conversion, EPA-600/7-79-184, for U.S. Environment al Protection Agency by Catalytic, Inc., (1979).

28. Kostenbader, P. D. and J. W. Flecksteiner, "Biological Oxidation of Coke Plant Weak Ammonia Liquor", Journal of the Water Pollution Control Federation, Vol. 41, No. 2, pp. 199-207, (1969).

29. Jungten, H. and J. Klein, "Purification of Wastewater from Coking and Coal Gasification Plants using Act ivated Carbon", Reprints of 168th National Meeting of the American Chemical Society, Vol. 19, No. 5, Atlantic City, NJ, (1974).

30. Somerville, M. H., et al., A Comparative Study of Effluents and Their Control from Four Dry Ash Lurgi Gasification Plants, C00-4035-2 (Sect ion B), for U.S. Department of Energy by University of North Dakota, (1978).

31. Adams, C. E., Treatment of a High Strength Phenol ic and Ammonia Wastestream by Single and Multi-Stage Activated sludge Processes, Associated Water and Air Resources Engineers, present ed at Purdue Industrial Waste Conference, Purdue University, (1974).

32. Singer, P. C., et ar., Treatability and Assessment of Coal Conversion Wastewaters: Phase I, EPA-600/7-79-248, (1979).

33. Slack, W. A. , Biological Treatability of Gasifier Wastewater, METC/CR-79/24, Morgantown Energy Technology Center, Morgantown, West Virginia, (1979).

34. Luthy, R. G. and J. T. Tallon, Biological Treatment of Hygas Coal Gasification Wastewater, FE-2496-43, for U.S. Department of Energy by CarnegieMelTon University, (1978).

35. Luthy, R. G. and J. R. Campbell, Treatment of Phenolic Coal Gasification Effluents, Carnegie-Mellon University, presented at the 2nd United States Department of Energy Environmental Control Symposium, Reston, VA, (1980).

36. Luthy, R. G. and J. T. Tallon, Experimental Analysis of Biological Oxidation Characteristics of Hygas Coal Gasification Wast ewater, FE-2496-27, for U.S. Department of Energy by Carnegie-Mellon University, (1978).

37. Luthy, R. G., Treatment and Reuse of Coal Conversion Wastewaters, CarnegieMellon University, presented at the Symposium on Environmental As pects of Fuel Conversion Technology, V, St. Louis, MO, (1980).

38. Luthy, R. G., D. J. Sekel, and J. T. Tallon, "Biological Treatment of Synthetic Fuel Wastewater", Journal of the Environmental Engineering Division, American Society of Civil Engineering, Vol. 106, No. EE3, pp. 609-629, (1980).

39. Suidan, M. T., et al., Treatment of Phenolic Wastewater with Anaerobic Activated. Carbon Filters. FE-2756-T 1, for U.S. Department of Energy by Georgia Institute of Technology, Atlanta, Georgia, (1979). 
40. Ragan, J. L., Celanese Chemical Company, Inc. Experience with Anaerobic Filters, presented at DOE/EPA Seminar/Workshop, January $\overline{9-10}, \overline{1980, \text { Howey- }}$ in-the-Hills, FL.

41. Lee, D. D., et al., "Fluidized-Bed Bioreactor for Coal-Conversion Effluents", Journal of the Water Pollution Control Federation, Vol. 51, No. 5, pp. 974- $\overline{984},(1 \overline{979})$.

42. Vadja, G.F., Reuse of Wastewater from the Hygas Coal Gasification Process, Masters Thesis, Ilinois Institute of Technology, (1980).

43. Luthy, R. G., et al., A Synopsis of Wastewater Treatability Studies Performed on Hygas Pilot Plant Quench Condensate at Carnegie-Mellon University, PA, (1978).

44. Neufeld, R. D. and A. A. Spinola, "Ozonation of Coal Gasification Plant Wastewater", Environmental Science \& Technology, Vol. 12, No. 4, (1978).

45. Klemetson, S. L. and M. D. Scharbow, "Filtration of Phenolic Compounds in Coal Gasification Waste Water", Journal of the Water Pollution Control Federation, Vol. 51, No. 11, pp. $\frac{2752-27}{63}, \frac{79}{(199) .}$

46. Chu, T. Y. J., et al. , Characterization and Reuse of Ash Pond Effluents in Coal-Fired Power Plants, presented at the 49th Annual Water Pollution Control Federation Conference, Minneapolis, MN, (1976).

47. Federal Register, Vo1. 41, No. 231, pp. 52780-86, December 1, 1976.

48. Draft Environmental Impact Statement, Memphis, Light, Gas and Water Division, Industrial Fuel Gas Demonstration Project, DOE/EIS-0071-D, U.S. DOE, October 1980. 


\section{SECTION 10 - ADDITIONAL BIBLIOGRAPHY}

1. Gold, H. and D. J. Goldslein, Water Related Environmental Effects in Fuel Conversion, Summary Volume, FE-2445-1 (Vol 1), Water Purification Associates (WPA), Cambridge, MA.

2. Gold, H., D. J. Goldstein, Water Related Environmental Effects in Fuel Conversion, Appendix Volume, FE-2445-1 (Vol 2), Water Purification Associates (WPA), Cambridge, MA.

3. Environmental Assessment, Gasification Combined Cycle Test Facility, Powerton Station, Pekin, IL. GAI Report No. 1919, for U.S. Energy Research and Development Administration, (1976).

4. Loran, B. I., and J. B. O'Hara, "A Clean Coal Conversion Technology", Environmental Science \& Technology, Vol. 12, No. 12, pp. 1258-1263, (1978).

5. Talty, J. T., "Assessing Coal Conversion Processes", Environmental Science \& Technology, Vol. 12, No. 8, pp. 890-894, (1978).

6. Stover, E. L., and N. K. Chung, "Petroleum Processing and Coal Conversion Wastes", Journal Water Pollution Control Federation, Vol. 51, No. 6, pp. 1393-1398, (1979).

7. Massey, M. J., R. W. Dunlap, and R. G. Luthy, Environmental Assessment in the ERDA Coal Gasification Development Program, progress report for the period of July 1976 - December 1976. Prepared for U.S. Energy Research and Development Administration under Contract No. E(49-18)-2496 by Environmental Studies Institute, Carnegie-Mellon University, Pittsburgh, PA, (1977).

8. Maruvama, T., S. A. Hannah and J. M. Cohen, "Metal Removal by Physical and Chemical Treatment Processes", Journal Water Pollution Control Federation, Vol. 47, No. 5, pp. 962-975, $(1 \overline{975})$.

9. National Institute for Occupational Safety and Health, Criteria for a Recommended Standard - Occupational Exposures in Coal Gasification Plants, DHEW (NIOSH) Publicátion No. 78-191, (1978).

10. Attari, A., M. Mensinger, and J. Pau, Initial Environmental Test Plan for Source Assessment of Coal Gasification, Institute of Gas Technology, Chicago, Illinois, EPA-600/2-76-259, PB-261916, (1976).

11. Salk, M. S., et. al., Environmental Monitoring Handbook for Coal Conversion Facilities, ORNL-5319, (1977).

12. Massey, M. J., and D. V. Nakles, ERDA's Coal Gasification Environmental Assessment Program: A Status Report, present ed at the 9th Synthet ic Pipeline Gas Symposium, Chicago, IL, October 31 - November 2, 1977. 
13. Programmatic Environmental Assessment for Pipeline Gas Demonstration Plants, Contract No. W-7405-eng-26, prepared by Fossil Energy Environmental

Project Environmental Impact Section, Energy Division, Oak Ridge National Laboratory (1977).

14. White, P. C., R. L. Zahradnik, Coal Gasification, Quarterly Report, July September, 1976, ERDA, Washington, D.C.

15. Environmental Development Plan (EDP), Coal Gasification Program, FY1977, DOE/EDP-0013, U.S. Department of Energy (1978).

16. Massey, M. J., Coal Based Energy Resources, Carnegie-Mellon University, Pittsburgh, PA.

17. Datta, R. S., Characterization of the Chemical Comminution of Coal, 3rd Quarterly Report, April-June $1 \overline{97}, \overline{F E-2520-3}$, by Syracuse Research Corp. for U.S. Dcpartment of Energy, (1977).

18. Jones, D. C., et al., Monitoring Environmental Impacts of the Coal and 0il Shale Undustry: R RD Needs, EPA-600/7-77-015, PB-266 $292, \frac{1977}{\text {. }}$

19. Proceeding of the 5 th Underground Coal Conversion Symposium, Alexandria, VA, June 18-21, 1979, CONF. NO: 790630, U.S. Department of Energy, (1979).

20. U.S. Environmental Protection Agency, Environmental Review of Synthetic Fuels, Vol. 3, No. 1, (1980).

21. Massey, M. J., and R. W. Dunlap, "Environmental Assessment in Coal Gasification Processing", 8th Synthet ic Pipeline Gas Symposium, Ramada, O'Hare Inn, October 18-20, 1976, American Gas Association Cat. N0: L51176.

22. 01 dham, R. G., and R. G. Wetherold, Assessment, Selection and Development of Procedures for Determining the Environmental Acceptability of Synthetic Fuel Plants Based on Coal, FE-1795-3 (Part 1), for U.S. Department of Energy by Radian Corp., (1977).

23. Gold, H., D. Goldstein, F. Seufert, and K. Van Wormer, Waste Disposal, Cooling and Related Environmental Impacts, Associated with Synthetic Fuel Plant Siting and Design Criteria, 1st Quarterly Report for August 8 -

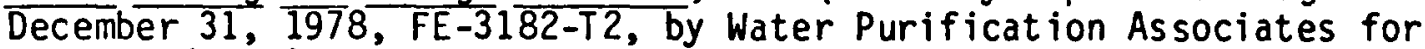
FE /DOE, (1978).

24. Goldstein, D. J., and F. B. Seufert, Waste Disposal, Cooling and Related Environmental Impacts Associated with Synthetic Fuel Plant Siting and Design Criteria, Part 1: Cooling Water Consumption Addendum to First Quarterly Report, FE-3182-T1 by WPA, Cambridge, MA, for U.S. Department of Energy, (1978). 
25. Engineer, Design, Construct, Test, and Evaluate A Pressurized Fluidized Bed Pilot Plant Using High Sulfur Coal for Production of Electric Power, Phase 1: Preliminary Engineering, Task 4: Environment a T Assessment, FE-1726-31A by Curt iss-Wright Corp., Power Systems Division, NJ, for U.S. Department of Energy.

26. Somerville, M. H., et. al., An Environmental Assessment of a Proposed 250 MM scfd Dry Ash Lurgi Coal Gasification FaciTity Located in Dunn County, North Dakota, Vo1. VI, Trace Elements: Overburden, Plant Effluents, and Biological Availability, University of North Dakota, Engineering Experiment Station Bulletin \#76-12-EES-01, (1976).

27. Rogers, S. E., et. al., Environmental Assessment of Coal Cleaning Processes: Homer City Power Complex Testing, EPA-600/7-79-073f, (1979).

28. Establishment of Environmental Baseline Condition, U.S. Energy Research and Development Administration.

29. Rausa, G. J., Environmental Research Related to Fossil Fuel Conversion, Office of Energy, Minerals \& Industry, U.S. Environmental Protection Agency, Washington, DC.

30. Environmental Analysis of Synthetic Liquid Fuels, Assistant Secretary for Environment, office of Technology Impacts, U.S. Department of Energy, (1979).

31. Emerson, D. B., Liquefaction Environmental Assessment, Hittman Associates, Inc., Columbia, MD, (1977).

32. Rolan, R. G., The Design and Implementation of an Environmental Monitoring Program for ERDA Fossil Fuel Facilities, Task Summary Report III, FE-2495-6, prepared for Energy Research and Development Administration by Dalton.Dalton - Little-Newport, Cleveland, OH, (1977).

33. NTISearch, Activated Carbon, Part 1, Waste Water Treatment, Vo1. 2, NTIS/PS-78/0626, Nat ional Technic il Information Service (1978).

34. NTISearch, Activated Carbon, Part 1, Waste Water Treatment, Vol. 1, NTIS/PS-78/0625, (1978).

35. NTISearch, Activated Carbon, Part 2, 0ther Uses, Vo1. 1, NTIS/PS-78/0627, National Technical Information Service, (1978).

36. Massey, M. J., et al., Environmental Assessment in the ERDA Coal Gasification Development Program, 1st Annual Report, JuTy $\frac{176}{\mathrm{Ju} T y} \frac{777}{7 \mathrm{FE}-2496-17}$, prepared for U.S. Department of Energy by Environnental Studies Institute, Carnegie-Mellon University, Pittsburgh, (1978).

37. Rolan, R. G., Guidelines for Multimedia Environmental Monitoring of Department of Energy Fossil Energy RD\&D Facilities, Vol. I, prepared for U.S. Department of Fnergy by Dalton-Dalton-Little. Newport, Cleveland, $\mathrm{OH}$, (1978). 
38. Difulgentiz, R. A., Phase I: The Pipeline Gas Demonstration Plant Coal Fines Briquetting Study, FE-2542-11, for U.S. Department of Energy by CONOCO Company.

39. Phase I: The Pipeline Gas Demonstration Plant Design and Evaluation of Commercial Plant, Vol. 4, Environmental Assessment \& Site Requirements, FE-2542-10 (VoT. 4), for U.S. Department of Energy by CONOCO.

40. Rolan, R. G., Guidel ines for Mult imedia Environmental Monitoring of Department of Energy Fossil Fuel RD\&D Facilities, Vol. II, prepared for U.S. Department of Energy by Dalton-Dalton-Little-Newport, (1978).

41. Information from ERDA, Reference Information, Special Issue, U.S. Energy Research and Development Administration, Washington, DC, (1977).

42. 1978 Proceedings - Refining Department, American Petroleum Institutc 43rd Midyear Meeting, May 8-11, 1978, Toronto, Ontario, Canada, Vol. 57, American Petroleum Institute, Washington, DC, 20037.

43. W. B. Watson, and G. J. Leaman, Jr., Phase 1: The Pipeline Gas Demonstration Plant, Quarterly Technical Progress Report for July 1 - September 30, 1979, FE-2542-24, prepared for U.S. Department of Energy by CONOCO Inc., Stamford, CN, (1979).

44. Sawyer, C. N. and P. L. McCarty, Chemistry for Sanitary Engineers, Second Edition, N.Y. McGraw-Hill, (1967).

45. Hughte, E. E., et al., Control of Environmental Impacts from Advanced Energy Sources, EPA-600/2-74-002, PB 239459 , (1974).

46. Goldstein, D. J., et al., Waste Disposal, Cooling and Related Environmental Impacts Associated with Synthet ic Fuel flant siting and Design Criteria, $\mathrm{FE}-3182-\mathrm{T} 3$, for DOE by WPA, Cambridge, MA, (1979).

47. Seward, W. H., J. R. Hollis, et al., A Survey of Environmental Control Technologies for Industrial Coal Use, ANL/ECT-8, Argonne National Lab., (1978).

50. Kalfadelis, C. D., et al., Evaluation of Pollution Control in Fossil Fuel Conversion Processes. Analyt ic al Test Plan, EPA-650/2-74-009-1, $\overline{P G-2} 49845,(1975)$.

51. Bloyd, C. N. and E. S. Rubin, "A Methodology for Assessing Cross-Media Environmental Impacts of Coal Conversion Plants", Proceeding of the 2nd Pacific Chemical Engineering Congress, Vol. 11, (1977).

52. Jahnig, C. E. and R. R. Bertand, Environmental Aspects of Coal Gasification, CEP 72, pp. 51-56, (1976).

53. Murray, C.F. and M. Ghassemi, High-Btu Gasification Environmental Assessment - Work Status and Plan, TRW Inc., Redondo Beach, California. 
544. Ghassemi, M. and C. Murray, Environmental Assessment of High-Btu Gasification: Annual Report, $\overline{E P A-600 / 7-78-025, P B ~ 27817} \overline{5},(1978)$.

55. Ghassemi, M. et al., Environmental Assessment Data Base for High-Btu Gasification Technology: Vol. I, Technical Discussion EPA-600/7-78186a, (1978).

56. ___ Vo1. II. Appendices A, B, and C, EPA-600/7-78-186b, (1978).

57. __ Vol. III: Appendices D, E, \& F, EPA-600/7-78-186c, (1978).

58. Page, G. C., Environmental Assessment: Source Test and Evaluation Report Chapman Low Btu Gasification, EPA-600-7/78-202, PB $\overline{289} 940,(1978)$.

59. Cavanaugh, E. C., W. E. Corbett, and G. C. Page, Environmental Assessment Data Base for Low/Medium-Btu Gasification Technology: Vol. 1 Technical Discussion, EPA-600/7-77-125a, (1977).

60. ___ Vo1. II. Appendices A-F, EPA-600/7-77-125b, (1977).

61. Robson, F. L. and W. A. Blecher, Combined-Cycle Power Systems Burning Low-Btu Gas, United Technologies Research Center, East Hartford, Conn.

62. Bombaugh, K. J., A Non-Site Specific Test Plan, Radian Corp., Austin, Texas.

63. Corbett, W. E., Low-Btu Gasification-Environmental Assessment, Radian Corp., Austin, Texas, (1979).

64. Best, C. N. et al., Hygas Demonstration Plant Project, Process Baseline Report Initial Process Trade-Off Studies Environmental Inventory Report, Revision 0, for U. S. Department of Energy by PROCON Inc., Des Plaines, Illinois, $(1978)$.

65. Anastasia, L. J. et al ., Environmental Assessment Program for the Hygas Process, presented at the U.S. Environmental Protection Agency Symposium on Process Measurements for Environmental Assessment, Atlanta, Georgla, Feb. 12-15, 1978.

66. Anastasia, L. J. et al. Environmental Characterization of the Hygas Process, Presented at the 6th National Conference on Energy and Environment, Pittsburgh, PA, May 21-24, 1979.

67. Massey, M. J. et al., Status of C-MU Environmental Activities at the Hygas Pilot Plant, 2nd Quarterly Report, FE-2496-8, for U.S. Departinent of Energy by Environmental Studies Institute, Carnegie-Mellon University, Pittsburgh, PA, (1978).

68. Chase, Victor D., "Rusty Iron May Be the Key to Cheaper Gas from Coal", Popular Science, pp. 91-94, (1977). 
69. Pipeline Gas by Hydrogasification, (Hygas Process) Institute of Gas Technol ogy, Chicago, 111 .

70. Environmental Assessment of the Hygas Process, FE-2433-16, for U.S. Department of Energy by Institute of Gas Technology, Chicago, III., (1978).

71. Massey, M. J. et al., Analysis of Coal Wastewater Analytical Methods: A Case Study of the Hygas Pilot PIant, FE-2496-3, for U.S. Department of Energy by Carnegie-Mellon University, Pittsburgh, PA, (1978).

72. Koblin, A. H. and M. J. Massey, Prel iminary Investigation: Time Variability of the Pretreater Condensate Composition at the Hygas Pilot Plant, FE-2496-10, for Department of Energy by Carnegie-Mellon University, Pit.t.shurgh, PA, (1978).

73. Paulson, L. E., H. H. Schobert and R. C. Ellman, "Sampling, Analys is, and Characterization of Effluents from the Grand Forks Energy Research Center's Slagging Fixed Bed Gasifier", Symposium on Environmental Aspects of Fuel Processing, American Chemical Society, March 12-17, 1978, pp. 107-118.

74. Anastasia, L. J. et al., Environmental Characterization of Hygas Pilot Plant Water Streams, presented at the 87th National Meeting of the American Institute of Chemical Engineers, Boston, MA, August 19-22, 1979.

75. Dunlap, R. A. and M. J. Massey, Assessment of Environmental Characterization Activities for the Slagging Fixed-Bed Gasification Facility at the Grand Forks Energy Research Center, for U.S. Department of Energy by CarnegieMellon University, FE-2496-12, (1978).

76. Sinor, J. E., Evaluation of Background Data Relating to New Source Performance Standards for Lurgi Gasification, EPA-600/7-77-057, PB269557, (1977).

77. Control of Emissions from Lurgí Coal Gastfication Plants, U.S. Environmental Protect ion Agency, EPA-450/2-78-012, (1978).

78. Beychok, M. R., New Source Performance Guidelines for Lurgi Coal Gasification Plants, irvine, CA.

79. Shaw, H. and E. M. Magee, Fossil Fuel Conversion Processes: Gasification; Section I: Lurgi Process, EPA-650/2-74-009-C, PB 237694, (1974).

80. Ghassemi, M., K. Crawford and S. Quinlivan, Environmental Assessment Report: Lurgi Coal Gasification Systems for SNG, EPA-60077-79-120, PB 298109, (1979).

81. Schobert, H. H., et al., Carbonization Reactions in the Grand Forks FixedBed Slagging Gasifier, American Chemical Society, Division of Fuel

Chemistry, Vo1. 23, No. 3, pp. 136-141, (1978). 
82. Somervile, M. H., et al., A Comparative Study of Effluents and Their Control from Four Dry Ash Lurgi Gasification Plants, Execut ive Summary, C00-4035-2 (Section A), for U.S. Department of Energy by University of North Dakota, (1978).

83. Kornosky, R. M., et al., "Gasification of Iowa Coal in the Synthane PDU Gasifier", Proceedings of the 173 RD National Meeting, American Chemical Society, March 21-25, 1977 .

84. Massey, M. J., et al, "Effluents from Synthane Gasification of Lignite, Coal Processing Technology, Volume 3, American Institute of Chemical Engineers, N.Y., N.Y., (1977).

85. Weiss, A. J., "Synthane Process Ready for Scale-Up", Hydrocarbon Processing, pp. 125-129, (1978).

86. $\mathrm{CO}_{2}$ Acceptor Process Gasification Pilot Plant, Environmental Characterization, Final Report, Vol. II, Book 2 of 3, Appendices A\&B, FE-1734-44 (Vol. II), (BOok 2), CONOCO Coal Development Company and Radian Corporation, (1978).

87. Book 3 of 3, Appendices C through G, FE-1734-44 (Vol. II) (Book 3),

88. Dunlap, R. W., et al., Characterization of Effluents from the $\mathrm{CO}_{2}$-Acceptor Coal Gasification Process, FE-2496-5, for U.S. Department of Energy by Carnegie-Mellon University, (1978).

89. Nankles, D. V., D. F. Hunter, and M. J. Massey, Test Plan for the Environmental Characterization of the Bi-Gas Pilot Plant, FE-2496-22, for U.S. Department of Energy by Carnegie-Mellon University, (1978).

90. Nakles, D. V. and M. J. Massey, Gasification Process/Environmental Characterization from Pilot Plant Data, presented at the Environmental. Aspect of Fuel Conversion Technology, III Symposium, Hollywod, FL, September 12, 1977.

91. Koblin, A. H. and M. J. Massey, Influence of the Variability on the Design of Sampling Strategies for Coal Gasification Wastewaters, Carnegie-Mellon University, Pittsburgh, $P A$.

92. Massey, M. J., et al., Characterization of Effluents from the Hygas and $\mathrm{CO}_{2}$ - Acceptor Pilot plants, Interim Report, July-September 1976, FE-2496-1, for U.S. Energy Research and Development Administration by. Carnegie-Mellon University.

93. Attari, A., et al., Fate of Trace Constituents of Coal During Gasification (Part II), presented at the 169th Meeting, Americal Chemical Society, Division of Fuel Chemistry, Philadelphia, PA, April 6-11, 1975.

94. Somerville, M. J., et al., Trace Elements: Analysis of Their Potential Impact From A Coal Gasification Facility, Bulletin \#77-05-EES-01, University of North Dakota, (1977). 
95. Luthy, R. J., et al, Wastewater Analysis in the ERDA Coal Gasification Environmental Assessment Program, Third Quarterly Report, FE-2496-11, for Department of Energy by Carnegie-Mellon University, (1978).

96. Singer, P. C., et al., Composition and Biodegradability of Organics in Coal Conversion Wastewaters, presented at 3rd Syposium on Environmental Aspects of Fuel Conversion Technology, Sponsored by Environmental Protection Agency, (1977).

97. Luthy, R. G. and S. G. Bruce, Jr., "Kinetics of Reaction of Cyanide and Reduced Sulfur Species in Aqueous Solution", Environmental Science and Technology, Vol. 13, No. 12, pp. 1481-87, (1979).

98. Luthy, R. G., et al., "Cyanide and Thiocyanate in Coal Gasification Wastewaters", Journal of the Water Pollution Control Federation, Vol. 51. No. 9, pp. 2267-82, (1979).

99. Brookman, G. T. and W. A. Wade III, Measurement of Non-Point Sources from a Coal-Fired Utility and the Impact on Receiving Waters, EPA-600/2-77-199, (1977).

100. Process, Procedures, and Methods to Control Pollution from Mining Activities, U.S. Environmental Protection Agency, EPA-430/9-73-011, (1973).

101. Environmental Control Implications of Generating Electric Power from Coal, 1977 Technology Status Report, Appendix A, Part 2, Coal Preparation and Cleaning Assessment Study Appendix, ANL/ECT-3, Appendix A, Part 2, for U.S. Department of Energy by Argonne National Laboratories, IL.

102. Van Hook, R. I. and W. D. Shults (Editors), Effects of Trace Contaminants from Coal Combustion, ERDA- $/ 7-64$, Proceedings of a Wurkshop, August 2-6, 1976, Knoxville, TN.

103. Wewerka, E. M., et al., Trace Element Characterization and Removal/Recovery from Coal and Coal Wastes, LA-7117-PR, Progress Report, April 1-June 30, 1977, Los Alamos Scientific Laboratory, (1978).

104. Wewerka, E. M., et al., Trace Element Characterization and Reiluval/Recovery from Coal and Coal Wastes, LA-6933-PR. Progress Report, October 1-December 31, 1977, Los Alamos Scientific Laboratory, (1977).

105. Wewerka, E. M., et al., Trace Element Characterization and Removal/Recovery from Coal and Coal Wastes, LA-7104-PR, Progress Report, January 1-March 31, 1977, Los Alamos Scientific Laboratory, (1978).

106. Lee, S. H. D., et al., A Study of the Volatility of Minor and Trace Elements in Illinois Coal, ANL/CEN/FE-77-4, for U.S. Departinent of Energy by Argonne National Laboratory, IL.

107. Wewerka, E. M. and J. M. Williams, Trace Elements Characterization of Coal Wastes - Ist Annual Report, Los.Alamos Scient if ic. Laboratory, EPA-600/7-78-028, (1978). 
108. Henrisch, G. W. and G. J. Leaman, Jr., Phase I: The Pipeline Gas Demonstration Plant, Analysis of Coal, By-Products and Waste Waters from the Technical Support Program, FE-2542-23, for U.S. Department of Energy by CONOCO Inc., $(1979)$.

109. Luthy, R. G. and M. J. Pochan, Determination of Cyanide Levels in Hygas Wastewater, FE-2496-36, for U.S. Department of Energy by Carnegie-MelTon University, (1978).

110. Koblin, A. H., et al., Effluent Data Analys is Computer Program, FE-2496-14, for U.S. Department of Energy by Carnegie-Mellon University, (1978).

111. Luthy, R. G., Manual of Methods: Preservation and Analysis of Coal Gasification Wastewaters, FE-2496-16, U.S. Department of Energy by Carnegie-Melion University, (1978).

112. Dzierlenga, P. S., et al., "Sampling and Analysis of Synthet ic Fuel Processes", Environmental Science and Technology, Vol. 12, p. 288, (1979).

113. Cleland, J. G., A Program for Parametric Evaluation of Pollutants from a Laboratory Gasifier, Research Triangle Institute, Research Triangle Park, NC.

114. Kingsbury, G. L., Development of Multimedia Environmental Goal's (MEG's) for Pollutants from Fuel Conversion Process, Research Triangle Institute, Research Triangle Park, NC.

115. Kuhn, J. K., et al., Volatility of Coal and Its By-Products, presented at the 3rd Annual EPA Symposium on Environment al Aspects of Fuel Conversion Technology, Hollywood, FL, (1977).

116. Loran, B. I. and J. B. O'Hara, Specific Environmental Aspects of FischerTropsch Coal Conversion Technology, presented at the 3rd Annual EPA Symposium on Environment at Aspects of Fuel Conversion Technology, Hollywood, FL, (1977).

117. Pitt, W. W. and R. L. Jolley, Characterization of Organics in Aqueous Streams of Coal Conversion Processes, presented at the 2nd Pacific Area Chemical Engineering Conference, Denver, CO, (1977).

118. Koblin, A. H., et al., Exploratory Analysis of Variations in Aqueous Gasification Effluent Characteristics with Time, FE-2496-2, for U.S. Department of Energy by Carnegie-Mellon University, (1978).

119. Anastasia, L. J., et al., Environmental Characterization of Hygas Pilot Plant Water Streams, presented at the 87 th National Meeting of the American Institute of Chemical Engineer, Boston, MA, (1979).

120. Ray, S. S. and F. G. Parker, Characterization of Ash from Coal-Fired Power Plants, EPA-600/7-77-100 for Industrial Environmental Research Laboratory by Tennessee Valley Authority, (1977). 
121. Page, G. C., Fate of Pollutants in Industrial Gasifiers, Radian Corporation, Austin, TX.

122. Griffin, R. A., et al., Solubility and Toxicity of Potential Pollutants in Solid Coal Wastes, Illinois State Geological Survey, Urbana, IL.

123. Thoem, T. L., Coal Fired Power Plant Trace Element Study, Office of Energy Activities, U.S. Environinental Protect ion Agency, Denver, CO.

124. Williams, J. M., et al., Trace Element Distribution in Several Coal Conversion Processes, LA-7100-MS, Los Alamos Scientific Laboratory, (1978).

125. Sparacino, C. M., et al., Analytical Techniques and Analys is of Coal Tars, Waters, and Gases, Research Triangle Institute, Research Triangle P̧ạk, NC..

126. Koralek, C. S. and V. Bruce May, Flue Gas Sampling During the Combustion of Solvent Refined Coal in a Utflity Builer, Hittman As sociates, Inc., Columbia, MD.

127. Parsons, W. A. and W. Nolde, "Applicability of Coke Plant Water Treatment Technol ogy to Coal Gasification", Proceedings of the Environmental Aspects of Fuel Conversion Technology Symposium, III, Hollywood, FL, September 1977, EPA-600/7-78-063, (1978).

128. Hal I, H. J., G. M. Varga, and E. M. Magee, "Distribution of Trace Elements in Coal", Symposium Proceedings Environmental Aspects of Fuel Conversion Technology, St. Louis, MO, $(1974)$.

129. Gluskoter, H. J., et al., "An Investigation of Trace Elements in Coal", Symposium Proceedings: Environmental Aspects of Fuel Conversiun Techiology, II, Hollywood, FL, (1975).

130. Murphy, J., Determination of Mercury in Coals by Peroxide Digestion and Cold Vapor Atomic Absorption Spectrophotometry, Atomic Absorption Newsletter, Vol. 14, No. 6, p. 151, (1975).

131. Weber, W. J., Physicochemical Processes for Water Uuality Control, W1leyInterscience, (1972).

132. Sundstrom, D. W. and H. E. Klei, Wastewater Treatment, Prentice-Hall, (1979).

133. Identification of Potentially Hazardous Planl Process Streams and Restdue Streams Under Section 3001 of P.L. 94-5800, Resource Conservation and Recovery Act of 1976, ICGG and CONOCO Pipeline Gas Demo. Plants, DOE/ET/03117, TR-79/006-01, UOP/SDC, (1979).

134. Nakles, D. V., Characterization of Hydrogen Cyanide Production in Coal Gasification, FE-2496-29, for U.S. Department of Energy by Carnegie-Mellon University, (1979). 
135. Luthy, R. G., et al., Identification and Reactions of Cyanide and Thiocyanate in Coal Gasification Wastewaters, FE-2496-23, for U.S. Department of Energy by Carnegie-Mellon University, (1978).

136. Pellizzari, E. D., Identification of Components of Energy-Related Wastes and Effluents, EPA-600/7-78-004, Research Triangle Institute (1978).

137. Neufield, R. D., P. Lubon and L. Mattson, Aerol ic Bio-Oxidation of Thiocyanates: Development of Design Parameters, for U.S. Department of Energy by University of Pittsburgh, Pittsburgh, PA, (1979).

138. Lebowitz, H., et al., Potentially Hazardous Emissions from the Extraction and Processing of Coal and 0il, EPA-650/2-75-038, Bat telTe Columbus Laboratories, (1975).

139. Klein, J. A. and R. E. Barker, Assessment of Environmental Control Technology for Hydrocarbonization, Proceedings - The 2 nd Pacific Chemical Engineering Congress, Vol. II, p.1036-43, (1977).

140. Koppenaal, D. W., Trace Element Studies on Coal Gasification Process Streams, Ph.D. Dissertation, University of Missouri at Columbia, MO, (1978).

141. Sharkey, A. G. Jr., et al., Mass Spectrometric Analysis of Streams from Coal Gasification and Liquefaction Processes, PERC/RI-75/5, Pittsburgh Energy Research Center, (1975).

142. Forney, A. J., et al., Analysis of Tars, Chars, Gases, and Water Found in Effluents from the Synthane Process, for U.S. Department of Energy by Pittsburgh Energy Research Center, (1974).

143. Neufeld, R. D. and T. Valiknac, "Inhibition of Phenol Biodegradation by. Thiocyanate", Journal of the Water Pollution Control Federation, Vol. 51', No. 9, pp. 2283-2291, (1979).

144. Neufeld, R. D. and T. Valiknac, Bio-oxidation of Aqueous Cyanogens Typical of Synthane Gasifier By-product Water, Progress Report, Sept-Nov 1977 , Co0-450L-1, University of Pittsburgh, (1977).

145. Kominek, E. G., Future Needs and the Impact on the Water and Waste Equipment Manufacturing Industry Due to the Use of Synthetic Fuels, presented at the Environinental Aspects of fuel Conversion Technologies Symposium, Hollywood, FL, (1977).

146. Shearer, R. E. and W. A. Everson, Effect of Antibacterial Agents on Mine Drainage, for Commonwealth of Pennsylvania by MSA Research Corp. , Evans City, PA, (1969).

147. Wei, I. W. and D. J. Goldstein, Biological Treatment of Coal Conversion Condensates, presented at the 3rd Symposium on Environmental Aspects of Fuel Convers ion Technology, Hollywood, FL, (1977). 
148. Mihos, P., "Water Reuse at a Coal Gasification Plant", Chemical Engineering Progress, Vol. 71, No. 6, pp. 99-104, (1975).

149. Seufert, F. B., et al., Conceptual Designs for Water Treatment in Demonstration Plants, II, Appendix - Design Procedures, FE-2635-T2, for U.S. Department of Energy by Water Purification Association, (1979).

150. Rubin, E. S., et al., Cross Media Environmental Impacts of Coal-to-Electric Energy Systems, presented at 3rd EPA Symposium on Environmental Aspects of Fuel Conversion Technology, Hollywood, FL, (1977).

151. McNeese, J. A. and D. B. Wilson, Utilization of Brackish Water in Coal Gasification, Technical Completion Report, WRRl Report No. 063, New Mexico Water Resources Research Institute, (1976).

152. Fisher, J. F. and G. R. Peterson, Control of Hydrocarbon and Carbon Monoxide Emissions in the Tail Gases from Coal Gasification Facilities, ORNL/TM-6229, Oak Ridge National Laboratory, (1978).

153. Slamoudis, V. C. and R. G. Luthy, Biological Removal of Organic Constituents in Quench Water from a siagging, Fixed-Bed Coal-Gasification Pilot Plant, ANL/PAG-1, Argonne National Laboratory, Il linois, (1980).

154. Biological Removal of Organic Constituents in Quench Waters from High-Btu Coal-Gasification Pilot Plants, ANL/PAG-2, Argonne National Laboratory, IlTinois, (1980).

155. Seward, W. H., Process Alternatives for Sulfur Management in Coal Gasification Plants, presented at the 9th synthetic Pipeline Gas Symposium, (1977).

156. Kumura, S. G., Permselective Membranes for Acid Gas Scrubbing from Coal Gas, present ed at 9th Synthetic Pipeline Gas Symposium, (1977).

157. Chu, T. Y. J., et al., Removal of Complex Copper-Ammonia Ions from Aqueous Wastes with Fly Ash, presented at the 32 nd Annual Purdue Industrial Waste Conference, Purdue University, (1977).

158. Evaluation of Additives for Improving Scrubber Sludge Characteristics for Disposal, presented at the 32nd Annual Purdue Industrial Waste Conference, Purdue University, (1977).

159. Moore, A. S., Jr., Cleaning Producer Gas from MERC Gasifier.

160. Bostwick, L. E., Control Technology Development for Fuel Conversion System Wastes, Pul lman Kellogg, Houston, Texas, (1977).

161. Klemetson, S. L., Treatment of Phenolic Wastes, presented at EPA Environmental Aspects of Fuel Conversion Technology III Symposium, Hollywood, $\mathrm{FL},(1977)$. 
162. Wei, I. W. and D. J. Goldstein, Biological Treatment of Coal Conversion Condensates, presented at the 3rd Symposium on Environmental Aspects of Fuel Conversion Technology, Hollywood, FL, (1977).

163. Parsons, W. A. and W. Nolde, Applicability of Coke Plant Water Treatment Technology to Coal Gasification, presented at the EPA Environmental Aspects of Fuel Conversion Technology Symposium, Hollywood, FL, (1977).

164. Conceptual Designs for Water Treatment in Coal Conversion Plants, Report on Contract EF-77-C-01-2035 by Water Purificat ion As sociates, Cambridge, Massachusetts, (1978).

165. Kominek, E. G., Wastewater Treatment for the Coal Gasification Industry, Institute of Gas Technology, Chicago, Iliinois, (1977).

166. Chu, T. Y. J., et al., Complete Reuse of Ash Pond Effluents in FossilFueled Power Plants, presented at the 68th Annual Meeting of the AICHE Symposium on Water Reuse in the Chemical Industry, Los Angeles, Calif., $(1975)$.

167. Treatment of Acid Mine Drainage, Program No. 14010 DEE, Contract No. 14-12-496, for U.S. Department of the Interior, by Horizons Inc., Cleveland, Ohio, (1970).

168. Hicks, R. E., et al., Wastewater Treatment in Coal Conversion, EPA-600/7-79-133, for U.S. Environment al Protection Agency by Water Purification Associates, (1979).

169. Klein, J. A., "Wastewater Treatment for Coal Conversion Plants," Proceedings, U.S. Department of Energy Environmental Control Symposium, Volume 1 of 3 . Plenary Session and Fossil Fuels, D0E/EV-0046 (Sept. 1979), Washington, D.C., (1978).

170. Beckner, J. L., Trace Element Composition and Disposal of Gasifier Ash, presented at the American Gas As sociation Conference, 0'Hare Inn, Chicago, Illinois, (1975).

171. Ferrel1, J. K., et al., A Coal Gasification and Gas Cleaning Test Facility, North Carolina State University, NC.

172. Stover, S. E. and F. D. Hoffert, Selection of Acid Gas Treating Processes for Coal Converter Outputs, Hydrocarbon Research, Inc., New Jersey.

173. NITSearch, Coke Oven Air and Water Pollution, NTIS/PS-78/0297, National Technical Information Service, (1978).

174. Gott, R. D., A Discussion and Review of the Development of Waste Water Treatment at the Climax Mine, Climax, Colorado, present ed at the 1977 American Mining Congress, San Francisco, California, (1977). 
175. Scott, C. D., et al., "A Tapered Fluidized-Bed Bioreactor for Treatment of Aqueous Effluents from Coal Conversion Processes", Symposium Proceedings: Environmental Aspects of Fuel Conversion Technology, II, Hollywood, $F L$, (1975).

176. Magee, E. M., Evaluation of Pollution Control in Fossil Fuel Conversion Processes. Final Report, EPA-600/2-76-101, Exxon Research and Engineering Company, (1976).

177. Parsons, W. A. and R. A. Ashworth, "Coal Conversion Process Wastewater Control", Symposium Proceedings: Environmental Aspects of Fuel Conversion Technology, II, Holiywood, FL, (1975).

178. Bonham, J. W. and W. T. Atkins, Process Comparison Effluent Treatments, Ammnnia Separation, Final Report, FE-2240-19, for U.S. Energy Research and Development Administration by C. F. Braun and Co., (1975).

179. Patel, J. G. and J. W. Loeding, "IGT U-Gas Process", Proceeding of the Clean Fuels from Coal Symposium II, sponsored by the Institute of Gas Technology, Chicago, Illinois, (1975).

180. Johnson, B. C., H. H. Schbert and M. M. Fegley, "The Grand Forks Slagging Gasifier", Volume IV, Coal Processing Technology, American Institute of Chemical Engineers, $(1 \overline{978})$.

181. Wilson, G. L., Effluent Treatment Aqueous Waste, Interim Report, FE-2240-9, for U.S. Department of Energy by C. F. Braun \& Co., (1977).

182. Witt, E. R. and W. J. Humphrey, Full Scale Anerobic Filter High Strength Wastes. presented at the Purdue Industrial Waste Conference, Purdue University, (1979).

183. Singer, P. C., et al., Assessment of Coal Conversion Wastewaters:

Characterization and Preliminary Biotreatability, EPA-600/7-78-181, for Industrial Environmental Research Laboratory by North Carolina University at Chapel Hill, NC, (1978).

184. Anderson, G. L., et al., "Ultrafiltration for Coal Gasification Plants", Chemical Engineering Progress, Vol. 4, No. 8, pp. 64-72, (1978).

185. Ultrafiltration for Coal Gasification Processes, presented at the 85 th American Institute of Chemical Engineering National Meeting, Phlladelphia, Pennsylvania, (1978).

186. Muela, C. A., Treatment of Wastewater from Coal Gasification Plants, presented at the 2nd Pacific Chemical Engineering Congress, Vol. II, pp. 1052-1057, (1977).

187. Koblin, A. H. and M. J. Massey, Influence of the Variability on the Design of Sampling Strategies for Coal Gasification Wastewaters, presented at the 2nd Pacific Chemicat Engineering Congress, Vol. II, p. 1044-1051, (1977). 
188. Parsons, W. A. and W. Nolde, "Water Treatment Needed in Gasification", The 0il \& Gas Journal, Pp. 157-158, January 29, 1979.

189. Pochąn, M. J., et al., Equipment and Strategy for Environmental Sampling of Complex Coal Gasification Process Streams, presented at the 14 th Intersociety Energy Conversion Engineering Conference, (1979).

190. Sack, W. A. and W. R. Bokey, Biological Treatment of Coal Gasification Wastewater, presented at the 33rd Purdue Industriat Waste Conference, May, 1978.

191. Yen, T. F., et al., Generalized Methodology of Synfuel Wastewater Treatment, presented at the Division of Environmental Chemistry, American Chemical. Society, Anaheim, California, (1978).

192. Jahnig, C. E., Evaluation of Pollution Control in Fossil Fuel Conversion Processes: Gasification, Section 8. Windker Process, EPA-650/2-74-009J, for Industrial Environment al Research Laboratory by Exxon Research and Engineering Company, (1975).

193. Singh, S. P. N., et al , Evaluation of Eight Environmental Control Systems

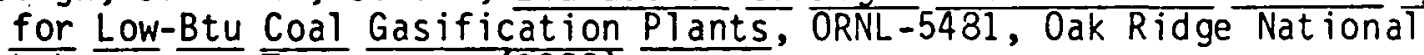
Laboratory, Tennessee, (1980).

194. Costs and Technical Characteristics of Environmental Control Processes for Low-Btu Coal Gasification Plants, ORNL-5425, 0ak Ridge National Laboratory, $(1980)$.

195. Klein, J. A., National Progress in Control of Wastewater from Coal Conversion Processes, presented at the Symposium on Potential Health and Environmental Effects of Synthetic Fossil Fuel Technologies, Gatlinburg, Tennessee, (1978).

196. Nakles, D. V., et al., Influence of Synthane Gasifier Conditions on Effluent and Product Gas Production, PERC-75/6, Pittsburgh Energy Research Center, $\overline{\text { Pitt sburgh, }} \overline{\text { PA, }}(1975)$.

197. Neufeld, R. D. and T. Valiknac, Preliminary Evaluation of the Biological Oxidation of Thiocyanates, Progress Report, Nov. 30, 1977 - Feb., 1978, C00-C502-2, for Pittsburgh Energy Research Center by University of Pittsburgh, (1978).

198. Anderson, G. L., Ozonation of High Levels of Phenol in Water, presented at the 68th Annual Meeting of the American Institute of Chenical Engineers, Los Angeles, CA, (1975).

199. Forney, A. J., et al., Trace Element and Major Component Balances Around the Synthane PDU Gasifier, PERC/TPR-75/1, Pitt sburgh Energy Research Center, Pittsburgh, PA, (1975).

200. Rolke, D. E., "Effluent Treatment with Particular Reference to Reuse of the Water", Chemsa, pp. 141-144, (1979). 
201. Ghassemi, M., et al., Applicability of Petroleum Refinery Control

Technologies to Coal Conversion, EPA-600/7-78-190, for U.S. Environmental

Protection Agency by TRW, Inc., (1978).

202. Phase 1: The Pipel ine Gas Demonstration Plant Environmental Report, for U.S. Department of Energy by CONOCO, Inc., (1980).

203. Berty, T. E. and J. M. Mae, "Environmental Aspects of the Wesco Coal Gasification Plant", Symposium Proceedings: Environmental Aspects of Fuel Conversion Technology, St. Louis, MO. (1974).

204. Steam: Its Generation and Use; Babcock \& Wilcox, (1972).

205. Wastewater Engineering, Metcalf \& Eddy Inc., McGraw-Hill, (1972).

206. Manahan, S. E., Environmental Chemistry, Second Ėdition, Willard Grant Press, (1975).

207. Kice, J. L. and E. N. Marvell, Modern Principles of Organic Chemistry, Macmillian, (1972).

208. Beychok, M. R., "Coal Gasification and the Phenosolvan Process", Proceedings: 168th National Meeting American Chemical Society, At lant ic City, NJ, (1974).

209. Industrial Fuel Gas Demonstration Plant Program: Demonstration Plant Process Design, for U.S. Department of Energy by Memphis Light, Gas, and Water Division.

210. Industrial Fuel Gas Demonstration Plant Program: Wastewater Treatment Design, for U.S. Department of Energy by Memphis Light, Gas, and Water Division.

211. Phase I: Pipeline Gas Demonstration Plant: Demonstration Plant Process Draft Design, for the U.S. Departinent of Energy by CONOCO Inc.

212. Walters, R.W., G.F. Vadja and R.G. Luthy, "Coal Gasification Wastewater Reuse". Proceedings - Water Reuse Symposium, Volume I, p. 522-543, (1979).

213. Webber, D. K. and D. E. Whittaker, Environmental Standards for Coal Conversion Processes. Vol. II. Selected State, Mexican and Canadian Regulations, EPA-600/7-79-231b, (1979).

214. Bostwick, L. E., et al., Coal Converston Cunitrol Technology, Vol. I, Environmental Regulations: Liquid Effluents, EPA-600/17-79-228a, (1979).

215. Sacks, M. E., Gasification Method, US Patent \# 3,966,634, (1976).

216. Model State Water Monitoring Program, U.S. EPA, 440/9-74-002, Office of Water and Hazardous Materials, Monitoring and Data Support Division, Washington, D.C. (June, 1975). 
217. Minimal Requirements for a Water Quality Assurance Program, U.S. EPA, EPA-440/9-75-010, Washington, D.C. (September, 1975).

218. Annual Book of ASTM Standards, Part 31, Water, Method D3370-76, ASTM, pp. 68-78, Philadelphis, Pa. (1978).

219. Standard Methods for the Examination of Water and Wastewater, 14th Edition, Part 105, American Public Health As sociation, pp. 38-45, Washington, D.C. (1976).

220. Handbook for Monitoring Industrial Wastewater, Chapter 6, U.S. EPA, Technology Transfer, pp. 6-1 through 6-28 (August, 1973).

221. Methods for the Chemical Analys is of Water and Wastes, Table 2, U.S. EPA, Environment al Monitoring and Support Laboratory, pp. viji-xii, June, 1974.

222. Guidelines Establishing Test Procedures for the Analysis of Pollutants, Federal Register, pp. 52780-52786 (December 1, 1976).

223. Quality Assurance Program for the Analyses of Chemical Constituents in Environmental Samples, U.S. EPA, Environmental Monitoring and Support Laboratory (March, 1978).

224. Handbook for Analytical Quality Control in Water and Wastewater Laboratories, U.S. EPA, Environmental Monitoring and Support Laboratory, June, 1972. 